


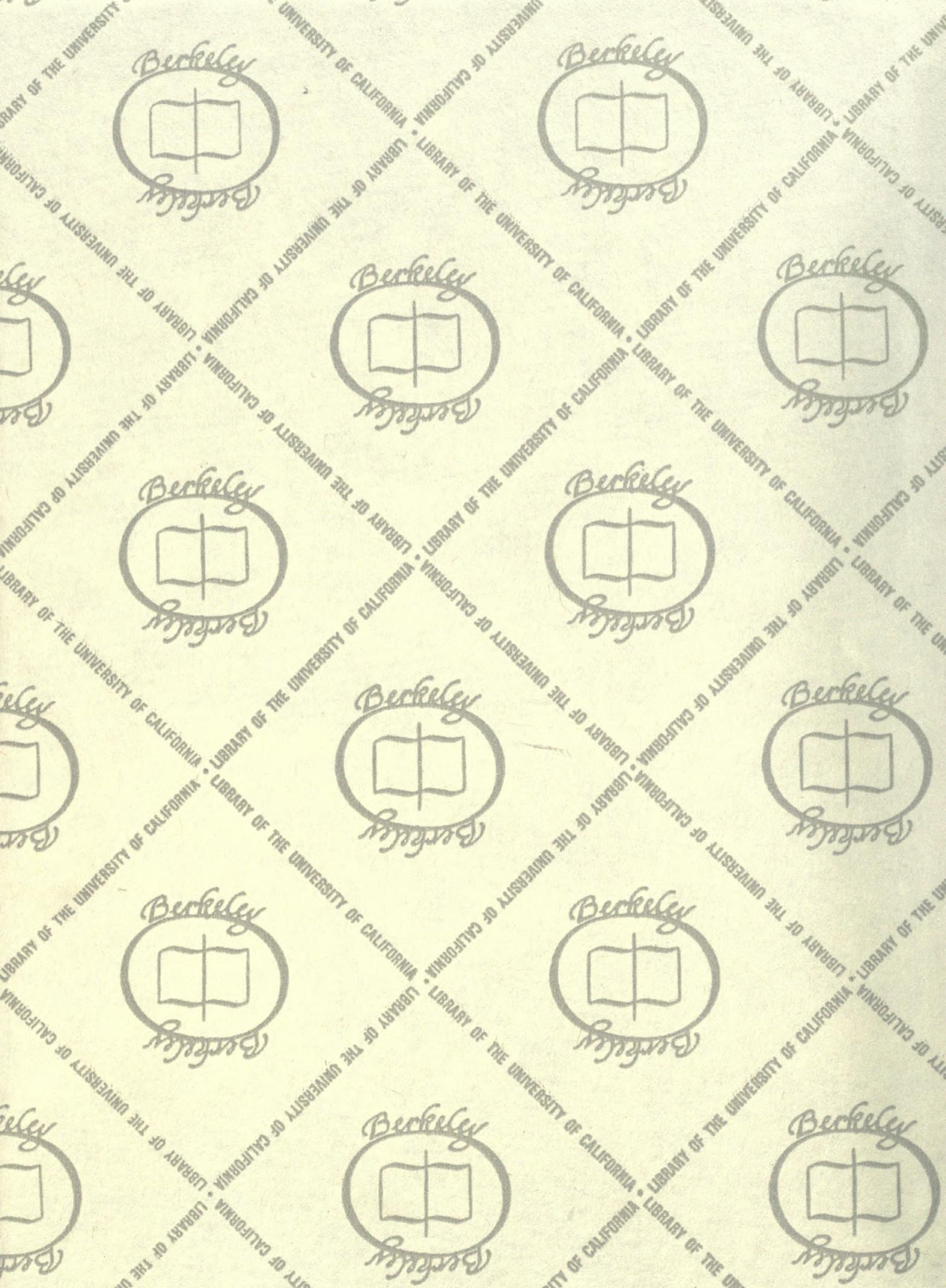






\title{
Library of Garvard antwergity.
}

\section{Bibliographical CONTRIBUTiOns.}

\author{
EDITED BY JUSTIN WINSOR, . \\ LIBRARIAN.
}

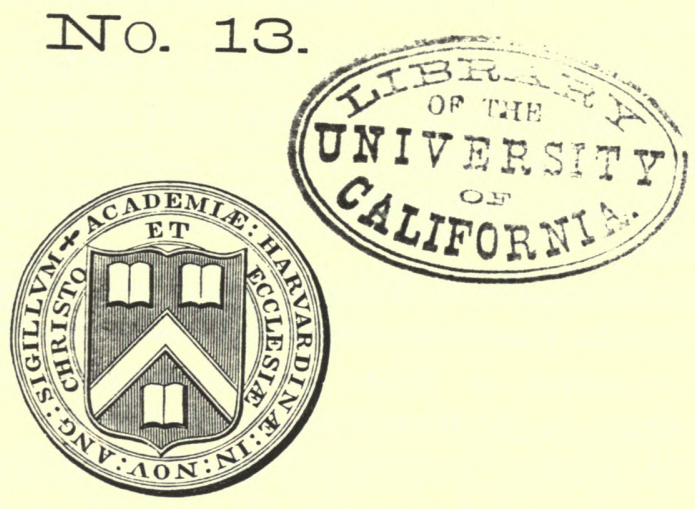

\section{A BIBLIOGRAPHY OF FOSSIL INSECTS.}

By SAMUEL H. SCUDDER.

REPUblished From the Bulletin of HaRvard University.

CAMBRIDGE, MASS. :

UNIVERSITY PRESS: JOHN WILSON AND SON. I 882. 


\section{Already issued or in preparation:}

A Star prefixed indicates they are not yet ready.

r. Edward S. Holden. Index-Catalogue of Books and Memoirs on the Transits of Mercury.

2. Justin Winsor. Shakespeare's Poems: a Bibliography of the Earlier Editions.

3. Charles Eliot Norton. Principal books relating to the Life and Works of Michelangelo, with Notes.

4. Justin Winsor. Pietas et Gratulatio. An Inquiry into the authorship of the several pieces.

5. List of Apparatus in different Laboratories of the United States, available for Scientific Researches involving Accurate Measurements.

6. The Collection of Books and Autographs, bequeathed to Harvard College Library, by the Honorable Charles Sumner.

*7. James M. Peirce. References in Analytic Geometry.

- *. Calendar of the Arthur Lee Manuscripts in Harvard College Library.

9. George Lincoln Goodale. The Floras of different countries.

io. Justin Winsor. Halliwelliana: a Bibliography of the Publications of James Orchard • Halliwell-Phillipps.

i i. Samuel H. Scudder. The Entomological Libraries of the United States.

12. A List of the Publications of Harvard University and its Officers, i870-I880.

I3. Samuel H. Scudder. A Bibliography of Fossil Insects.

14. William H. Tillinghast. Notes on the Historical Hydrography of the Handkerchief Shoal in the Bahamas.

I5. J. D. Whitney. List of American Authors in Geology and Palæontology.

*16. Richard Bliss, Jr. Classified Index to the Maps in Petermann's Geographische Mittheilungen. $1855^{-1} 88 \mathrm{r}$.

*i7. Justin Winsor. A List of the most useful Reference Books. 


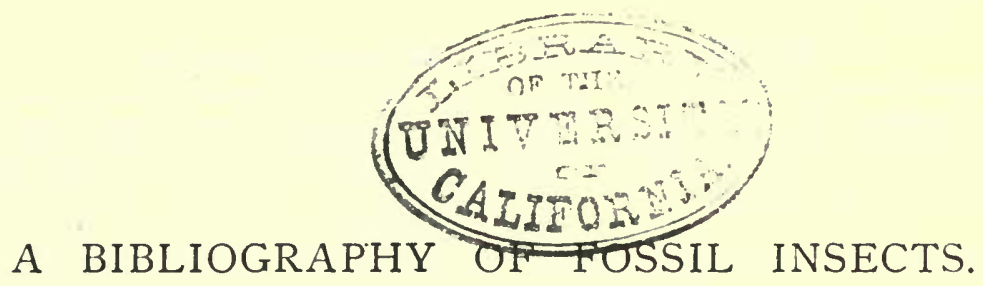

By Samuel H. Scudder.

Up to the present time, scarcely any formal attempt has been made to collect separately the titles of papers on fossil insects. Several authors, in general essays on this branch of palaeontology, have, indeed, referred to the older or the principal works upon the subject, as Giebel in his Insecten der vorwelt, Oustalet in his first essay on the fossil insects of France, and lately. and more particularly, Goss in his revieze of onr knoveledge of fossil insects. The principal sources of our inf formation. how: ever, have been portions of the scientific bibliographies of zoology; thus Carus and Engelmann, in $186 \mathrm{r}$, in their Bibliotheca zoologica (II. 2508-20), give two pages and a half to this subject with about sixty titles; while Hagen, $a$ year or two later. by means of the subject-index to his Bibliotheca entomologica refers to about one hundred and fifty articles, scattered throughout his work.

The following list was originally made for private use, to accompany a slip catalogue of the described fossil insects of the world prepared for comparing the ancient insect fauna with the modern. and that of the Old World with that of the Nez. Thinking it of nore thin private value, the entries have been accompanied by brief descriptive notes, and are here published as a tolerably complete list, and one that will at least suggest the extent and to some degree the nature of the literature upon this subject. Although more than double the extent of Hagen's list (which did not include A rachnidur and Myriapoda) this is no proof of an inereased dez'elopment of or interest in this branch of scientific work within the past fifteen years; indeed, it is doubtful whether there is now as much activity as in the previous fifteen years when the works of Heer were opening the wealth of material at hand. The multiflication of periodical literature of late years has brought in its train a host of minor papers many of them wholly popular in character, which, while they multiply titles, do not materially add to our actual knowledge. All of these the careful bibliographer must notice, and these have unfortunately enhanced the labor of preparing, and increased the extent of this list, without corresponding advantage.

All papers here quoted have been personally examined unless noted to the contrary: and, with rare exceptions, will bc found in the libraries of this vicinity. Although not properly belonging here, I have added references to articles treating of insects in copal. The arrangement under the authors is chronological

Additions to this bibliography would be very welcome, and will be inserted in an appendix.

Agassiz, L. See Buckland, W.

Allen, Grant. The colour sense; its origin and development. An essay in comparative psychology. 80. London. 1879. pp. 12, 282 .

In a chapter (4) on "insects and flowers," he discusses briefly the antiquity of insects and their relation to the earliest entomophilous Howers. See especially pp. 38, 42-46, 66-69, 78-8o.

American naturalist, Editors of. Fossil insects. Amer. nat. 2.: 163. fig. I, 2. 80. Salem. I868.

Note (not original) on Xenoneura and Palaeocampa.

Andrae, Karl Justus. Beiträge zur kenntnisse der fossilen flora Siebenbürgens und des Banates. Mit zwölf tafeln. pp. I-48. pl. I-12. Abhandl. k. k. geol. reichsanst. Wien. bd. 2. abth. 3. no. 4. $4^{\circ}$. Wien. I855.

Figures a Formica, pl. 4, fig. 6, 6a, 8b, and Chrysopa, pl. 5, fig. 3, 3a, from Thalheim, with mention of them on p. 26. - The Formica, like the Chrysopa, is said to come from Thalheim, but the locality of the plant on the same slab with the former is given as Sotzka I

Andrae, K. J. Eine alge und eine insectenflïgel aus der steinkohlenformation Belgiens. Sitzungsb. niederrhein. gesellsch. Bonn. 1876, 27-28. So. Bonn. I877.

Mere mention of a Blattina.

Andree, Richard. Die versteinerungen der steinkohlenformation von Stradonitz in Böhmen. Neues jahrb. f. mineral. geol. und pal. 1864. $2^{\text {es heft. }}$ s. 160-176. taf. iv. So. Stuttgart. 1864.

Describes and figures $A$ cridites priscus.

Anon. Gab es schon während der steinkohlen. zeit schmetterlinge? Kosmos, bd. 5, s. 218-19. 80. Leipzig. I879.

An account of the discussion of this subject in Nature and elsewhere, by Wallace, MacLachlan, de Borre, etc.

d'Archiac [Vicomte] et de Verneuil, Édouard. On the fossils of the older deposits in the rhenish provinces; preceded by a general survey of the fauna of the palaeozoic rocks, and followed by a tabular list of the organic remains of the devonian system in Europe. Trans. geol. soc. Lond. (2). vol. 6, pp. 303-410. 4\%. London. I842.

Contains, p. 330, a section (ix.) of a single paragraph on what was then known of palaeozoic insects.

[d'Argenville, Ant. Jos. Desallier.] L'histoire naturelle eclaircie dans une de ses parties principales, l'oryetologie, qui traite des terres, des pierres, des métaux, des minéraux et autres fossiles, ouvrage dans lequel on trouve une nouvelle méthode latine et francoise de les diviser, et une notice critique des principaux ouvrages qui ont paru sur ces matières. Enrichi de figures dessinées d'après nature. Par $\mathbf{M}_{\text {.*** }}$ * des Sociétés royales des sciences de Londres et de Montpellier. $4^{\circ}$. Paris. 1755 . pp. (8) 16, 562. pl. 26.

Mentions some fossil insects on pp. 83, 353; and on p. 360, pl. 21, refers to what is called a "chenille" and "deux papillons."

Assmann, August. Palaeontologie. Beiträge zur insekten-fauna der vorwelt. - Einleitung. I. Beitrag. Die fossilen insekten des tertiären (miocenen) thonlagers von Schosznitz bei Kanth in Schlesien. II. Beitrag. Fossile insekten aus der tertiären (oligocenen) braunkohle von Naumburg am Bober. Mit einer tafel abbildungen. So. Breslau. 1869. pp. I-62. Taf. I. Zeitschr. f. entom. des vereins f. schles. insektenk. (2) 1 .

The introduction, of thirty pages, gives a general review of fossil insects. The first paper contains an account of the geology and palaeontology of Schoszinitz with full descriptions of ten species of insects. The second describes two Coleoptera. I have only seen the separate edition.

Audouin, Victor. Sur une empreinte d'aile d'un insecte névroptère inconnu... trouvé en Angleterre à Colebroskedale dans le Shropshire ... dans un terrein houiller. Ann. soc. ent. France. vol. 2., bull. ent. pp. 7-8. 80. Paris. I833.

The first mention of a palaeozoic insect. It is said to have been shown by Audouin at the meeting of the Association of German naturalists at Bonn in 2835 , but I have been unable to examine the report of that meeting. Also mentioned by Boue in his Resume des progrits de la geologie, 1833, p. 346 , and in the Fourn. d. gkol. iii. zos (neither seen). 
Aymard, Auguste. La découverte d'un assez grand nombre d'insectes dans les marnes suborJonnées à la formation gypseuse près du Puy. Bull. soc. géol. France. vol. 6. pp. 235-36. So. Paris. IS35.

A brief announcement with a consideration of its geological import.

Ballenstedt [Johannes Georg Justus]. Entdeckung von insekten-nestern der urwelt im bernstein. Archiv f. d. nenest. entd. a. d. urw., bd. 5. s. 28-40. 8. Quedlinburg und Leipzig. I823.

A very full abstract of Troost's paper, with comments.

Bar [Constant]. Sur la Breyeria borinensis. Comptes rendus soc. ent. Belg. (2) xxviii : 6. So. Bruxelles. I $\$ 76$.

Ann. soc. ent. Belg. I9, comptes rendus, 53-54. 80. Bruxelles. $\mathrm{i} \$ 76$.

Considers Breyeria an honıpterous insect, and maintains that the lack of flowers in carboniferous times is not proof of the absence of Lepidoptera.

Barthélemy-Lapommeraye, A. Carabe d'Agassiz, Carabus Agassizi. 8o. pp. 4. Marseille. [1850.]. Extract and notice by G(uerin) $\mathrm{M}$ (eneville) under same title. Rev. et mag. zool. (2). zol. 3, pp. 203-04. 80. Paris. 1851 .

Bassi, Carlo Agostino. Memorie intorno allo studio degl' insetti fossile in genere. Atti reun. scienz. ital. 3: 400-01. 4\%. Firenze. I841.

An account of three or four insects from Sinigaglia in the Milan museum, to only one of which a name-Cleonolithus antiquus - is given. None of them are properly described.

An abstract entitled Ueber die wichtigkeit des studiums der fossilen knochen [kerfen?] für die geologie will be found in Oken's Isis, 1843, pp. 418-19. $4^{\circ}$. Leipzig. 1843 .

Beck [H.?]. Notes on the geology of Denmark. Proc.geol. soc. Lond. 2 : 217-20. 80. London. 1836. I 836 .

Lond. Edinb. phil. mag. (3) 8: 553-56. 80. London.

Contains a paragraph relating to tertiary deposits of Jutland "older than the erratic blocks" and containing "the elytra of beetles, the cases of the larvae of Phryganaea, and a hymenopterous insect which the author bas called Cleptis Steenstrupii."

Beckles, S. H. On the lowest strata of the cliffs at Hastings. Quart. journ. geol. soc. Lond. vol. 12, proc. pp. 288-92 ; with a section. 80. London. 1856 .

Merely mentions (p. 29r) the discovery of insects in the upper members of the series, referred to the wealden.

van Beneden, P. J., et Coemans, Eug. Un insecte et un gastéropode pulmoné du terrain houiller. 8o. pp. 20 . pl. Bull. acad. roy. Belg. (2) 23 , iv. 384-401, pl. 8o. Bruxelles. I867.

Describes in detail and figure $O$ malia macroptera, which the authors consider allied to Hemerobius.

Berendt, Georg Carl. Die insekten im bernstein. Ein beitrag zur thiergeschichte der vorwelt. Ies heft. $4^{\circ}$. Danzig. I830. pp. (2) 39.

Only pp. 29-39 deal with the insects themselves, and the remarks are of a very general nature, but give the first published information concerning amber insects based on considerable collections. Hagen (Bibl. ent. i, 42) records plates to a second part.

Berendt, G. C. Mémoire pour servir à l'histoire des blattes antédiluviennes traduit de l'allemand par M. Heller. Ann. soc. ent. France, 5: 539-46. fl. 16. 8o. Paris. I 836.

Descriptions and figures of the species found in amber.

Berendt, G. C. Die im bernstein befindlichen organischen reste der vorwelt, gesammelt in verbindung mit mehreren bearbeitet und herausgegeben von Dr. Georg Carl Berendt. 2 v. fo. Berlin. I845-56. The covers entitled Organische reste im bernstein.

Contains four parts ; the first volume has the plants by Goeppert and Berendt (with general chapters on amber by Berendt), and the Crustacea, Myriapoda, Arachnida and Aptera by Koch and Berendt; the second volume, the Hemiptera and Orthoptera by Germar and Berendt, and the Neuroptera by Pictet and Hagen.

Berendt, G. C. See also Germar, E. F., und Berendt, G. C. ; Goeppert, H. R., und Berendt, G. C.; Koch, C. L., und Berendt, G. C. ; and Pictet-Baraban, F. J., und Hagen, H. A.

Beringer, J. D. A. Lithographiae virceburgensis, ducentis lapidum figuratorum, a potiori insectiformium, prodigiosis imaginibus exornatae specimen primum, quod in dissertatione inaugurali physicohistorica, cum connexis corollariis medicis, authoritate et consensu inclytae facultatis medicae, in alma eoo-francica wirceburgensium universitate, preside ... D. Joanne Bartholomaeo Adamo Beringer... exantlatis de more rigidis examinibus pro suprema doctoratus medici laurea, annexisque privilegiis ritè consequendis, publicae literatorum disquisitioni submittit Georgius Ludovicus Hueber. .... In consueto auditorio medico. Anno 1726. fo. Wirceburgi. pp. (12) 96, tab. 21.

Nearly half of the plates contain grossly exaggerated, worthless figures of insects, the text for which is crowded on p. 94 by mere descriptive titles to the plates. The specimens from which the plates were drawn are said to have been fabrications.

Bertkau, $\mathrm{Ph}$. Einige spinnen und ein myriapode aus der braunkohle von Rott. Verhandl. naturh. verein preuss. Rheinl. u. Westf. (4), 5: 346-360. taf. 5. 8o. Bonn. I 878 .

A careful description of eight species, of which six are new.

Bertrand, Elie. Dictionnaire universel des fossiles propres, et des fossiles accidentels, contenant une description des terres, des sables, des sels, des soufres, des bitumens, des pierres simples \& composées, communes \& prétieuses, transparentes \& opaques, amorphes \& figurées, des minéraux, des métaux, des petrifactions du règne animal, \& du règne végétal, \&c. avec des recherches sur la formation de ces fossiles, sur leur origine, leur usages \&c. 2 v. 8o. La Haye. ${ }_{1763}$.

Under the heading Entomolitbes, vol. I, pp., 201-02, is a very brief account of those then known, with bibliographical references.

Binfield, William R. and Henry. On the occurrence of fossil insects in the wealden strata of the Sussex coast. Quart. journ. geol. soc. Lond., vol. Io, proc. pp. 171-76. So. London. 1854.

The insects are mentioned only by suborders, and the paper is mostly made np of geological sections of the places where insects were found.

Binney, E. W. On two remarkable fossil insects from the lower coal measures near Huddersfield. Proc. lit. phil. soc. Manch., 6: 59. 80. Manchester. 1867.

Geol. mag., 4: 132. 8o. London. 1867.

Notices the occurrence of Xylobius sigillariae and of a supposed coleopterous larva.

Blake, J. F. See Tate, R., and Blake, J. F.

Blanford, W. T. See Medlicott, H. B., and Blanford, W. T.

Bloch, D. Beytrag zur naturgeschichte des kopals. Berlin. 160. 1776. Beschäft. berl. gesellsch. naturf. fr. 2 : 91-196, tab. iii-v.

Contains, pp. 164-190, Verzeichniss einiger merkwürdigen insekten, welche in kopal eingeschlossen, with rude figures.

Bock, F. S. Versuch einer kurzen naturgeschichte des preussischen bernsteins und einer neuen wahrscheinlichen erklärung seines ursprunges. 160 . Königsberg. I767. pp. I46.

Gives on pp. $13^{8-146}$ a list of some insects and other animals found in amber. 
Boisduval, Jean Alphonse. Compte verbal du rapport ... sur un dessin ... qui représente une empreinte de lépidoptère fossile, trouvée dans les environs d'Aix. Ann. soc. ent. France. vol. 8, bull. ent. pp. 11-12. 80. Paris. 1839.

Compares the buttertly to the modern genus Cyllo. Reproduced in Scudder's Fossil butierfies, p. I5.

Boisduval, J. A. Rapport sur une empreinte de lépidoptère trouvée dans les marnes des environs d'Aix en Provence, et communiquée par M. de Saporta. Ann. soc. ent. France. zol. 9. pp. 371-74. pl. 8. 80. Paris. IS40.

Description of Cyllo sepulta. Reproduced in Scudder's Fossil butterfics, pp. $15^{-17}$.

Boisduval, J. A. Quelques mots de réponse à M. Alex. Lefebvre sur les observations relatives à la Cyllo sepulta, et à laquelle il donne pour épigraphe ces mots: Stupete gentes! Ann. soc. ent. France (2). vol. 9, bull. ent. pp. 96-93. So. Paris. IS 51 .

Rejoinder maintaining his own position and ridiculing that of Lefebvre. Reproduced in Scudder's Fossil butterfices, p. 26.

Bolton, John. On a deposit with insects, leaves, etc, near Ulverston. Quart. journ. geol. soc. Lond. vol. 18. proc. 274-77. figs. 1-2 (sections). 80. London. 1862 .

Mentions only a few insects determined in a general way by Mr. Henry Tibbats Stainton.

de Bonnac. Sur l'ambre jaune. Hist. acad. roy. sc. 1705: 41-44. $4^{\circ}$. Paris. 1730.

Concludes amber to be formed on the land from its enclosure of terrestrial animals, "comme des mouches, des fourmis, etc."

de Born, Ignace. Catalogue méthodique et raisonné de la collection des fossiles de Melle Éléonore de Raab. 2 v. 80 . Vienne, I 790. tom. 1, pp. (48), 502. tom. 2, pp. (8) 499 (66), tab. 1.

Contains: Pétrifications d'insectes-entomolithes I., pp. ${ }^{464-}$ 466 ; mentions four insects.

de Borre, A. Preudhomme. Note sur des empreintes d'insectes fossiles, découvertes dans les schistes houillers des environs de Mons. Comptesrendus soc. ent. Belg., (2) xii : 4-7 (and discussion on same by Breyer and others, 7-8). 8o. Bruxelles. I 875 .

Describes and discusses the affinities of two fossil insects which he considers orthopterous; and of a third which he conspares to a carboniferous lermes. Breyer considers one of the first wings as lepidopterous.

de Borre, A. P. Complément de la note sur des empreintes d'insectes fossiles. Comptes-rendus soc. ent. Belg., (2) xiii. 7-1 I (and discussion on same by Fologne, Lafontaine, Plateau, Breyer, and de Sélys, I I-12). So. Bruxelles. I875.

Now maintains the correctness of Breyer's belief that one of the wings is lepidopterous, or prolepidopterous, and changes the generic name from Pachytylopsis, formerly given, to Breyeria. Fologne and Lafontaine contend that there are two overlapping wings. Plateau at first thought it the tip of a coleopterous wing of gigantic size, but withdrew his opinion. Breyer maintained the latter view impossible, and de Sélys thought it rash 10 refer a reticulated wing to the Lepidoptera. These two papers, withreticulated wiscussion, were republished separately as follows: -

de Borre, A. P. Notes sur des empreintes d'insectes fossiles découvertes dans les schistes houillers des environs de Mons. 8o. Bruxelles. 1875. pp. 1-10, pl. v-vi. Ann. soc. ent. Belg. 18, pp. 39$42,56-60$, pl. v-vi. So. Bruxelles. 1875.

Premier note, pp. I-6 (39-42). Seconde note, pp. 6 -10 $(56-60)$. Second note reprinted as follows :-

Empreintes d'insectes fossiles découvertes dans les schistes des environs de Mons. Fourn. zool., vol. 4, p.t. 29I -97 . 8o. Paris. I875.

Unacenmpanied by the plate. Gervais adds brief notes. de Borre, A. P. Sur trois nouveaux insectes fossiles. Comptes-rendus soc. ent. Belg. (2) xviii., 17. So. Bruxelles. 1875 .

Ann. soc. ent. Belg. 18, comptes-rendus if 5.80, Bruxelles. I 875 .

Notice of the discovery of two Neuroptera from the same beds as Breveria and of a supposed dipteron from the jurassic beds of Luxembourg; 11 . de Borre informs me that closer examination proves the latter to be an homopteron.

de Borre, A. P. |Acknowledgment of objections to the lepidopterous character of Breyeria from Hagen, Heer, Giard, and Scudder.] Compies-rendus soc. ent. Belg. [2] xxii. 5-6 (followed by discussion of the subject by Saporta and Weyers, pp. 6-7). So. Bruxelles. $1 \$ 76$.

Ann. soc. ent. Belg. 19:3-4. 8o. Bruxelles. 1876 .

de Borre, A. P. Note sur le Breyeria borinenis. pp. 6. So. Bruxelles. 1879. Comptes-rendus soc. ent. Belg. (2) lxv : 7-12. 80. Bruxelles. 1879.

Maintains Breyeria to be an ancestral stock of the type of Lepidoptera.

de Borre, A. P. See also Giard, A. ; and van Volxem, C.

Bosc, Louis [Augustin Guillaume]. Note sur une fossile remarquable de la montagne de Saint-Géraudle-Puy, entre Moulins et Roanne, département de l'Allier, appelé l'indusie tubuleuse. Fourn. d. mines, vol. $17, p p .397-400, p l .7$. 8o. an xiii.

The first notice of the remarkable caddis-fly cases of Auvergne, forming the beds of so-called indusial limestone.

Bouve, T. T. See Deane, J.

Brauer, Friedrich. Verzeichniss der bis jetzt bekannten neuropteren im sinne Linné's. pp. 90 [n. d.] Verhandl. k. k. zool.-bot. gesellsch. Wien. bd. is: 359416, 7 II-42. 8o. Wien. 1868.

Includes the fossil genera and species, and contains, p. 738 (86), a list of the fossil Libellulina.

Brauer, F. Betrachtungen über die verwandlung der insekten im sinne der descendenztheorie. So. Wien. 1869. pp. 21, pl. Verhandl. k. k. zool.-bot. gesellsch. Wien. 19: 299-319, pl. 10. 8o. Wien. i869.

Contains, p. 19 [317], a slight reference to the structure of Eugereon.

[Braun, F.] Verzeichniss der in der kreis naturalien sammlung zu Bayreuth befindlichen pt trefacten. $4^{\circ}$. Leipzig. I840. pp. viii, I I8, karte, tabelle, taf. 22 .

Div. 6, Insecta, p. 71 , mentions three insects from the braunkohl.

Breyer. See de Borre, A. P.

Breyn, Johann Philipp. Observatio de succinea gleba, plantae cujusdam folio impraegnata, rarissima. Phil. trans. 34, 1 54-56 pl., fig. 2. $4^{\circ}$. London. 1728. Mentions a spider and a fly in amber. with minute figure of latter.

Brodie, Peter Bellinger. A notice on the discovery of the remains of insects, and a new genus of isopodous Crustacea belonging to the family Cymothoidae in the wealden formation in the Vale of Wardour, WVilts. Proc. geol. soc. Lond., 3 : 134-35. 80. London. 1839.

Lond. Edinb. phil. mag. (3) I 5 : 534-36. 8o. London. 1839 .

A section of the locality with a general account of its fossil remains. those of the Insects belonging to several orders. An extended notice will be found in the Neues jahrb. f. mineral. $1843: 238-39 . \quad 8^{\circ}$. Stuttgart. 1843.

Brodie, P. B. On the discovery of insects in the lower beds of lias of Gloucestershire. Rep. brit. assoc. adv. sc. 1842 : notices, 58. So. London. 1843 .

General notice of the finding of a few insect remains, mostly coleopierous, near Cheltenham. 
Brodie, P. B. Notice on the discovery of insects in the wealden of the Vale of Aylesbury, Bucks, with some observations on the clistribution of these and other fossils in the Vale of Wardour, Wiltshire. A m. mag. nat. hist. I I : 4So-S2. 80. London. I 843 . Sufficiently described by the title.

Brodie, P. B. Notice on the discovery of insects in the wealden in the Vale of Aylesbury, Bucks, with some additional observations on the wider distribution of these and other fossils in the Vale of IV ardour, IViltshire. Lond. Edinh. Dubl. phil. mag. (3) $23: 512-14$. 8o. London. IS 43 . 1843 .

Proc. scol. soc. Lond. $4: 780-\$ 2$. So. London. Same as the preceding.

Brodie, P. B. Notice on the discovery of the remains of insects in the lias of Gloucestershire, with some remarks on the lower members of this formation. Lond. Edinb. Dubl. phil. mag. (3) 23 : 529-3 I. So. London. I843.

Ann. mag. nat. hist. II : 509-I I. So. London. I843.

Proc. geol. soc. Lond. 4 : I4-16. 80. London. $1842-43$.

Athenaeum, I843:40-41. $4^{\circ}$. London. I 843 .

Notice of the discovery and geological position of insects near Gloucester and Cheltenham, at Wainlode Cliff and Westbury; an extension of the paper mentioned from the British association report.

ABSTRACT: Sur des débris d'insectes du lias du Gloucestershire. L'institut I843, i. $47.4^{\circ}$. Paris. 1843 .

ABSTRACr: Notiz über die entdeckung von insectenresten im lias von Gloucestershire mit einigen bemerkungen über die untern glieder dieser formation. Neues jahrb. f. mineral. 1844: 127-28. 80. Stuttgart. I 844 .

Brodie, P. B. A history of the fossil insects in the secondary rocks of England. Accompanied by a particular account of the strata in which they occur, and of the circumstances connected with their preservation. 80. London. I845. pp. (I8) I30, pl. II.

The introductory observations, explanation of plates, notes, and many names, are by Westwood. This, the only separate work on fossil insects published in England, is still the chief source of our too inexact knowledge of the liassic and other secondary insects of that country. The body of the work, $\mathrm{Mr}$. Brodie's part, is divided into four chapters. of which the first deals with the wealden, the second with the oolite, the third wish the lias, and the fourth with miscellaneous matter, including insects of continental strata.

Brodie, P. B. On the insect-limestone and its associate beds. Murchison, Outl. geol. Cheltenham. $2 \mathrm{~d}$ ed. 5I-53. So. London. I845.

Simply a discussion of the mode of deposition of these rocks.

Brodie, P. B. Notice of the existence of purbeck strata with remains of insects and other fossils, at Swindon, Wilts. Quart. journ. geol. soc. Lond., 3, proc. 53-54. So. London. I 847 .

A geolngical paper, giving no further account of the insects than appears in the title.

Brodie, P. B. Notice on the discovery of a dragon fly and a new species of Leptolepis in the upper lias near Cheltenham, with a few remarks on that formation in Gloucestershire. 8o. pp. 4, pl. Quart. journ. geal. soc. Lond., 5, proc. $3^{1-37}$. pl. 2. 80. London. I 848 .

The description (2 pp.) is by Westwood, but the name, Libellula (Heterophlebia) dislocata, is by Brodie. The rest of the paper is on the geology of the district. I have not seen the separate paper.

Brodie, P. B. Notice of the occurrence of an elytron of a coleopterous insect in the Kimmeridge clay at Ringstead Bay, Dorsetshire. Quart. journ geol. soc. Lond., 9, proc. 51-52. 80. London. I8 53 . No further details of the insect than are given in the title.

Brodie, P. B. On the occurrence of the remains of insects in the tertiary clays of Dorsetshire. Quart. journ. geol. soc. Lond. 9, proc. 53-54. 80. London. I 853 .

Refers to a few Curculionidae and Buprestidae found at Corfe, afterwards figured by Westwood.

Brodie, P. B. On the insect beds in the purbeck formation of Dorset and Wilts; and a notice of the occurrence of a ncuropterous insect in the Stonesfield slate of Gloucestershire. Quart. journ. geol. soc. Lond., 9, proc. 344. 80. London. I\$ 53.

Published only by title; probably same as next.

Brodie, P. B. On the insect beds of the purbeck formation in Wiltshire and Dorsetshire. Quart.journ. geol. soc. Lond., Io, proc. 475-S2. So. London. IS54.

Moslly occupied with geological sections, but p. $48 \mathrm{r}$ gives an account, in general terms, of the condition and cliaracter of the insects discovered, most of which were Coleoptera.

Brodie, P. B. Fossil insects in the carboniferous rocks. Geol. mag. 4: 285-86. So. London. IS67.

A brief enumeration of the different forms known to the author.

Brodie, P. B. A sketch of the lias generally in England, and of the insect and saurian beds. Proc. Warw. nat. arch. field club, I868. pp. I-24. 80. Warwick. 1868.

Mostly occupied with the geology of the insect-beds, but with occasional reference (especially on pp. I $8-19$ ) to the insects contained in them.

Brodie, P. B. Exploration of the leaf-beds in the lower Bagshot series of Hants and Dorset. Geol. mag., vol. $7, p$. 141. So. London. I870.

Suggestions for further search.

Brodie, P. B. The distribution and correlation of fossil insects, and the supposed occurrence of Lepidoptera and Arachnidae in british and foreign strata, chiefly in the secondary rocks, ... being a paper read at the annual meeting of the Warwickshire natural history and archaeological society, held at the museum, Warwick, April i 8 th, IS73. So. Warwick. [n. d.] pp. I9. Ann. rep. Warw. nat. hist. arch. soc. 37 : 12-28. 80. Warwick. I873.

A very general account of fossil insects, followed (pp. 12-19) by a Tabular view of british and foreign fossil insects chiefly in the secondary rocks, omitting the foreign tertiaries. Separate paper only seen.

Brodie, P. B. The distribution and correlation of fossil insects, and the supposed occurrence of Lepidoptera and Arachnidae in british and foreign strata, chiefly in the secondary rocks, ... being a paper read at the annual meeting of the Warwickshire naturalists' and archaeologists' field club, held at the museum, Warwick, February 24, i 874 . So. Warwick. [n. d.] pp. 23. Ann. rep. Warw. nat. arch. field club. 1874. $p p .16-38$.

An enlargement of the last, principally in the Tabular view. Like the preceding it is much disfigured by ty pographical errors.

Brodie, P. B. Notes on a railway-section of the lower lias and rhaetics between Stratford-on-Avon and Fenny Compton, on the occurrence of the rhaetics near Kineton, and the insect beds near Knowle, in Warwickshire, and on the recent discovery of the rhaetics near Leicester. Quart. journ. geol. soc. Lond. vol. 3o, i. $p p .746-49$. 80. London. IS\%4.

Simply notices the discovery of certain insects at Copt Heath near Knowle.

Brodie, P. B. The lower lias at Eatington and Kineton, and on the rhoetics in that neighbourhood, and their further extension in Leicestershire, Nottinghamshire, Lincolnshire, Yorkshire, and Cumber- 
land; . . being a paper read at the annual meeting of the Warwickshire natural history and archaeological society, held at the museum, Warwick, April 2nd, 1875. So. Warwick. [n. d.] pp. I4. Ann. rep. Warw. nat. hist. arch. soc.

Principally occupied with geology, but with a few special references to insects, particularly on p. 10; separate only seen.

Brodie, P. B. Fossil Lepidoptera. Ann. rep. proc. Warw. nat. arch. field club, 1877. pp.3-9. 80. Warwick. I 877 .

Not seen. The author states that it is based on Scudder's work on the subject and contains nothing original.

Brodie, P. B. The nature, origin, and geological history of amber, with an account of the fossils which it contains. So. [Warwick.] n. d. pp. 15. Ann. rep. proc. Warw. nat. arch. field club, I 878 ?

Notices of the insect enclosures are mostly confined to pp. 8-12, and are of a general nasure ; separate only seen.

Brodie, P. B. On the discovery of a large and varied series of fossil insects and other associated fossils in the eocene (tertiary) strata of the Isle of Wight. So. IVarwick. I 878. pp. 12. Ann. rep. proc. Wariv. nat. arch. field club, 1878 . So. Warwick. I 878 .

A general popular account; only the separate paper seen.

Brodie, P. B. See also Strickland, H. E.

Bromell, Magnus. Lithographiae svecanae continuatio. Specimen II. - Sectio II. De animalibus fossilibus, illorumque variis partibus petrificatis. - Caput primum. De lapidibus insectiferis \& tubulis vermicularibus. - Articulus primus. De lapidibus insectiferis scanicis \& gothicis. Acta liter. Sveciae, vol. 2, pp. 493-97, 524-33 . figs. $4^{\circ}$. Upsaliae et Stockholmiae. $\quad$ i729.

A general notice of the discovery of insects, "Scarabaei" and "Papiliones", in rocks of Karabylonga, Giärstad, Knista, Olstorp, and Aklinge.in Westrogothia.

Brongniart, Alexandre. Sur les terrains qui paroissent avoir été formés sous l'eau douce. Ann. mus. hist. nat., I 5: 357-405, pl. 23-24. 40. Paris. 18 ro.

Discusses Indusia tubulata on pp. 392-93.

Brongniart, A. Succin. Dict. sc. nat., 51 :22940. 80. Strasbourg et Paris. 1827.

Mentions in general terms (p. 233-34) the insects most commonly found in amber.

Brongniart, Charles. Observations sur un insecte fossile de la famille des diptères trouvé à Chadrat (Auvergne), (Protomyia Oustaleti). Ann. sc. geol., 7, art. no. $4, p p$. 2. 80. Paris. 1876.

Brongniart, C. Note sur une nouvelle espèce de diptère fossile du genre Protomyia ( $P$. Oustuleti), trouvée à Chadrat (Auvergne). Bull. soc. géol. France, (3), vol. 4, pp. 459-60, pl. I 3 , figs. 5-8. 80. Paris. 1876.

Same as the preceding.

Brongniart, C. Rapport sur un morceau de bois fossile trouvé dans le gault, terrain crétacé de Lottinghem (Pas-de-Calais). Ann. soc. ent. France, (5), vol. 6, bull. ent., 117-18. So. I'aris. 1876.

Refers the borer reported by Lartigue (q. v.) to Bostrychus.

Brongniart, C. Note sur des perforations observées dans deux morceaux de bois fossile. $A n n$. soc. ent. France, (5), $7: 215-20$, pl. 7, ii. 8o. Paris. 1877 .

Describes the borings of a xylophagid allied to Hylesinus. Noriced by Dr. Hector George in the Feuilleton of Le constitutionnel for $2 i$ Nov., 1877 . See also Girard, M.

Brongniart, C. Note sur une Aranéide fossile des terrains tertiaires d'Aix (Provence). Ann. soc. ent. France, (5), 7 : 22I-24, pl. 7, i. So. Paris. I 877 .

Describes Attoides eresiformis. Noticed by Dr. Hector George in the Feuilleton of Le constitutionnel for 21 Nov., 1877 . See also Girard, M.

Brongniart, C. Note rectificative sur les espèces de bibionides fossiles du genre Plecia. Bull. séances soc. ent. France, I878, vi : 60-61. 80. Paris. 1878 .

Ann. soc. ent. France, (5), vol. 8, bull., fp. 47-48. 8o. Paris. 1878 .

The fossil Diptera described as Protomyia and Bibicpsis belong to the modern genus Plecia.

Brongniart, C. Note rectificative sur quelques diptères tertiaires et en particulier sur un diptère des marnes tertiaires (miocène inféricur) de Chadrat (Auvergne) la Protomyia Oustaleti qui devra s'appeler Plecia Oustaleti. So. Lille. 1878. t. p. pp. 73-81. Bull. scient. dép. nord, (2), ann. I, pp. 73-SI. So. Lille. I878.

Discusses in full the species of fossil Bibionidae described as Protomyiae and Bibiopsides, and concludes that all belong to Plecia ; redescribes Plecia Uustaleti; an enlargement of the preceding paper.

Brongniart, C. Note sur la découverte d'un orthoptère coureur de la famille des phasmiens (Pro tophasma Dumasi) dans les terrains supra-houillers de Commentry (Allier). Bull. séances soc. ent. France, 1878, vii : 69-70. So. Paris. 1878 .

Same with omission of the word "Note" in the title. Ann. soc. ent. France, (5), vol. 8, bull., pp. 57-58. 80. Paris. 1878 .

Same as the last. 80. Bruxelles. I878. pp. 4. Comptes rendus soc.ent. Belg., (2), 47 : 9-1 2. 80. Bruxelles. 1878 .

Brongniart, C. Note sur un nouveau genre d'orthoptère fossile de la famille des phasmiens provenant des terrains supra-houillers de Commentry (Allier) (Protophasma Dumasii). So. Paris. 1878. pp. 9, pl. Ann. sc. nat., (6), zool., tom. 7, art. 4, pp. 8, pl. 6. So. Paris. I 878 .

Text substantially the same as the preceding. Noticed by Dr. Hector George in the Fevilleton of Le constitutionnel, Nov. 6,1878 ; and also read before the Association scientifique de France in 1878 . See also Girard, M. A discovery carrying th is group of Orthoptera back at once from the tertiary to the permian.

Brongniart, Charles. On a new genus of orthopterous insects of the family Phasmidae (Protoplasma Dumasii) from the upper coal measures of Commentry, dept. Allier, France. 80. London. 1879. pp. $6 \mathrm{pl}$. - The cover entitled New fossil insect from the coal measures. Geol. mag., n. s., Dec. 2, vol. 6, $p p$ 97-102, pl. 4. 8o. London. 1879.

Translation of the preceding.

Bronn, Heinrich Georg. Lethaea geognostica, oder Abbildungen und beschreibungen der für die gebirgs - formationen bezeichnendsten versteinerungen mit lithographirten 47 quart-, I folio-tafel und 2 tabellen. 2 v. 80. Stuttgart. I835-38. i. pp. 6, 768; ii. pp. [4] 769-I 346 [4].

Contains references to fossil insects on pp. $210,481,794,800-$ 14, 1159-61. A second edition, which $I$ have not seen, was published in 1838 . The third was by Bronn, H. G., and Roemer, F., $q . v$.

Bronn, H. G. Index palaeontologicus oder Uebersicht der bis jetzt bekannten fossilen organismen, unter mitwirkung der ... H. P. Göppert und Herm. v. Mayer, bearbeitet von Dr. H. G. Bronn. Erste abtheilung. A. Nomenclator palaeontologicus, in alphabetischer ordnung. pp. $6,84,1382$. 80. Stuttgart. I 848 . Zweite abtheilung. B. Enumerator palaeontologicus ; systentatische zusammenstellung und geologische entwickelungs-gesetze der organischen reiche. t. p. pp. 980.80 . Stuttgart. 1849. 
13. (pp. $\left.5^{8} 5-632\right)$ refers to the geological distribution of insects. This also appeared as Bd. 3 of the author's Handbuch der geschicte der natur. $S^{*}$. Stuttgart. $\quad S_{+1} 49$.

Bronn, H. G. Essai d'une réponse à la question de prix proposée en $185^{\circ}$ pour le concours de I 853 , et puis remise pour celui de 1856 , savoir : Etudier les lois de la distribution des corps organisés fossiles dans les différents terrains sédimentaires, suivant l'ordre de leur superposition. Discuter la question de leur apparition ou de leur disparition successive ou simultanée. Rechercher la nature des rapports qui existent entre l'état actuel du règne organique et ses états antérieurs. Suppl. comptes rend. acad. sc., t. 2, $p p \cdot 377-918 . \quad 4^{\circ}$. Paris. 1858.

Bronn, H. G. Untersuchungen über die entwickelungs-gesetze der organisclien welt während der bildungszeit unserer erd-oberfläche. Eine von der französischen akademie im jahre I 857 gekrönte preisschrift, mit ihrer erlaubniss deutsch herausgegeben. So. Situtgart. IS 58 . pp. I0, 502.

Translation of the preceding. The insects will be found treated in the original edition of this justly celebrated essay on pp. $43^{8}-53,636-3^{8}, 810-12,865^{-6}$.

Bronn, Heinrich Georg und Roemer, Ferdinand. H. G. Bronn's Lethaea geognostica oder Abbildung und beschreibung der für die gebirgsformationen bezeichnendsten versteinerungen. Dritte stark vermehrte auflage. Mit einem atlas von I24 tafeln. 3 v. 80. Stuttgart. $I_{5} S-56$. Atlas fol.

Bd. I. pp. 12, 204, 6. $788-1851-56$; bd. 2. pp. 8, 124, 4, 570, 4, 412-1851-52; bd. 3, pp. 8, 1130-1853-56. Atlas, tille, schema, pl. $1-63-1850-56$. Insects are discussed or tabulated, and typical species described, none of them new, in I. $i, 4^{2-54}$ ii. I3, 75, 679-8 ; II. iv, 32, 429-30; III. vi, 52, 86, 622-50, and figured pl. $9^{3}, 4 \mathrm{r}^{\mathrm{Ia}}, 42^{1^{3}}$.

Brown, John. Insects and seeds in peat at Stanway. Gcologist, 1858: 254. 80. London. $185^{8}$.

Notes the occurrence of elytra.

Brullé, Aug. Sur le gisement des insectes fossiles, et sur les secours que l'étude de ces animaux peut fournir à la géologie. Thèse pour le doctorat es-sciences. $4^{\circ}$. Paris. 1839. pp. [4] 30.

A studied review of the knowledge at that time, from which the conclusion is drawn that nearly all fossil iosects are generically, and part of them specifically, identical with living types, and that in these particulars they agree with other fossil animais.

Brydone, Patrick. $\Lambda$ tour through Sicily and Malta, in a series of letters to William Beckford, Esq., of Somerly in Suffolk. A new edition. 2 vols. 8o. London. 1776. i. map, pp. 16, 373; ii. pp. I I, 355.

Vol. 1, pp. 282-84 contains a short account of the amber found at the mouth of the Giaretta containing "flies and other insects." The first edition was published in 1774 ; another in $1775 ; \mathrm{zn}$ other with preciseiy the same pagination as in the one quoted, in 1790 ; anolher in 1806 ; a French translation in 1775 at Paris, and in 1819 at Francfort; and a German translation in 1727 a Leipzig.

von Buch, Leopold. See Erichson, IV. F.

Buckland, William. Geology and mineralogy considered with reference to natural theology. [Bridgewater treatise.] 2 vols. So. London, 1837. Vol. I, pp. I6, 6I9; vol. 2, pp. 7, III, pl. I-69 (=88 pl.).

Buckland, W. The same. 2 vols. 8o. Philadelphia. I837. Vol. I, pp. 443 ; vol. 2, pp. I3I, pl. as in above.

Buckland, W. Geologie und mineralogie in beziehung zur natkirlichen theologie.... Aus dem etrglischen, nach der zweiten ausgabe des originals, uebersetzt und mit anmerkungen und zusaetzen versehen von Dr. Louis Agassiz. 2 vols. So. Bern, Chur und Leipzig. I 838 .

Vol. i. [text] ; t. p., pp. 26, 508 ; vol. ii. [plates]; t. p., pp. 4, pl.
$4^{6}$ and $46^{\prime \prime}$ are devoted to fossil insects, mostly arachnids, copjed from Corda. The orhers are insects Irom Coalbrook-Dale, Stonefield, and Aix. The brief text concerning them is found in the I.ondon edition at i. 406-13, and ii. 74-79; in the American edition at i. 306-11 and ii. $74-79$; in the German at pp. 453-6́3. The additions by Agassiz consist of a couple of unimportant notes. A new edition by Frank Buckland (London, portant notes. A new edition by Frank Buckland (Londoll,
1858) I have not seen, and the Loudon edition examined is the second, apparently agreeing in every respect with the first, published in 1536 .

Buckland, W. On the discovery of a fossil wing of a neuropterous insect in the Stonesfield slate. Proc. greol. soc. Lond., 2 : 6S8. 80. London. 1838.

Lond. Edinb. Dubl. phil. mag., [3], 13: 388. so. London. 1833 .

Brief notice of Hemerobioides giganteus.

Buckland. IV. Découverte d'une aile fossile d'insecte névroptère dans les schistes de Stonesfield. K'er. zool., 1839, 29. 80. Paris. I839.

Abstract of the above, by Malepeyre.

Buckland, IV. Notices relative to palaeontology ... from his anniversary address to the geological society of London. Ann. mag. nat. hist., 9: $156-67$. 8o. London. I 842 .

Address in full. Proc. geol. soc. Lond., 3:469-540. 8o. London. 1841 .

Contains fossil arachnidans (with opinjons of Gray (J. E.) quoted), pp. 162-63 (pp. 504-05). Fossil insects, p. 163 (p. 505.) Notices the arachnids described by Corda as well as specimens from Solenhofen and Aix: and the discovery of various insects the previous year from the wealden, Stonesfield slate, and Staffordshire coal, together with Hymenoptera from coa near Glasgow.

Buckman, James. On the occurrence of the remains of insects in the upper lias of the county of Gloucester. Proc. geol. soc. Lond., vol. 4, pp. 211 1-12. 8o. London. 1843 .

Lond. Edinb. Dubl. phil. mag., vol. 24, p. 377. 80. London. I844.

Notices Aeschna Brodiei, without description, and the occurrence of two Coleoptera and a Tipula at Dumbleton.

Buckman, J. Remarks on Libellula Brodiei (Buckman), a fossil insect from the upper lias of Dumbleton, Gloucestershire. Ann. mag. nat. hist., [2], $12: 436-3^{8}$. So. London. 1853 .

Claims Aeschna Brodiei, Libellula (Heterophlebia) dislocata, and Agrion Buckmani to be one insect which should bear the name in title.

Buckman, J. See also Murchison, R. I.

Burmeister, Hermann. Kerfe der Urwelt. Burm., Handb. d. cnt., zol. I, pp.632-40. 80. Berlin. I832.

A brief resumé of what was known at that time, with some original statements concerning the insects observed by him in amber.

Burmeister, $H$. Insects of a former world. Burm.-Schuck., Man. ent., pp.574-8i. 8०. London. 1836 .

Translation of the above.

Burmeister, H. Geschichte der schöpfung. Eine darstellung des entwicklungsganges der erde und ihre bewohner. So. Leipzig. I843. pp. 6, 487.

Refers to insects on pp. 430,445-46. The five subsequent editions not examined.

\section{Burmeister, H. See also Hünefeld.}

Butler, Arthur Gardiner. Catalogue of the diur. nal lepidoptera of the family Satyridae in the collection of the British museum. 80. London. 1868. pp. 6, $2 \mathrm{I}$, pl. 5 .

Under the heading Fossil species, pp. I $80-00$, are given brief notes on Neorinopis sepulta, to show that it " is exactly intermediate in character between ... Neorina, Antirrhoea, and Anchiphlebia."

Butler, A. G. Catalogue of diurnal lepidoptera described by Fabricius in the collection of the British museum. 8\%. London. I S69. pp. 5, 303, pl. 3.

Refers (p. 109) to a possible relationsbip between Argynnis Diana and the fossil Vanessa Phato. 
Butler, A. G. On fossil butterflies. 4\%. [London. 1873.] pp. 126-28. pl. 48. Butl., lepid. exot., part $\mathrm{xv}$, pp. 126-28, pl. $4^{8} .4^{\circ}$. London. 1873.

Description and illustration of three species, including for the first time Palaeontina oolitica. The figure of the latter was copied into the Graphic of Feb. 22, 1873 , with a brief account of it, under the title, "The oldest fossil butterfly in the world."

Butler, A. G. Notes on the impression of Palaeontina oolitica in the Jermyn street museum. The cover entitled: On a fossil butterfly in the Museum of practical geology, Jermyn street). 80. [London. I874.] pp. 4, pl. Geol. mag., dec. 2, vol. I, pp. $446-49$, pl. 19. 80. London. 1874 .

A rejoinder to Scudder, and in favor of the lepidopterous character of Palaeontina.

Buttner, David Sigismond. Rudera diluvii testes, i. e. zeichen und zeugen der sündfluth; in ansehung des itzigen zustandes unserer erd- und wasser-kugel; insonderheit der darinnen vielfältig auch zeither in querfurtischen revier unterschiedlich angetroffenen; ehemahls verschwemten thiere und gewächse; bey dem lichte natïrlicher weissheit betrachtet; und nebst vielen abbildungen zum druck gegeben. $4^{\circ}$. Leipzig. I710. front., t. p., pl., pp. (6), 314, (20), pl. 30 .

Figures a few insects on plates 16 and 23 , briefly referred to on page 226.

Charpentier, Touissant von. Libellulinae europaeae descriptae ac depictae cum tab. 48 coloratis. $4^{\circ}$. Lipsiae. I840. t.p., pp. I8I, pl. 48.

Under the section De libellulinis petrefactis, pp. $170 \cdot 73$, pl. 48 , the author gives a résumb of what was then known on the subject, and describes and figures some new forms.

Charpentier, T. von. Beschreibung eines Libellulinits aus Kroatien. Neues jahrb. f. miner., 184 I, 332-337, pl. 1. 8\%. Stuttgart. 184i.

Description, figure, and discussion of the affinities of a beautifully preserved dragon-fly's wing from Radoboj.

Charpentier, T. von. Ueber einige fossile insecten aus Radoboj in Croatien. Nova acta acad. Leop.-Carol., 20, i : 399-410, tab. $21-23.4^{\circ}$. Vratislaviae, etc. 1843 .

Descriptions and (poor) illustrations of seven tertiary insects.

Coemans, Eugène. See Van Beneden, P. J. et Coemans, E.

Conybeare, William Daniel and Phillips, William. Outlines of the geology of England and Wales, with an introductory compendium of the general principles of that science and comparative views of the structure of foreign countries; illustrated by a coloured map and sections, \&c. Part 1. [all publ.] 80. London. 1822. pp. (8), 6r, (r), 470, map, tables, pl. of sections.

Brief mention of coleopterous remains in the calcareous slate of Stonesfield (oolite) will be found on pp. 207-209.

Cope, Edward Drinker. Report on the vertebrate paleontology of Colorado. Ann. rep. U.S. geol. surv. terr., $1873,427-533$, pl. 1-8. 80. Washington. 1874 .

On pp. 439-40 he refers to the horizon of the insect-bearing "Green-river" shales, and records "iosects and their larvae" - some of the latter "nearly an incb long, and others minute and in prodigious numbers" - from Fontanelle Creek, and the "east side of Green River above the mouth of Labarge Creek."

Cope, E. D. A contribution to the knowledge of the ichthyological fauna of the Green River shales. Bull. U. S. geol. surv. terr., 3:807-819. 80. Washington. 1877 .

He announces on p. 807 the discovery of fossil insects " near the mouth of Labarge Creek," Wyoming Territory, and at another locality "nearer the main line of the Wasatch Mountains."

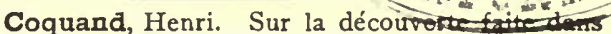
les plâtrières d'Aix d'une grenouille fossile. Bull. soc. géol. France, [2], $2: 383-386.80$. Paris. 1845 .

Announces also the occurrence of insects in the same locality, and reviews what is known of them from the papers of Boisduval and Curtis.

A notice, not seen, will be found in Froriep's Neue notizem $37: 33-36.4^{\circ}$. Erfurt. $18+6$.

Corda, August Karl Joseph. Ueber den in der steinkohlenformation bei Chomle gefundenen fossile scorpion. Verhandl. gesellsch. vaterl. mus. Böhm., vers. $13: 35-43$, pl., figs. I-1 4. 80. Prag. 1835 .

Contains $a$. Urtheil der commission bei der naturforscherversammlung in Stuttgard, pp. 35-36. b. Mikroskopische untersuchung, abbildung und beschreibung von Corda, pp. 36-43, with a detailed description and discussion of the affinities of the insect.

Corda, A. K. J. Ueber eine fossile gattung der afterscorpione. Verhandl. gesellsch. vaterl. mus. Böhm., vers. I7 : 14-18, pl. 1, figs. 1-9. 80. Prag. 1839 .

Description of Microlabis sternbergii. An abstract will be found in the Neues jahrb. f. miner., 1841, 854-55. $8^{\circ}$. Stuttgart. 184I.

Cornelius, C. Ueber termiten. Verh. naturh. ver. preuss. Rheinl. Westph., 14:20-44. 8०. Bonn. I8 57 .

Contains, pp. $40-44$, a letter from Dr. Hagen, criticising the treatment of the fossil Termites in Goldenberg's paper in Palacontographica.

Costa, Achille. See Hope, F. W.

Cotta, Bernhard. Ueber Julus terrestris, als jungendliche versteinerung. Neues jahrb. f. miner. 1833, 392-394, pl. 5. 80. Stuttgart. 1833.

Description and figure of this species as found fossil near Dresden in kalksintergänge in gne iss. Münster, loc. cit., p. 68 speaks of these as Lituiten-artige röhre.

Croizet, (l'abbe). Mémoire sur des débris fossiles de l'Auvergne. Analyse. Bull. soc. géol. France, 4 : 22-26. 80. Paris. 1833 .

Refers briefiy, p. 25, to the Indusia tubulata of Anvergne.

Croizet, (l'abbé). Indications des fossiles de diverses natures qu'on trouve dans la montagne de Gergovie, avec les couches qui leur servent de gisement. Bull. soc. géol. France, 7 : 104-106. 8०. Paris. 1836 .

Merely mentions the occurrence of insects at Merdogne, p. 106. Noticed in Newes jakrb. mineral., $1836,626-27.80$. Stuttgart. 1826 .

Croizet, (l'abbé) et Jobert (ainé). Recherches sur les ossemens fossiles du département du Puy-de Dome. $4^{\circ}$. Paris. 1828. pp. (8), 224, (2), map, sect. 8, pl. 48 in several series.

Refers, p. 25, to the occurrence of Indusia tubulata in the calcareous marls of the Auvergne tertiaries.

Cronstedt, (Axel Fredric). An essay towards a system of mineralogy. Translated from the original Swedish with notes by Gustav von Engestrom. To which is added a Treatise on the pocket laboratory, containing an easy method, used by the author, for trying mineral bodies, written by the translator. The whole revised and corrected, with some additional notes, by Samuel Mendes $\mathrm{Da}$ Costa. 160. London. 1780. t. p., pp. 36, 329 .

Refers, p. 264, to fossil insects found in the alum slate at Andrarum in Skone; I also find p. 257 of the "old ed." referred 1o, but have neither been able to examine it nor the origioal Swedish.

Curtis, John. Observations upon a collection of fossil insects discovered near Aix in Provence, in the suminer of 1828 , by R. J. Murchison and Charles Lyell. Murch.-Lyell, Tert. fresh water form. Aix. $p p$. 9-13, pl. 6. 8o. Edinburgh. 1829. 
Edinb. new phil. journ., 7, pp. 293-297, pl. 6. 8०. Edinburgh. I829.

A list, with occasional brief descriptions, of forty-seven species; the first important notice of the Aix iosects.

Curtis, J. See also Lyell, C.; Murchison, R. I. ; and Murchison, R. I., and Lyell, C.

Czech, Carl. Ueber die entwickelung des insectentypus in den geologischen perioden. Programm realschule Düsseldorf, 1858, I-I4. I60. Düsseidorf. I 858 .

Mainly devoted to showing that the insects of the carboniferous period were not less completely developed than the existing forms.

Dale, James Charles. Notes on some libellulae. Ann. mag. nat. hist., 9:257-58. 80. London. I842.

Suggests that "Aeshna liassina" Strickland is nearer Cordulegaster or Petalura.

Dalman, Johann Wilhelm. Om insekter inneslutne i copal; jemte beskrifning på några deribland förekommande nya slägten och arter. 80 . Stockholm. 1826. Kongl. vetensk.-acad. handl., I 825, 375-4I I, tab. 5. 8o. Stockholm. 1826 .

Describes several new genera and species of insects found in African gum copal. Separate copy not seen. See also Lucas, $H$.

ABSTRACT: Des insectes renfermés dans les résines de copal. Ferr., Bull. sc. nat., 14: 287-290. 80. Paris. 1828 .

A very full abstract including descriptions of the species, signed D. (Desmarest?)

ABSTRACT: On insects enclosed in copal. Quart. journ. sc. lit. arts, 1828, 227-228. 80. London. 1828 .

Briefer abstract of same.

Dana, James Dwight. Fossil larve in the Connecticut River sandstone. Amer. journ. sc. arts, [2], 33 : 45I-452. 80. New Haven. 1862.

Quotes an opinion from Dr. J. L. Leconte that Hitchcock's figure of Mormolucoides articulatus resembles the larva of an ephemerid; and the consequent wish of Dr. E. Hitchcock that the name should be changed to Palephemera mediacra.

Dana, J. D. On fossil insects from the carbonif erous formation in Illinois. Amer. journ. sc. arts, (2), $37: 34-35$, figs. $1-2$ in text. 8o. New Haven. 1864.

Description and figures of two neuropterous insects, the first recorded from the American coal formations.

Dana, J. D. Manual of geology; treating of the principles of the science with special reference to American geological history. Illustrated by over eleven hundred and fifty figures in the text, twelve plates, and a chart of the world. Third edition. 80. New York. I880. pp. I4, 9J 2, (4), pl. I2, map.

Insects mentioned on pp. 273, 274, 334-336, 342,343,350,35I, 388, 4r I, 416; many figures of American, especially palaeozoic, species given. The first edition (1862) gave much less space to insects; the second (1874) does not differ from the third, as to insects; the sec
regards the insects.

Dana, J. D. See also Deane, J.

Dandet, Henri. Chenilles fossiles. Petites nouz. entom., 2, no. 145, p. $25.44^{\circ}$. Paris. 1876.

First mention of the discovery of caterpillars at Aix.

Daudet, H. Description d'une chenille fossile trouvée dans le calcaire d'Aix (Provence). Rev. mag. zool., [3], 4: 41 5-24, pl. I7. 80. Paris. 1876.

Describes Satyrites incertus, the first fossil caterpillar of a butterfly known, and discusses its probable affinities.

Davila [Pedro Franco]. Catalogue systématique et raisonné des curiosités de la nature et de l'art qui composent le cabinet de M. Davila. Tome 3. 80. Paris. I767. pp. 6, 290, pl. 8 [in Ist part].

On pp. 223-24. Pétrifications animales de la septième classe. Entomolites.
Dawson, John William. On a terrestrial mollusk, a chilognathous myriapod and some new species of reptiles from the coal formation of Nova Scotia. Quart. jonrn. geol. soc. Lond., 16, i : 268-77, figs. I-29. 80. London. 1859.

Describes and figures $X y$ lobius sigillariae.

Dawson, J. IV. The air breathers of the coal period in Nova Scotia. Can. nat. geol, $8:$ I-I2, 8I -92 , I 59-75, 268-95, pl. I-6. 8o. Montreal. I 863. Same as the following.

Dawson, J. IV. Air breathers of the coal period: a descriptive account of the remains of land animals found in the coal formation of Nova Scotia, with remarks on their bearing on theories of the formation of coal and of the origin of species, with illustrations. 80. Montreal. I863. t. p., front., pp. 4, SI, pl. 6 , and a plate of photogr.

Contains, section xii, Invertebrate air breathers, pp. $62-63$, and pl. 6 (pars) which describes Xylobius sigillariae. See also p. 67.

Dawson, J. WV. On the conditions of the deposition of coal, more especially as illustrated by the coal-formation of Nova Scotia and New Brunswick. Quart. journ. geol. soc. Lond., 22 : 95-169, pl. 5-1 2. 80. London. I866.

Merely refers (p. 145) to the occurrence of a myriapod and cne insect at the Joggins.

Dawson, J. IV. On some remains of palæozoic insects recently discovered in Nova Scotia and New Brunswick. Can. nat., [n. s.], 3: 202-206, 5 woodc. in text. 80. Montreal. 1867.

Geol. mag., $4: 385-88$, pl. 17, figs. 1-5. 80. London. 1867 .

Haplophlebium Barnesii and four of the Devonian insects are described and figured ior the first time by Scudder.

Dawson, J. IV. Acadian geology. The geological structure, organic remains, and mineral resources of Nova Scotia, New Brunswick, and Prince Edward Island. $2 \mathrm{~d}$ edition, revised and enlarged, with a geological map and numerous illustrations. 80. London. 1868. pp. 27, 694, pl. (9), map, figs. 23I, (I) in text.

Pages 386-88, 524-26, figs. 153, 181-84, contain descriptions and jillustrations of carboniferous and devonian insects by Scudder. There is also a Note on the myriapods of the coal formation on pp. 495-96, by the same.

Dawson, J. W. Note on some new animal remains from the carboniferous and devonian of Canada. Quart. journ. geol. soc. Lond., 26, i : 166. 80. London. 1870.

Notices the occurrence of Blattarix from the Nova Scotia coal measures.

Dawson, J. W. Supplement to the second edition of Acadian geology, containing additional facts as to the geological structure, fossil remains, and mineral resources of Nova Scotia, New Brunswick, and Prince Edward Island. 8०. London. I878. pp. 102.

This supplement bound with reissue of $2 \mathrm{~d}$ ed. forms $3 \mathrm{~d}$ ed. Mentions and figures, pp. 53, 55, 56, some carboniferous insects and myriapods which had been described by Scudder since the previous edition.

Deane, James. On the sandstone fossils of Connecticut River. Fourn. acad. nat. sc. Philad., [2], 3: 173-78, pl. is-20. 40. Philadelphia. I8 56.

On pl. Is are figured tracks of what the author presumes are articulated animals, in which he is supported by the opinions, quoted on p. 177, of Professors Leidy, Wyman, and Dana, the latter believing them probably crustacean. Some are possibly the tracks of insects.

Deane, J. Ichnographs from the sandstone of Connecticut River. $4^{\circ}$. Boston. I86r. pp. 6r, pl. 46. 
Contains introduction, pp. 3-4, by A. A. Gould; biographical notice (of Dr. Deane) by H. 1. Bowditch, pp. 5-14; a memoir upon the fossil footmarks and other impressions of the Connecticut River sandstone, by James Deane (compiled by Thomas Tracy Bouvé), with a note by the compiler, p. 17 , and the memoir, pp. 19-32; description of the plates, pp. 33-6r (by Mr. Bouvé).

References to insect tracks are made on p. 26 , and in the descriptions of pl. $40-42$ (pp. 57-58).

Defrance, Jacques Louis Martin. Indusie. Dict. sc. nat., 23: 41 I-I 2. $8^{\circ}$. Paris. I 822.

Notice of the indusial limestone of Auvergne, and the fossil phryganid cases of which it is composed.

Defrance, J. L. M. Insectes (foss.). Dict. sc. nat., $23: 524-26$. So. Paris. I 822.

A review of the older authors, questioning the validity of many of the fossils preserved in the rocks, although accepting those entombed in amber.

Deichmuller. See Geinitz, H. B.

Denton, William. On a mineral, resembling albertite, from Colorado. Proc. Bost. soc. nat. hist. I0: 305-06. So. Boston. I866.

The first account, p. 306 , of fossil insects from the American tertiaries; he speaks only of Diptera in a petroleum shale.

Desmarest, Anselme Gaetano. Insectes dans le succin.

Not seen. Cf. Marcel de Serres in Anis. sc. nat. $15: 102.8^{\circ}$. Paris. 1828. Also Guérin in Dict. class. hist. nat., $8: 580$. 8०. Paris. ${ }^{\circ} 825$

Desmarest, A. G. See also Dalman, J. W.

Desmarest, Eugène. Un morceau de bois fossile...qui ... a présenté des traces qui ont dû être faites par des larves d'insectes. Ann. soc. ent. France, [2], 3, bull., pp. 26-27. So. Paris. I 845 .

Wood bored by larvae of a longicorn beetle.

Desmoulins, Antoine. Découverte d'elytres fossiles de coléoptères. Ferr., bull. sc. nat., $9: 253$. 80. Paris. I 826.

Note upon a locality in the roche calcaire of Mont St. Catherine, near Ronen, where elytra with metallic colors had been found.

Dohrn, Anton. Eugereon Boeckingi, eine neue insectenform aus dem todtliegenden. $4^{\circ}$. Cassel. 1866. t. p., pp. 8, taf. Palaeontogr. I3: 333-40, taf. 41. 8o. Cassel. 1866.

Description and discussion of the affinities of the most remarkable fossil insect yet discovered, considered here to unite the Hemiptera and Neuroptera.

Dohrn, A. Zur kenntniss der insecten in den primärformationen. Palaeontogr., I6: 129-34, taf. 8 . $4^{\circ}$. Cassel. I867.

Further discussion of Engereon and description of two new carboniferons insects; for a number of the earlier insects a new order, Dictyoptera, is for the first time proposed.

Dohrn, A. Eugereon Boeckingi und die genealogie der arthropoden. Stett. entom. zeit., 28 : 145I 53, pl. I [4I]. 8o. Stettin. 1867.

Fuller discussion of the affinities of Eugereon and its bearings on Haeckel's views of the genealogy of insects.

Dohrn, A. Julus Brassi n. sp. ein myriapode aus der steinkohlenformation (with note by IVeiss). Verhandl. naturh. ver. preuss. Rheinl. u. Westph., [3], 5: 335-36, pl. 6. 80. Bonn. I 868 .

Description of a species from Lebach with memoranda of previously described species. The note by $W$ eiss is purely geological, on the probable equivalence of the Lebach beds and those yielding Xylobius.

Doubleday, Edward, and Westwood, John Obadiah. The genera of diurnal lepidoptera; comprising their generic characters, a notice of their habits and transformations, and a catalogue of the species of each genus; illustrated with 86 plates, by William C. Hewitson. 2 vols. fol. London.
I 846-52. Vol. I, pp. I2, 250, (2), pl. A., I-30 Vol. 2, t. p., pp. 25I-534, pl. 3I-80 and suppl. pl.

Several numbers on the plates are repeated, followed by "A." A single fossil species, Cyllo sepulta, is catalogued on p. $36 \mathrm{r}$.

Duisburg, H. von. Zur bernstein-fauna. Schriften $k$. phys.-ökon. gesellsch. Königsb., 9:23-28, fig. $4^{\circ}$. Königsberg. I 868 .

Discusses the systematic position of the smallest amber insect known, a species of the hyınenopterous genus Mymar, the expanse of whose wings is scarcely more than half a millimetre.

Duponchel, [Philogène Auguste Joseph.]. L'existence d'une impression très-remarquable de lépidoptère fossile, qui a été trouvée dans une plâtrière des environs d'Aix (en Provence). Ann. soc. ent. France, 7, bull. ent., pp. 51-52. 80. Paris. 1838 .

First announcement of Neorinopis as a "Nymphale"; reproduced in Scudder's Fossil butterfices, p. 15.

Faton, Alfred Edwin. A monograph on the ephemeridae. Trans. entom. soc. Lond., I 87 I, 1-164, pl. 1-6. 80. London. I87 I.

Contains a chapter on Fossil ephemeridae, pp. $3^{8-40}$, and a a figure, pl. I, fig. 10, of a single unnamed species from Solenhofen.

Eaton, A. E. Did flowers exist during the carboniferous epoch? Nature, 20: 31 5. $4^{\circ}$. London. I879.

Breyeria is an ephemerid.

Translation. - Der angebliche steinkohlenzeitschmetterling. Kosmos, 5: 46I-62. 80. Leipzig. I879.

Edwards, William Henry. The butterflies of North America. 40. New York. 1868-72. pp. (Io), 2, (I 54), pl. (50). Contains also a Synopsis of North American butterflies, pp. 5, 52 ; and a Supplementary part, pp. (17), pl. (3), and corrected pp. 4-1 2, I9-20 of synopsis.

p. (64) in pt. I (1868) contains a figure of Mylothrites Pluto, with suggestions concerning its affinities with the living $A$ rgynis Dicna.

Ehrenberg, Christian Gottfried. Eine sammlung bei Brandenburg aufgefundener bernsteinstïcke. Froriep, Neue notizen geb. nat.-heilk., I9: I20. $4^{\circ}$. Weimar. I $84 \mathrm{I}$.

Refers to insects of the genera Ceratopogon and Gryllus and to Phyganidae and ants. Notice of same in Neues jahrb. mineral., I $843,502 . \quad 80$. Stuttgart. 1843 .

d'Fichwald, Edouard. Sur un terrain jurassique a poissons et insectes d'eau douce de la Sibérie orientale. Bull. soc. géol. France, [2], 21 : 19-25. 80. Paris. I864.

Describes Ephemeropsis trisetalis, pp. 21-22. The deposit was thought by Muilier to be Eocene.

Translation. - On a jurassic deposit containing fresh-water fish and insects in Eastern Siberia. Quart. journ. geol. soc. Lond., 20, ii : $21-22$ (Abstract by $\mathrm{R}$. T.). So. London. I864.

d'Eichwald, E. Ueber fossile insecten und belemniten. Amtl. ber. vers. deutsch. naturf., 39: 169-72. $4^{\circ}$. Geissen. I865.

Notices, p. 170, the ephemerid larva described by him as Ephemeropsis, found in calcareous schists on the banks of the Turga in Siberia.

d'Fichwald, E. Lethaea rossica, ou Paléontologie de la Russie décrite et figurée. text, $8^{\circ}$. atlas, $4^{\circ}$.

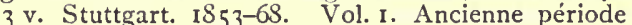
(in 2 parts), pp. I-I $9,17-26, \mathrm{I}-68 \mathrm{I}, 68 \mathrm{I}-\mathrm{I} 657$ + titles to parts. I860. Atlas. t. p., pp. 8, tab. 59. I8 59. - Vol. 2. Période moyenne (in 2 parts), pp. I-35, I-640, 64I-I 304 + titles to parts. I 865, I 868. Atlas. t. p., tab. 40 , expl. of plates opp. plates. 1868 . - Vol. 3. Période moderne, pp. 19, 533. I 853. Atlas. t. p., pp. 4, tab. I 4, expl. of plates opp. plates. 1853 . 
The insects are contained in vol. 2, ii., pp: $\{191-95$, tab. 37 (1868).

Elrod, M. N., and McIntire, E. S. Report of a geological survey of Orange county. Ann. rep. geol. surv. Ind., $7: 203^{-239}$. 80. Indianapolis. I 876.

The geological position of Paolia z'etusta is shown on pp. 206, 221 .

Erichson, IVilhelm Ferdinand. Zur abbildung der libelle von Solenhofen. Buch, Fura in Deutschl. f. 135, pl. (3.) Abhandl. kön. akad. wiss. Birlin, 1837 , phys. abhandl. 4\%. Berlin. 1839.

Considers the insect figured by von Buch as partaking of the characters of the genera Aeschna and Libellula. It was afterwards named A nax Buchi by Hagen.

Eser, Anton Friedrich. Das petrefactenlager bei Ober-und Unter-Kirchberg an der Iller im oberamt Laupheim. Fuhresh. ver. vaterl. naturk. Wiirtt., $4: 258-267$. 8०. Stuttgart. 1849 .

Records, pp. $264-265$, the discovery of two insects in the miocene fish beds of Unterkirchberg.

Esper, Eugen Johann Christoph. Ad avdiendam orationem pro capessendo munere philosophiae professoris pvblici extraordinarii a rectore academiz... Christiano Friderico Carolo Alexandro ... gratiosissime sibi collato d. martii, 1733 recitandam omni qva decet observantia invitat simvlque de animalibus oviparis et sanie frigida praeditis in cataclysmo qvem svbiit orbis terrarum plerisque salvis disserit Evgen. Joann. Christoph. Esper. $4^{\circ}$. Erlangae. 1783. pp. 20.

Refers in a general way to fossil insects, pp. 18-rg.

Evans, C. E. Insect remains in the Paludina beds at Peckham (with note concerning them by F. Smith, as recorded in a letter from H. Woodward). Geologist, $4: 39-40$, fig. 80. London. I86I.

Figures an elytron and mentions others.

Fairmaire, Léon. See Millière, P.

Faujas-de-Saint-Fond, Barthélemy. Nouvelle notice sur les plantes fossiles renfermées dans un schiste marneux des environs de Chaumerac et de Roche Sauve, département de l'Ardèche. Mém. mus. hist. nat., 2 : 444-459, pl. I 5. $4^{\circ}$. Paris. ISI 5.

Gives the opinion of Latreille on a species of "Polistes" figured on the plate.

Feistmantel, Karl. Die steinkohlen becken in der umbegung von Radnic. Archiv. naturv. landes. durchf. Böhmen, bd. I, sect. 2, at end, pp. I-120, pl. I-2. 8o. Prag. I869.

Gives, p. 66, a brief account of the Chomle scorpions described by Corda, and notices the discovery of Palaranea borassifolia vithout description.

Fischer, Leopold Heinrich. Orthoptera europaea. $4^{\circ}$. Lipsiae. I853. pp. 20, 454, tab. I8.

Species fossiles, pp. 55-57, contains a bibliography of fossil orthoptera and a list of the species.

Fisher, Osmond. On the brick-pit at Lexden, near Colchester. Quart. journ. geol. soc. Lond., 19: 393-400. 3o. London. 1863.

Under the head of Organic remains, pp. $398-400$, a letter is printed from $\mathrm{T}$. V. Wollaston concerning Coleoptera found in the pit, and deductions are drawn concerning the climate of the time in which they lived.

Fischer von Waldheim, Gotthelf. Prodromus petromatognosiae animalium systematicae continens bibliographiam animalium fossilium. $4^{\circ}$. Mosquae. 1826. Nouv. mem. soc. imp. nat. Mosc., I : 30I-374; 2 : 95-277, 447-458. $4^{\circ}$. Moscou. 1829-32. 458 .
Fischer von Waldheim, G. Bibliographia palaeonthologica animalium svstematica editio altera aucta. Sুo. Nosquae. I\$34. t.p., pp. 8, 414.

Contains slight additions to the preceding, with the notices on pp. 305, 372 .

Fleck, Hugo. See Geinitz, H. B., Fleck, H., und Hartig, E.

Fletcher, John. A dreadful phenomenon described and improved; being a particular account of the sudden stoppage of the river Severn, and of the terrible desolation that happened to the birches between Coalbrook Dale and Buildwas Bridge in Shropshire on Thursday morning, May 27, 1773 . Works of Fohn Fletcher, Vicar of Madeley, I : 229246. 1 20. London. [1773?]

On p. 237 " a great many [fossils] were found bearing the impression of a flying insect, not unlike the butterfly into which silk-worms are changed."

Fliche, P. Sur les lignites quaternaires de Jarville près de Nancy. Comptes rendus, 80: 1 233-1 236. $4^{\circ}$. Paris. 1875 .

Records, p. 1234, seven kinds of beetles, northern species affecting moist localities, p. 1236 .

Fliche, P. Faune et flore des tourbières de la champagne. Comptes rendus, $82: 979-982$. $4^{\circ}$. Paris. 1876 .

Notices the occurrence, p. 979, of four species of beetles from Vaunes.

Fologne, Egide. See de Borre, A. P.

Fontaine, William Morris and White, J. C. The permian or upper carboniferous flora of West Virginia and S. W. Pennsylvania. $8^{\circ}$. Harrisburg. I88o. Rep. progr. second geol. surv. Penn., PP, pp. Io, 143 , map, pl. 38 .

Contains a description, p. 104, and a figure, pl. 38 , figs. $5,5^{\mathrm{a}}$, of Gerablattina balteata by S. H. S[cudder].

Fothergill, John. An extract of John Fothergill ... his essay upon the origin of amber. Phil. trans., $43: 21-25.44^{\circ}$. London. I746.

Mentions the occurrence in amber, of "ants, spiders, \&c."

Frič, Anton. See Fritsch, A.

Fritsch, Anton. Palaeontologische untersuchungen der einzelnen schichten in der böhmischen kreideformation. Archiv. naturw. landesdurchf. Böhanen, bd. I, sect. 2, pp. 181-256, pl. 3. 80. Prag. 1869 .

Refers on p. 187 to the discovery of an elytron of a beetle, and a tube of a phryganid larva in clay-schists at Kounic.

Fritsch, A. Notiz über eine heuschrecke aus der braunkohle von Freudenhain. Archiv. naturw. landesdurchf. Böhmen, bd. I, sect. 2, p. 276, fig. 8०. Prag. 1869

Describes and figures Decticus umbraceus.

Fritsch, A. Fauna der steinkohlen formation Böhmens. Archiv naturw. landesdurchf. Böhmen, bd. 2, abth. 2, th. I, pp. I-16, pl. I-4. 80. Prag. 1874.

Describes Palaranea borassifoliae for the first time, and gives new figures and descriptions of four previously known insects, including the famous scorpions described by Corda.

Fritsch, A. Fauna der gaskohle und der kalksteine der permformation Böhmens. Bd. I. heft I. 40. Prag. 1879. pp. 92, taf. I 2.

Contains pp. 26-31: "Vorläufige vebersicht der in der gaskohle und den kalksteinen der permformation in Böhmen vorgefundenen thierreste." On p. 31 appears a list of five insects, to three of which (myriapoda) names are given, from Nyran and Kounová.

Fritsch, A. Dva noví členovci z útvaru kamenouhelného v Cechách. Vesmir, 9 : 24I-242, figs. A, B. $4^{\circ}$. Praha. I880.

Popular account of interesting remains of Ephemeridae from the carboniferous schists of Votvovic. 
Fromont, [Louis]. [Empreintes sur une plaque de pierre lithographique.] Ann. soc. ent. belg., 23, comles rendus, p. 35. 80. Bruxelles. I 880.

Mention of impressions considered to resemble the antennae of an insect.

de la Fruglaye. Extrait d'une lettre de M. de la Fruglaye à M. Gillet-Laumont, sur une forêt sousmarine qu'il a découverte près Morlaix (Finistère) en I8I1. Fourn. des mines, $30: 399-91$. 8o. Paris. I8I I.

Notices a fossil chrysalis and a fly.

Gada, Pehr Adrian. Rön och undersökning, i hvad man insecter och zoophyter bidraga til stenhärdningar. Kongl. s'et. acad. nya handl. 8 : 98-106. 160. Stockholm. 1787 .

Refers pp. 103-104 to "globuli arenacei" which he considers apparently as eggs of insecis.

Gaudin, Charles Théophile. See Heer, O.

Geikie, James. Prehistoric Europe; a geological sketch. 8o. London and Philadelphia. $188 \mathrm{I}$. pp. 18, 592, pl. 5 .

Refers to notices of pleistocene insects on pp. 54, 256, 299, 440, 480, 494 .

Geinitz, F. Eugen. Versteinerungen aus dem brandschiefer der unteren dyas von Weissig bei Pillnitz in Sachsen. 80. Stuttgart. I873. pp. I4, pl. Neues jahrb. f. miner., I873: 691-704. taf. 3 . 80. Stuttgart. 1873 .

Describes two Blattinae and a Fulgorina.

Geinitz, F. E. Ueber neue aufschlüsse im brandschiefer der unteren dyas von Weissig bei Pillnitz in Sachsen. 80. Stuttgart. 1875. pp. 14, pl. Neues jahrb. f. miner., 1875, I-I 4, taf. I. 80. Stuttgart. 1875 .

II. Insecten, pp. 4-6; describes four species of Blattina, one of them as new.

Geinitz, F. E. Die blattinen aus der unteren dyas von Weissig bei Pillnitz. $4^{\circ}$. Halle. I 880. pp. 22, pl. r. Nova acta k. Leop-carol.-deutschen akad. naturf., 41 , ii. no. 7. $4^{\circ}$. Halle. 1880.

Gives a full description, with figures of the diversity in neuration in opposite wings, of a species of cockroach, together with criticisms of Scudder's Palaeozoic cockroaches, and noles and figures of seven other forms.

Geinitz, F.E. Der jura von Dobbertin in Mecklenburg und seine versteinerungen. Zeitschr. deutsch. geol. gesellsch., I880, 510-535, taf. 22. 80. Berlin. 1880 .

Contains, pp. 519-531, Insectenfauna des dobbertiner unteren jura, in which seventeen insects are described, the greater part of them new. The plate is wholly devoted to insects.

Geinitz, Hanns Bruno. Charakteristik der schichten und petrefacten des sächsischen kreidegebirges. $4^{\circ}$. 1839-42. Dresden und Leipzig. pp. 4, 116, 26, pl. A, 24.

Under the head of Insecten, pp. 12-13, taf. 3-6, are described and figured boriogs of insects which the author, supported by Reichenbach and Germar, refers to Cerambycidae, and describes under the generic appellation Cerambycites. Dr. Geinitz informs me that these belong to Gastrochaena amphisbaena Goldf., a burrowing mollusk.

Geinitz, H. B. Grundriss der versteinerungskunde. 80. Dresden und Leipzig. 1845 [also dated 1846]. pp. I0, 8I 5, pl. 8, tabelle I.

B. Arthrozoa, pp. 179-93, pl. 8 ; gives a brief general systematic account of fossil insects, with descriptions of a few forms and figures of Aeschra longiolata aud Oedipoda melanosticta. The second edition, $8^{\circ}$, Leipzig, 1856, not seep; according to Hagen the insects are upon pp. $179-90$.

Geinitz, H. B. Die versteinerungen der steinkohlenformation in Sachsen. fo. Leipzig. 1855 . pp. $7,6 \mathrm{r}, \mathrm{pl} .35$.
Insecta, pp. $1-2$, pl. 8 , figs. 1,4 , are represented only by borings of supposed coleoptera.

Geinitz, H. B. Ueber einige seltene versteinerungen aus der unteren dyas und der steinkohlenformation. Neues jahrb. f. miner., 1865, 385-394, taf. 2,3 .

Describes Ephemerites Rückerti and contains a letter upon the same from Dr. Hagen.

Geinitz (H. B.). Paläontologische mittheilungen aus dem mineralogischen museum in Dresden. Sitzungsb. naturw. gesellsch. Isis, 1872, 125-131, taf. I. 8o. Dresden. 1872.

Contains, pp. 128-3r, taf. I, fig. 4-7: iii. Fossile myriapoden in dem rothliegenden bei Chemnitz. Palaeojulus dyadicus is described.

Geinitz, H. B. Ueber Palaeojulus dyadicus. Neues jahrb. $f$. miner., 1878, 733. 8o. Stuttgart. 1878 .

In response to Sterzel, defends the myriapodan character of Palaeojulus. The identity of his Palaeojulus with Scolecopteris elegans Zenk. is acknowledged by the author in 1880 . See his Nachiraege zur Dyas, I. Witth. k. min. geol. prackist. mus. Dresden. Heft. 3,1-4. $4^{\circ}$. Cassel. $1880^{\circ}$

Geinitz, H. B. Bericht über die ... auf dem reviere des carlschachtes der Lugau-Niederwürschnitzer steinkohlenwerke gesammelten steinkohlenpflanzen. Sitzungsb. naturv. gesellsch. Isis, 1879, 7-13, taf. 1. 80. Dresden. 1879.

Describes, with Deichmüller, p. 12-13 (two figures in text), Blattina dresdensis from the coal-beds near Klein-Opitz, Saxony.

Geinitz, H. B., Fleck, H., und Eartig, E. Die steinkohlen Deutschland's und anderer länder Europa's, ihre natur, lagerungs-verhältnisse, verbreitung, geschichte, statistik und technische verwendung. 2 bd. $4^{\circ}$. München. I865. Bd. I (also entitled: Geologie der steinkohlen Deutschland's und anderer länder Europa's, mit hinblick auf ihre technische verwendung; von Geinitz). pp. Io, 420 , atlas, ff. 3 , pl. 28. Bd. 2 (also entitled: Geschichte, statistik und technik der steinkohlen Deutschland's und anderer länder Europa's ; von Fleck u. Hartig). pp. $8,423,(4)$, map.

Contains (bd. 1, pp. 146-50) Organische ueberreste der steinkohlenformation des Saarbrückenschen, in which, pp. 149, 150 appear lists of the carboniferous and dyas insects of the basin of the Saar.

Geinitz, H. B. und Gutbier A. von. Die versteinerungen von Obersachsen und der Lausitz. Gein., Gäa von Sachsen. 80. Dresden and Leipzig. I 843 , pp. 6I-r 42 .

Insects at pp. 66, 115, 140; nothing new.

George, Hector. See Brongniart, C.

Germar, Ernst Friedrich. Insecten in bernstein eingeschlossen, beschrieben aus dem academischen mineralien-cabinet zu Halle. Germar, Mag. d. entom. I : I I-18. 80. Halle, I8I3.

Describes seven insects of various suborders.

Germar, (E. F.). Fauna insectorum Europæ. Fasciculus undecimus. Insectorum protogeae specimen, sistens insecta carbonum fossilium. Long, minute fol. Halæ. 1837. 2 t. p., 1 f., index, pl. 1-25.

Each plate contains one page of descriptive text, unpaged. The insects are all from the iertiaries.

Germar, E F. Ueber die versteinerten insecten des juraschiefers von Solenhofen aus der sammlung des grafen zu Münster. Oken, Isis. 1837, 421424. 40, Leipzig. I 837 .

Germar compares the few insects then known from Solenhofen with the tertiary insects, and concludes that: 10 , none of the jurassic species are identical with the living; 20 , there are no strikingly strange forms; $3^{\circ}$, the general facies of the fauna is that of middle Europe and the United States, and indicates a 
similar climate $; 4^{\circ}$, all are wood or leaf eaters, excepting some water betetles and a Geotrupes. This paper appears to have been read betore the Jena meeting of the Deutscher natursforscher und aertzte, in $1 S_{3} 6$, but $I$ have been unable to consult the report of that meeting.

Germar, E. F. Die versteinerten insecten Solenhofens. Sova acta acad. Leop.-Carol. 19, i. : IS7-222, tab. $21-23 \cdot 4^{\text {to }}$. Vratislaviae et Bonnae, I\$39.

Describes and rudely figures seventeen insects of various orders, of which eleven are credited to Münster. The descriptions are preceded by some general remarks, listorical and otherwise, upon Solenhofen and other fossil insects.

Germar, E. F. Beschreibung einiger neuen fossile insecten (i) in den lithographischen schiefern von liavern und (ii.) in schieferthon des steinkohlengebirges von Wettin. Münst., Biitr. z. petref., hift 5, ff. 79-94, taf 9, 13. $4^{\circ}$. Bayreuth. IS42.

The first part, pp. $79-90, \mathrm{pl} .9,13$, describes and figures nine insects of various orders trom Solenhofen, being the first memoir on the subject. The second, pp, $\infty-04, \mathrm{pl}, 13$, describes and figures four cockroaches and one orthopteron from the coal measures. See also Voigt.

Germar, E. F. Ueber einige insekten aus tertiärbildungen. Zeitschr. deutsch. geol. Gesellsch., i : 5266, taf. 2. So. Berlin. IS49.

Describes and figures six beetles, a fly and a bee from the Rhine and Aix. Briefty moticed in Neuesjahrb. mineral., 1851, 759. $8^{\circ}$. Stuttgart. $185 \mathrm{I}$.

Germar, (E. F.). Die versteinerungen des steinkohlengebirges von Wettin und Löbejün in Saalkreise. Also entitled : Petrificata stratorum lithanthracum Wettini et Lobejuni in circulo Salae reperta. fo, 8 hefte [fasc.] Halle, I844-53. pp. 4, I I6, taf. [tab.] 40. Ies heft, pp. i.-iv., I-I 2, pl. I-5, I 844 ; zes heft,

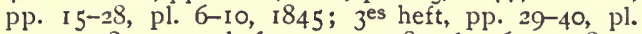

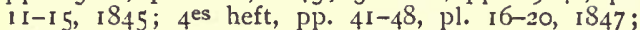
$5^{\text {es }}$ heft, pp. 49-60 (59), pl. 21-25, 1 848 ; Ges heft, pp. 6I-So, pl. 26-3o, I 849 ; $7^{\text {es }}$ heft, pp. $8 \mathrm{I}-102$, pl. 3I-35, I85I; Ses heft, pp. I03-116, pl. 36-40, I 853 .

Ueberreste von insekten [Insectorum vestigia], pp. $81-\$ 8$, taf. 31,39 (1951), almost entirely devoted to the cockroaclies of the palaeozoic rocks, on which it is the first important publication.

Germar, E. F. See also Geinitz, H. B.

Germar (E. F.) und Berendt, (G. C.). Die im bernstein befindlichen hemipteren und orthopteren der vorwelt. fo. Berlin. I856. t. p., pp. 2, 40, pl. 4. Berendt, Bernst. befindl. org. restevorw. 2 er bd. ie abth.

Edited, with notes, by Hagen : sixty Hemiptera and eight Orthoptera are described and figured, the latter in part by Pictet.

Gerstaecker, Carl Eduard Adolph. Die klassen und ordnungen der arthropoden wissenschaftlich

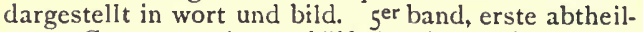
ung. Crustacea (erste hälfte) mit so lithographirten tafeln. 8०. Leipzig und Heidelberg. IS66-79. Also entitled: Die klassen und ordnungen des thierreichs wissenschaftlich dargestellt in wort und bild. Von Dr. H. G. Bronn. Fortgesetzt von $\Lambda$. Ger-

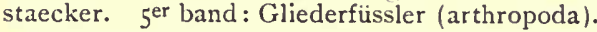

Contains in the introduction to the arthropoda in general: viii. Zeitliche verbreitung, divided into : 1 . Allgemeiner charak ter der tossilen arthropoden, pp $287-293$. Aufeinanderfolge der formen in den verschiedenen erdschichten, pp. 293-295. Published in 1966? Under the first section the author notices the extremely smail number of known fossil forms as compared with living types, and their almost complete typical agreement with existing forms ; insisting that even the oldest not only fall into the orders, but even into the families of insects now extant.

Gerstaecker, C. E. A. See also Packard, A. S.; and Scudder, S. H.

Gervais, Paul. See de Borre, A. P.

Giard, (Alfred). Un papillon dans la houille; note de M. Preudhomme de Borre. Bull. scient. hist. et litt. clép. Nord, ann. 7, no. 6-7, pp. 121-127. So. Lille. IS 75 .

Discusses the affinities of Breyeria, concluding that it is not a lepiclonteron but beiongs to the Archiptera.

Giard, A. Note sur un diptère nouveau pour la faune française (Penthctriı holosericea Meig.) suivie de quelques remarques sur les bibionides fossiles. Bull. scient. hist. litt. dép. nord, ann. 8, pp. 172-173. So. Lille. I876.

Discusses, pp. ${ }^{277-79}$, the Penthetria Vaillantii of Oustalet from Auvergne. Continued in the following.

Giard, A. Note sur les bibionides fossiles. Bull. scient. dép. nord [2] I : I2-16. So. Lille. 1878 .

Criticises the classification by Oustalet and Brongniart of various species placed by them in Protomyia. A continuation of the preceding.

Giard, A. Les coléoptères fossiles d'Auvergne par M. Uustalet; remarques critiques. Bull. scient. dép. Nord, [2], I : 56-62, 109-1 18. So. Lille. I878.

A sharp criticism of Oustalet's memoir on the fossil insects of Auvergne; the Neuroptera as well as the Coleoptera are discussed.

Giard, A. See also de Borre, A. P.; Oustalet, E. ; and de Saporta, G.

Giebel, Christoph Gottfried. Paläozoologie; entwurf einer systematischen darstellung der fauna der vorwelt. $8^{\circ}$. Merseburg. I846. pp. 8, 360 .

The insects, mentioned only by generic names, are systematically treated under each period: the period of water life on pp. $53-59$, the transition period on pp. $144-143$, and the period of land and air life on pp. 265-288.

Giebel, C. G. Gaea excursoria germanica; Deutschlands geologie, geognosie und paläontologie als unentbehrlicher leitfaden auf excursionen und beim selbststudium. I $6^{\circ}$. Leipzig. I $34^{8}$ pp. 8 , 5 IO, (24), taf. 24 .

Brief mention of insects on pp. $160,266,323,442$. Blattina didyma is figured on $\mathrm{pl} .5$, fig. 26 .

Giebel, C. G. Ueber insectenreste im wettiner steinkohlengebirge. Fahresb. naturw. ver. Halle, 2 : S-9. 80. Berlin. 1850.

Mention of the cockroaches described by Germar.

Giebel, C. G. Bericht über die leistungen im gebiete der paläontologie mit besonderer berücksichtigung der geognosie während der jahre 1848 und I849. 8o. Berlin. I851. pp. (4), $28 \mathrm{I}$.

5. Insecten, pp. $92-05$, is mostly taken up with a notice of the first volume of Heer's Oeningen insects.

Giebel, (C. G.). Deutschlands petrefecten; ein systematisches verzeichniss aller in Deutschland und den angrenzenden ländern vorkommendęn petrefacten, nebst angabe der synonymen und fundorte. 80. Leipzig. I852. pp. 13, 706.

Arachnoidea, pp. 634-636; Insecta, pp. 636-656. A simple list.

Giebel, C. G. Allgemeine palaeontologie; entwurf einer systematischen darstellung der fauna und flora der vorwelt; zum gebrauche bei vorlesungen und zum selbstunterrichte. 8o. Leipzig. I 852 . pp. 8,413 .

Insects treated on pp. $117-118,204-208,276-236$ under the same general divisions as in the author's Paläozoologie. The genera are enumerated.

Giebel, (C. G.). Beiträge zur palaeontologie. 8o. Berlin. 1853. pp. 4, 192, pl. 3. Fahresb. naturw. ver. Halle, 5: 287-478. 8o. Berlin. 1853.

Contains: i. Die palaeontologie Deutschlands auf ihrem gegenwärtigen standpuncte, pp. $1-71\left[29_{7}-357\right]$. A tabular view of the genera found in Germany with the number of species of each includes, pp. 63-66 [349-352], the insects, 169 genera, and 377 or more species.

vericht über den fortschritt der paläontologie während der jahre $1850-52$, pp. 109-192. Contains an analysis of the literature on fossil insects on pp. 124-126 [410-412]. 


\section{A BIBLIOGRAPHY OF FOSSIL INSECTS:}

Giebel, (C. G.) Die insecten und spinnen der vorwelt mit steter berücksichtigung der lebenden insecten und spinnen; monographisch dargestellt. Also entitled : Fauna der vorwelt mit steter berücksichtigung der lebenden thiere. $2^{e r}$ band: Gliederthiere; erste abtheilung: Insecten and spinnen. 80. Leipzig. 1856. pp. I8, 511 .

A systematic treatment of all the fossil insects then known with descriptions of nearly all; many are described and named for the first time from published plates. Notice especially the treatment of the illustrations of Brodie's fossil insects of England. Some new amber insects also appear.

Giebel, C. G. Insectenreste aus den braunkohlenschichten bei Eisleben. Zeitschr. gesammt. na-

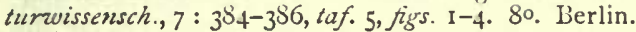
I 556.

Describes and figures four insects, - two coleoptera, one cockroach, and one dragon-tiy, - to only one of which, Buprestites Minnae, a name is given.

Giebel, C. G. Geologische uebersicht der vorweltichen insecten. Zeitschr. gesammt. naturw., 8: 174-1\$8. So. Berlin. I\$56.

A general review of authorities, with lists of the species mentioned in their works.

Giebel, C. G. Zur fauna des lithographischen schiefers von Solenhofen. Zeitschr.gesantmt. naturw, $9: 373-388$, taf. 5-6. So. Berlin. I8 57 .

Contains long descriptions and figures of two dragon-flies.

Giebel, (C. G.). Eine neue aeschna aus den lithographischen schiefer von Solenhofen. Zeitschr. gessammt. naturw., 16: 127-131, taf. 1. 80. Berlin. IS60.

Describes very fully A eschna Wittei.

Giebel, (C. G.). Wirbelthier und insektenreste im bernstein. Zeitschr. gesammt. naturwiss., 20: 3I I321. 80. Halle. IS62.

Describes sixteen insects of all orders.

Giebel, C. G. Ueber eine kleine... suite von bernstein-insekten. Zeitschr. gesammt. naturw., [2], I : 87.80. Berlin. IS70.

Mentions an ant and several genera of flies in a collection received from Dr. Schreiber.

Gilbert, Ludwig Wilhelm. See Troost, G.

G[irard], M[aurice]. Les articulés fossiles. La nature, $5: 301-302.4^{\circ}$. Paris. 1877.

Brief notice of recent papers by Brongniart, including that on Protomyia Oustateti.

G[irard], M. Les perforations des bois fossiles. La nature, 6: I 1 2, figs. I-6. $4^{\circ}$. Paris. IS78.

Popular account of Brongniart's two papers on the subject with figures.

G[irard], M. Une très-ancienne araignée. $L a$ nature, 6: 144, figs. $1-4$. $4^{\circ}$. Paris. 1878.

A popular account of Attoides eresifor mis described by Brongniart.

Girard, M. Un spectre fossile. La nature, 7: 108-I I0, fig. $4^{\circ}$. Paris. I879.

Popular account of Protophasma Dumasi.

Girard, M. See also Oustalet, E.

Gistl, Johannes Nepomuk Franz Xaver. Kerfe in copal eingeschlossen. Oken, Isis, 1831, 247-248. $4^{\circ}$. Leipzig. I 831 .

Describes four new species from Brazil. Noticed in Neues jakrb. mineral., $1833,712,80$. Stuttgart. 1833 .

Goeppert, Heinrich Robert. On amber and on the organic remains found in it. Quart. journ. geol. soc. Lond., 2, i: 102-103. 80. London. 1846.

A paragraph only on the insects, p. 102, specifying the orders and numbers of insects found.
Goeppert, H. R. Die tertiäre fora von Schossnitz in Śchlesien. $4^{\circ}$. Görlitz. 1855. pp. I8, 52, pl. 26.

Six insects are figured on pl. 26 , with a brief statement concerning them on p. vii.

Goeppert, H. R. Die fossile flora der permischen formation. $4^{\circ}$. Cassel. $\mathrm{IS}_{4}-6_{5} \approx$ t. p., pp. $3^{16}$, taf. 64. Palacontogr., bal. I2. 4\%. Cassel. 1864-65.

Contains p 289 : D. Beitrage zur fauna der permisclien formation, in which he mentions and names two wings and a body of cockroaches (localities not specified) which are figured on plates 28 and 64 .

Goeppert, Heinrich Robert, und Berendt, Georg Carl. Der bernstein und die in ihm befind lichen pflanzenreste der vorwelt. fo. Berlin. I845. pp. (6), 4, 126, tab. 7. Berendt, Org. reste bernst., ba. I, abth. I.

Contains an important cliapter, pp. $4 \mathrm{r}-60$, by Dr. Berendt, on Die organischen bernstein-enschluisse im allgemeinen, treating of insects from p. $4^{6}$ on. With many details and generalizations of interest, giving the first extended review ot amber insects.

Goldberger, F. See Goldenberg, F.

Goldenberg, Friedrich. Prodrom einer naturgeschichte der fossilen insecten der kohlenformation von Saarbrücken. Sitzungsb. math.-nat. cl. akad. wiss. Wien, 9:38-39. 8o. Wien. Is'sz.

A nominal list, without description, of six new Orthoptera and Neuroptera. The author's name is accidentally given as Goldberger.

Goldenberg, F. [Brief] an Herrn v. Carnell. Zeitschr. de'utsch. geol. gesellsch., 4 : 246-248. 80. Berlin. I $\$_{52}$.

Much the same as the preceding, but with a few more details and comparisons, and without mention of specific names.

Goldenberg, F. Ueber versteinerte insectenreste im steinkohlengebirge von Saarbrücken. Amtl. ber. vers. gesellsch. deutsch. naturf., 29 : $123-126.44^{\circ}$. Wiesbaden. 1853 .

Goldenberg, F. Die fossilen insecten der kohlenformation von Saarbricken. t. p., pp. 24, pl. $4.4^{\circ}$. Cassel. IS 54. Palaeontogr., 4: 17-40, tab. 3-6. $4^{\circ}$. Cassel. 1854 .

A careful description and excellent illustration of the species mentioned in his previous papers, with as many more. The remarkable genus Dictyoneura is introduced with three species.

Goldenberg, F. Beiträge zur vorweltlichen fauna des steinkohlengebirges zu Saarbrücken. The title within is: Uebersicht der thierreste der kohlenformation von Saarbruicken. Fahresb. k. gymn. u. vorsch. Saarbr., 1867, pp. I-26. $4^{\circ}$. Saarbrücken. 1867.

The insects occupy pp. 7-20 and swell the number of Saarbrück insects to seventeen. References are made to plates, but these are not given until the same paper appears as the first heft of his Fauna saraep. foss.

Goldenberg, F. Zur kenntniss der fossilen insecten in der steinkohlen-formation. Newes jahrb. $f$. miner., 1869, pp. 158-168, pl. 3. So. Stuttgart. 1869.

Description and illustration of ten new Blattinae and two Homoptera.

Goldenberg, F. Zwei neue ostracoden und eine blattina aus der steinkohlenformation von Saarbrücken. Nitues jahrb. f. mineral., I 870 : 286-289, figs. So. Stuttgart. $1 \$ 70$.

Blattina winteriana is described and figured on pp. 288-289.

Goldenberg, F. Fauna saraepontana fossilis. Die fossilen thiere aus der steinkohlenformation von Saarbrücken. I es heft, mit zwei tafeln abbildungen. 4\%. Saarbricken. 1873. t. p., pp. 26 (2), pl. 2. $2^{\text {tes }}$ heft, mit zwei tafeln abbildungen. $4^{\circ}$. Saarbrücken. I877. pp. 4, 54, pl. 2.

The first part, with the exception of the introduction and the addition of the plates referred to in the text, is an exact reproduction of the paper published six years earlier in the report 
of the Saarbriick gymnasium, no mention being made of the author's own addifions to the carboniferous fauna since it was issued. These and others appear in the second part, where the insects occupy pp. 8-34 and pl. 1. The order Palaeodictyoptera is here instituted for the Dictyoptera (nom. praeocc.) of Dohrn. is here instituted for the Dictyoptera (nom. praeocc.) of Dohrn. all confined to Saarbrück; this brings the number of Saarbrück insects as given in the catalogue, pp. 50-51, to thirty-eight, and renders this work the most important contribution to palaeozoic entomoly A list of 76 fossif cockroaches, based on that of Heer, is given on pp. 19-2s. A cockroaches, based on that
Supplement-heft is promised.

Goldfuss, Georg August. Beiträge zur kenntniss verschiedener reptilien der vorwelt. Nova acta phys.med. acad. Leop.-Car. nat. cur., i 5, i (Verh. Leop. Car. akad. nat., 7, i.) : 61-128, pl. 7-13. $4^{\circ}$. Bonnae. I 831.

On p. 118 will be found a list of genera of insects found in the Rhenish braunkohl at Stösschen, Friesdorf, and Orsberge.

Goldsmith, E. On amber containing fossil insects. Proc. acad. nat. sc. Philad., 1879, 207-208. 8o. Philadelphia. 1879 .

Mainly a description of its physical qualities, but mentions "ants, a fly, and probably small species of Coleoptera" in a fragment picked up on the shore of Nantucket, Mass.

Goss, Herbert. Exhibition of a small collection of fossil insects obtained by Mr. J. S. Gardner from the Bournemouth leaf-beds (middle eocene). Proc. cntom. soc. Lond., 1878, p. 8 . 8o. London. 1878.

Merely mentions a few species by generic names.

Goss, H. Notes on a fossil wing of a dragon fly, from the Bornemouth leaf beds. Entom., I1 : 193$95, f_{5}$. 80. London. 1878 .

Goss, $H$. Three papers on fossil insects, and the British and foreign formations in which insect remains have been detected. No. I. The insect fauna of the recent and tertiary periods. 80. LLondon, 1878.] pp. 65. Proc. geol. assoc., 5. no. 6, pp. 282343. 80. London. 1878.

A BSTRACT: The insect fauna of the tertiary period, and the British and foreign formations in which insect-remains have been detected. Geol. mag. (n.s.), 4: 163-165. 8o. London. 1877 .

First read before the Brighton and Sussex natural history society ; afterwards before the association. This abstract, and those of the succeeding papers of this series, were published previous to the full papers. See also Bargagli, P. (in Appendix).

Goss, H. The same. No. 2. The insect fauna of the secondary or mesozoic period. 8o. [London, 1879.] pp. 37. Proc. geol. assoc., 6, no. 3, pp. II6150. 80 . London. 1879.

ABSTRACT: The insect-fauna of the secondary or mesozoic period, and the British and foreign strata in which insect remains have been detected. Geol. mag. (n. s.), 5 : 134-136. 80. London. 1878 .

Goss, H. The same. No. 3. The insect fauna of the primary or palaeozoic period. 80. [London. 1380.] pp. 32. Proc. geol. assoc., 6, no. 6. pp. 271-300. 80. London. 1880 .

ABSTRACT: The insect fauna of the primary or palaeozoic period and the British and foreign strata of that period in which insect remains have been detected. Geol. mag. (n. s.), vol. 6, pp. 230-232. 80. London. 1879 .

These three papers contain a careful review of the literature of fossil insects; each geological formation is separately treated, containing references to all the genera, and in very many cases to the species found in it, with full bibliographical references. It will be found very useful to the general student.

Goss, H. Introductory papers on fossil entomology. No. I. On the importance of an acquaintance with the subject; its bearing on the question of the evolution of insects, and the evidence it affords of the antiquity of their family types. Entom. monthl. mag., I5: I-5. 80. London. 1878 .

Goss, H. The same. No. 2. The comparative age of the existing orders of insects, and the se- quence in which they appeared on the geological horizon. Entom. monthl. mag., 15 : 52-56. 80. London. 1878 .

Goss, H. The same. No. 3. Palaeozoic time. On the insecta of the devonian period, and the animals and plants with which they were correlated. Entom. monthl. mag., 15: 124-127. 80. London. I 878 .

Goss, H. The same. No. 4. Palaeozoic time. On the insecta of the carboniferous period, and the animals and plants with which they were correlated. Entom. monthl. mag., I 5 : 169-73. So. London. I879.

Goss, H. The same. No. 5. Palaeozoic time. On the insecta of the permian period, and the animals and plants with which they were correlated. Entom. monthl. mag., I5: 226-228. 80. London. I879.

Goss, H. The same. No. 6. Mesozoic time. On the insecta of the triassic period, and the animals and plants with which they were correlated. Entom. monthl. mag., I 5 : 245-246. 80. London. I879.

Goss, H. The same. No. 7, part I. Mesozoic time. On the insecta of the jurassic period, and the animals and plants with which they were correlated. Entom. monthl. mag., I6:7-10. 80. London. 1879.

Goss, H. The same. No. 7, part 2. Mesozoic time. On the insecta of the jurassic period and the animals and plants with which they were correlated. Entom. monthl. mag., I6: 25-29. 80. London. 1879.

Goss, H. The same. No. 8. Mesozoic time. On the insecta of the cretaceous period and the animals and plants with which they were correlated. Entom. monthl. mag., 16: 58-60. 80. London. I879.

Goss, H. The same. No. 9. Cainozoic time. On the insecta of the eocene period, and the animals and plants with which they were correlated. Entom. monthl. mag., 16:124-128. 80. London. 1879.

Goss, H. The same. No. 10. Caenozoic time. On the insecta of the miocene period and the animals and plants with which they were correlated. Entom. monthl. mag., I6: I76-181. 80. London. 1880 .

Goss, H. The same. No. II. Caenozoic time. On the insecta of the post tertiary or quarternary period and the animals and plants with which they were correlated. Entom. monthl. mag., 16: 198201. 80. London. 1880.

This series of papers covers much the same ground as the preceding series of three; but the formations are followed in an ascending order, and the progress of insect life at each epoch is compared to that of other contemporary animals and plants. The lists of the other series are omitted, and the references to insects are mostly by genera.

Goss, H. The geological antiquity of insects. Twelve papers on fossil entomology, reprinted, with some alterations and additions, from vols. xv. and xvi. of the Entomologist's monthly magazine. 80. London. 1880. pp. (2), 50.

The preceding series, collected into a pamphlet.

Gravenhorst, Johann Ludwig Karl. Monographia coleopterorum micropterorum. 160. Gottingae. 1806. pp. I6, 236, (1 2), tab. 1 .

Contains, pp. 235-236, description of a single species of Oxy. porus from amber, which iu p. (3) of index is given the specific name Blumenbacbii.

Gravenhorst, J. L. K. Bericht der entomologischen section. Uebers. arb. veränd. schles. gesellsch. vaterl. cultur, $1834,88-95$. $4^{\circ}$. Breslau. I835.

On pp. 92-93 is given a list by genera of a collection of about 750 insects in amber exhibited before the entomological section of the society.

This communication has been frequently referred to Schilling, but apparently upon 110 proper grounds; his name does not appear. 
Gray, John Edward. See Buckland, W.

Grew, Nehemiah. Musaeum regalis societatis; or, a Catalogue and description of the natural and artificial rarities belonging to the Royal society and preserved at Gresham colledge; whereunto is subjoyned the comparative anatomy of stomachs and guts. fo. London. I68I. pp. (12), 3S6, (2), (2), 43. portr., pl. $3 \mathrm{I}$.

On p. 344 (misprinted 334 ), he mentions amber containing cicadas, gnats, emmets, files, and other insects. The edition of 1686 does not differ. Neither, apparently, do the editions of 1685 and 1694 which I have not seen.

Guérin-Méneville, Félix Élouard. Insectes fossiles. Dict. classique hist. nat., S : 579-581. 160. Paris. 1825 .

A review of past writers, containing nothing new excepting an attempt to indicate the genera of amber insects tigured by Sendelius.

Guérin-Méneville, F. E. See also Barthélemy-Lapommeraye, A.; Maravigna, C. ; Rondani, C.

Gutbier, August von. See Geinitz, H. B., und Gutbier, A. voll.

Haesbert, Martin Johann. De conchylio et ape petrifactis. Ephem. med. phys. acad. caes. Leop. nat. curios., dec. 3, ann. 2, pp. 48-49. 4\%. Leipzig. I695. Not seen.

Eagen, Hermann August. Die fossilen libellen Europas. Stett. entom. zeit., 9:6-13. 160. Stettin. I 848 .

A revision and brief description of the fifteen species then known.

Hagen, H. A. Ueber die fossile odonate Heterophlebia dislocata WVestwood, nebst abbildung. Stett. ent. zeit., 10:226-231, pl. I. I6o. Stettin. 1849 .

An extended description, showing that it represents a new genus of Gomphidae.

[Hagen, H. A.] Das bernsteinland. Neue preuss. frov.-blätter, 10: 75-82, I20-1 25. I60. Königsberg. IS50.

A brief statement of the amber insects is given on pp. 124-125. The species are all extinct, the genera mostly still exist.

Hagen, H. A. Ujeber die lebensweise der termiten und ihre verbreitung. Köntigsb. naturw. unterh., 2, iii : 53-75. 80. Königsberg. I 852 .

Page $7 \mathrm{r}$ treats of the fossil species in amber, and from the tertiary beds of Oeningen and Radoboj, as proving a warmer climate in ancient Europe ; of the sixty known species of white ants one third were fossil.

Hagen, H. A. Ueber die neuropteren der bernstein fauna. Verhandl. zool.-bot. ver. Wien, 4:221-232. 8. Wien. 1854 .

A systematic review of the nearly 900 specimens examined by the author. The sitzungsberichte of the same volume, pp. 76-78, contain the remarks of Brauer, comparing the results reached by Hagen with those of Loew and Göppert for Diptera and plants; and the comments of von Hauer, who indicales the places where amber is said to occur in older formations, but never with insect $\mathrm{cr}$ plant remains.

Hagen, H. A. Monographie der termiten. Linn. entom., 10: I-1 44, 270-325 (1855); I 2 : 1-342, pl. 1-3 (I 858$) ; 14: 73^{-1} 28$ (1 S60). 80. Stettin. IS 55-60.

Includes a treatment of the (14) fossil species with the others. Besides this, under the head Literatur (palaeontologie), $x: 302-$ 310 ; xii : 294-298, an analysis is given of works in which the fossil species have been previously treated. See also $\odot$.

Hagen, H. A. Catalogue of the specimens of neuropterous insects in the collection of the British museum. Part I. Termitina. I 20 . London. I858. pp. 34 .

Contains the fifteen fossil species described in the Monographie der termiten, from which indeed the whole was compiled [by Adam White? ? without the knowledge of the reputed author. None of the fossil species are recorded as in the collections of the British museum.
Hagen, H. A. Zwei libellen aus der braunkohle von sieblos. Palacontogr., 5 : $121-124$, tal. $24.4^{\circ}$. Cassel. İ̌s.

Description of Heterophlebia jucunda and Lestes vicina.

Hagen, H. A. Ascalaphus proavus aus der rheinischen braunkohle. Palaeontogr., 5 : 125-126, tab. 25. $4^{\circ}$. Cassel. IS 5 S.

Hagen, H. A. Petalura ? acutipennis aus der braunkohle von Sieblos. Palazentogr., S : 22-26, taf. 3. firs. 1-4. $4^{\circ}$. Cassel. IS 59.

Hagen, H. A. An entomological trip to Oxford. Enton. weekly intell., 10: 165-168. So. London. I86I.

Contains an account of the Sicilian amber in the Hope collection, with a notice of three species of white ants found therein.

Hagen, H. A. Insekten im sizilianischen bernstein im oxforder museum. Stett. entom. zeit., 23: 512-514. 160. Stettin. IS62.

More particularly concerncd will a notice of three species of white ants, which is much the same as that given in the preceding.

Hagen, H. A. A comparison of the fossi] insects of England and Bavaria. Entomol. annual, 1862, pp. I-IO. I6". London. I862.

Devoted almost exclusively to a comparison of the Neuroptera of the Bavarian jura and the Englishl lias-insects, by which he concludes the two faunas to be "extremely closely allied," and to be very different from the tertiary or existing forms.

Hagen, H. A. Comparison of fossil insects of England and Bavaria. Report Brit. assoc. adv. sc., 31 ; notices, I13-114. 80. London. 1862.

Dealing mostly with Odonata. The same given more fully in the Entom. antizal.

Hagen, H. A. Ueber die neuroptern aus dem lithographischen schiefer in Bayern. Palaeontogr., 10: 96-145, taf. 13-15. $4^{\circ}$. Cassel. 1862.

An introduction of nine pages, containing besides other interesting matter the comparison of the mesozoic insects of England and Bavaria given the previous year in England (see the preceding entries), is followed by a list of thirty-seven species, mostly Odonata, found at Solenhofen and Eichstätt, by five pages of a review of earlier writers, especially Germar, and by the extended description of twenty-four species, pp. $114^{-145}$.

Hagen, H. A. Neuroptern aus der braunkohle von Rott in Siebengebirge. Palaeontogr., $10: 247-$ 269, taf. 43-45. 40. Cassel. 1863 .

Extended descriptions of ten species, mostly Odonata, preceded by lists of the insects previously described from the Rhenish brown-coal.

Bagen, H. A. Phryganidarum synopsis synonymica. 80. Wien. 1864. pp. 92. Verh. zool.-bot. geseilsch. Wien, 1864, 799-890. 8o. Wien. 1864.

Includes the fossil species, twenty-eight in number, of which ten belong to Polycentropus.

Hagen, H. A. On some aberrant genera of Psocina. Ent. monthl. mag., 2 : 14S-152, 170-172. So, London. $1865-66$.

Describes two species from amber and threc from copal, besides seven recent species, being ali the ocellate species kuown.

Hagen, H. A. Psocinorum et embidinorum synopsis. 80. Wien. ז866. pp. $22 . \mathrm{Ver} / \mathrm{s}$. zool.6bot. gesellsch. Wien, IS66, 201-222. So. Wien. 1866. Includes the fossi] species, 8 Psocina, I Embidina; besides 3 Psocina from copal.

Hagen, H. A. Hemerobidarum synopsis synony. mica. Stctt. entom. zeit., IS66: 369-462. 160. Stettin1866.

Includes the fosisil species, fourteen in number.

Hagen, H. A. Die neuroptera des lithographischen schiefers in Bayern. Pars 1: Tarsophlebia, Isophlebia, Stenophlebia, Anax. $4^{\circ}$. Cassel. 1866. 
pp. 40, taf. 4. Palaeontogr., $15: 57-96$, taf. $1-4$. Cassel. $4^{\circ}$. 1866.

Extended generic and specific descriptions of eight dragonflies.

Hagen, H. A. Synopsis pseudoscorpionidum systematica. Proc. Bost. soc, nat. hist., $13: 263-272$. 8. Boston. 1870 .

A synonymic list of the known species of which fifty are recorded, ten of them (one, however, doubly recorded) fossil, all but one being from amber.

Hagen, H. A. Beiträge zur kenntniss der phryganiden. Verh. zool.bot. gesellsch. Wien, $23: 377-45^{2}$. 3o. Wien. 1873 .

Hoeninghaus's description of Phryganea mombachiana is copied on p. 379 , and the insect considered as probably belonging to the Phryganidae proper.

Hagen, H. A. On amber in North America. Proc. Bost. soc. nat. hist., I6: 296-30 1. 8o. Boston. 1874 .

Recalls Troost's paper of $182 \mathrm{t}$ on amber in Maryland and its reported inclusion of insect-nests; collects other references to American amber, and, pp. 300-301, refers to the resemblance of the fauna and flora of Prussian amber to that of the present time in North America, instancing Termopsis and Amphientomum ainong Neuroptera. See also Troost, G.

Fagen, H. A. The oldest fossil insects. Nature, $23: 483-484$. $4^{\circ}$. London. I88I.

Disputes unqualifiedly the conclusions of Scudder concerning the devonian insects.

Hagen, H. A. The devonian insects of New Brunswick. Bull. mus. comp. zoöl., 8: 275-284. 8०. Cambridge. I881.

After a "detailed comparison of a majority of the types," arrives at conclusions "radically different from the views entertained by Mr. Scudder," in his memoir on the subject.

Hagen, H. A. See also de Borre, A. P.; Cornelius, C.; Geinitz, H. B. ; Germar, E. F., und Berendt, G. C. ; Hassencamp, E.; Packard, A. S. ; Pictet-Baraban, F. J., und Hagen, H. A. ; ahd de Selys-Lougchamps, E., et Hagen, H. A.

Hagen, Karl Gottfried. Bemerkungen, die entstehung des bernsteins betreffend. Beitr. kunde Prezıss., 4:207-227. 160. Königsberg. I821.

Argues, p. 209 , from the nature of the insects entombed in it, that amber is the gum of a tree.

\section{Haidinger. See Heer, O.}

Fammerschmidt, Karl Eduard. Neue käfer in bernstein. Haidinger, Bericht. fr. naturw. Wien, I : 39. 8o. Wien. 1847.

Mere exhibition of a specimen.

Harger, Oscar. Notice of a new fossil spider from the coal measures of Illinois. Amer. journ. sc. arts, [3], 7:219-223. So. New Haven. 1874.

Extended description of A rihrolycosa antiqua with discussion of its affinities.

Hartig, Ernst. See Geinitz, H. B., Fleck, H., and Hartig, E.

Hartmann, Philipp Jacob. Succini prussici physica et civilis historia cum demonstratione ex autopsia et intimiori rerum experientia deducta. 160. Francofurti. 1677. front., pp. 291, pl. 3.

In book $\mathrm{I}$, chapt. 5 , sect. 8 , De inclusis, he mentions, p. 90 , the occurrence in amber of "aranearum non unam species; muscas majores, minores; culices, crabrones, apes, tineas, blattas, formicas, locustas ;" and in book 2, chapt. 5, sect. 8 , pp. 278-29, he endeavors to account for the occurrence of inclusions in general.

Another edition of the same date and place differs only in the plates, of which there are twenty according to Boehmer.

Hartmann, P. J. Succincta succini prussici historia et demonstratio. $4^{\circ}$. Berolini. I699. pp. (8), 48. Phil. trans., xxi : 5-40. $4^{\circ}$. London. 1699.
Sect. 3, c. iii : Animalculorum succino inclusorum accuratior demonstratio, pp. $19-21$ ( $19-22$ sep.), mentions in general terms the different sorts of insects known to be found in amber.

According to Boehmer the separate edition was accompanied by six plates, but they do not exist in the two copies I have seen; the eight preliminary pages do not appear in the Phil. trans.

A very full abstract in English, under the title An account of amber, appears in Phil. trans abr.. 2 : 473-493. $4^{\circ}$. London. 1749. The notice of the insects occurs on pp. $481-483$.

Hassencamp, Ernst. Ueber fossile insekten der Rhön. Wïrzb. nuturwiss. zeitschr., I : 78-81. 80. Würzburg. 1860 .

Contains MS. names of fossil insects by Heer, Hagen, and Heyden.

Hebenstreit, Johann Ernest. Mvsevm richterianvm continens fossilia animalia vegetabilia mar. illvstrata iconibvs \& commentariis. Accedit de gemmis scalptis antiquis liber singvlaris. fo. Lipsiae. 1743. pp. 56, 384, (16), 34, portr., pl. 17.

A few fossil insects are specified on p. 256, and a "libella" figured pl. 13 fig. 2.

Heer, Oswald. Physiognomie des fossilen Oeningen. 8o. [Winterthur, 1847], pp. 22. Verhandl. schweiz. naturf. gesellsch., 31 : 159-180. 80. Winterthur. 1847 .

A general report on the insects will be found on pp. $167^{-174}$. Separate copy not seen.

Feer, O. Ueber die fossile insekten-fauna der tertiär-gebilde von Oeningen und Radoboj und die pflanzen aus gleicher formation an der hohen Rhone, aus einem briefe an Professor Bronn. Neues jahrb. f. mineral., 1847: 161-167. So. Stuttgart. 1847 .

A catalogue of the beetles described in the first part of the following work, with brief remarks on the general aspect of the fauna.

Translation. On the fossil insects of the tertiary formation of Oeningen and Radoboj. Quart. journ. geol. soc. Lond., 3, it: 60 . 80. London. 1847. Catalogue and concluding remarks omitted.

Heer, O. Die insektenfauna der tertiärgebilde von Oeningen und von Radoboj in Croatien. Erster theil : Käfer. 40. Leipzig. 1847. tp. pp. 2, 229, I, pl. 8. Neue denkschr. allg. schweiz. gesellsch. f. wissensch., 8. $4^{\circ}$. Neuchâtel. I 847 .

Heer, O. The same. Zweiter theil : Heuschrecken, florfliegen, aderflügler, schmetterlinge und fliegen. Mit 17 lithographirten tafeln. $4^{\circ}$. Leipzig. 1849. pp. 264,5 , pl. 17. Ibid., 11. $4^{\circ}$. Zürich. 1850.

Heer, O. The same. Dritter theil: Rhynchoten. Mit 15 lithographirten tafeln. $4^{\circ}$. Leipzig. 1853 . pp. 4,138 , pl. 15 . Ibid. 13 . $4^{\mathrm{o}}$. Zürich. 1853 .

This classical work is the most important ever published upon fossil insects, and may be called the first serious attempt at the classification of the tertiary species. M Most of the material came from Oeningen and Radoboj, but it included all the author could examine from Aix and other localities. 462 species are described and figured, divided as follows: 1 ig Coleoptera, 39 Gymnognatha, 3 Neuroptera, 80 Hymenoptera, 9 Lepidoptera, 8o Diptera, and r 33 Hemiptera. There are very few general observations, but attention should be called to an important excursus on the arrangement of the veins in the wings of insects and the elytra of Coleoptera, in the first part, pp. 76-95.

Reviewed by T. R. J(ones) in Quart. journ. geol. soc. Lond., 9 ii. 33. $8^{\circ}$. London. 1853 .

Diagnoses of the species described in the third part appeared, without title, in the Bericht österr. litt. zool. bot. pakont., 1850-53: 199-203. 80 Wien. 1855 .

Heer, O. Ueber die vorweltlichen käfer von Oeningen. Mittheil. naturf. gesellsch. Zürich, I, i : I7-I8. 80. Zürich. I847.

A brief general statement of the peculiarities of the beetlefauna of Oeningen.

Heer, O. Ueber vorweltliche florfliegen. Mittheil. naturf. gesellsch. Zürich, I, ii : 52-54. 80. Zürich. 1848 .

A brief notice of the fossil dragon-flies of Oeningen and Radoboj. 
Heer, O. Ueber fossile ameisen. Mittheil. naturf. gesellsch. Zürich, 1, ii : 167-174. 8o. Zürich. 1848 .

The fossil ants of Oeningen and Radoboj are winged and either $\delta$ or \&, neuters being rarely preserved; three fourths are females. The individuals are very abundant and are preserved in large assemblages, and many species in close contignity most of them are Formicidae, and they form the best data for comparison of the Oeningen and Radoboj faunas.

Translation. On fossil ants. Quart. journ. geol. soc. Lond., 6, ii.: 6I-65. 80. London. 1850.

Translated by T. R. J(ones).

Heer, O. Fauna von Radoboj. Aus einem briefe [an Herrn bergrath Haidinger.] Haidinger, $\mathrm{Be}$ richte, $5: 86-87$. 80. IVien. I849.

Notice of the more remarkable insects belonging to the Vienna museum, and which are described in his great work, followed by brief remarks on the Radoboj insect fauna as a whole; and by comments of Haidinger.

Heer, O. Brief von O. Heer. Haidinger, $B e$ richte, 5: 107. 80. Wien. 1849 .

Notice of some peculiarities in the insect fauna of Radoboj in a letter to Unger.

Heer, $O$. Nachricht über die ersten ergebnisse einer durchsicht der reichen suite fossiler insecten, die von Herrn custos Freyer in Radoboj gesammelt ... worden waren. Haidinger, Berichte, 6:5-7. 80. Wien. I849.

Cursory report of his first examination of a considerable collection of Radoboj insects, three fifths of which were found to be ants.

Heer, O. Die Morlot'sche sammlung von fossilen insecten aus Radoboj. Haidinger, Berichte, 6: 132134. 80. Wien. I849.

A similar report to the last in the same volume; the ants bear the same proportion as before and make the tertiary European species equal in number to the living.

Heer, O. Zur geschichte der insekten. Vortrag. 80. N. P., N. D. pp. 20. Verhandl. schweiz. gesellsch. gesammt. natumw., 34:78-97. 80. Frauenteld. I 849. Neues jahrb. $f$. mineral., 1850, 17-33. 80. Stuttgart. I 850 .

A popular address, presenting a sketch of the sequence of insect life and the development of special groups, with general considerations based on a broad survey of the subject; by far the best account of the knowledge of that time. An abstract is given in Haidinger's Berichte, $6: 135^{-136}$. 80. Wien. 1849 .

Translation. On the history of insects. Quart. journ. geol. soc. Lond., 6, ii : 68-76. 80. London. 1850 .

Translation by T. R. J(ones).

Heer, O. I. [Zwei] geologische vorträge gehalten im März 1852 von Osivald Heer und A. Escher von der Linth. I. Die lias-insel des Aargau's. Entitled on cover: Ueber die lias-insel im Aargau. 2. Ueber die gegend von Zürich in der letzten periode der vorwelt, mit einer blockkarte der Schweiz. $4^{\circ}$. Zürich. [1852].. pp. 28 , pl. 2 .

Heer's portion, pp. $1-15$, pl. $x$, is largely devoted to insects, the greater part of which are wood-boring coleoptera, and indicate a warm tropical climate. Twenty-lwo species are described and figured, of which nineteen are beeties.

Heer, O. Beschreibung der angeführten pflanzen und insekten. $4^{\circ}$. N. P., N. D. pp. 2 I, taf. (3). Also in Escher v. d. Linth (A.) Geologische bemerkungen über das nördliche Voralberg und einige angrenzenden gegenden. pp. I I 5-1 35, taf. 6-8. Neue denkschr. allg. schweiz. gesellsch. gesammt. naturw. I3. 40. Zürich. I853.

B. Insekten, pp. 18-21 (133-35), taf. 7. Describes two beetles from the trias of Vadutz.
Heer, O. Ueber die rhynchoten der tertiärzeit. 8o. Zürich. 1853. pp. 29 Mitth. naturf. gesellsch. Zürich, 3: 17 I-197. So. Zürich. 1853.

General account of the relations of the Rhynchota of Oeningen, Radoboj, and Aix to existing fannas. followed by a list of the species described in the third part of his Tertiary ínsects. They agree better with the insects of the Southern zone than with those of Switzerland, and the Capsini and Riparii characteristic of temperate regions are wholly absent.

Eeer, O. Flora tertiaria Helvetiæ. Die tertiäre flora der Schweiz. 3 v. $4^{\circ}$. Winterthur. $1854-59$. Bd. I, 1854-55, t. p., pp. 6, I 17, pl. 50;-bd. 2, 1850 , pp. 4, I 10, pl. 51-100;-bd. 3, I859, pp. 6, I-200, t. p., pp. $201-378$, pl. I01-1 56, map.

Bd. $\mathrm{t}$ refers to Oeningen insects on pp. 10- 11 . The latter half of bd. 3 was republished in 1860 under the title: Untersuchungen ïber das klima n. s. w. (q. v.). See also the next entry, and Die klimatischen verhaltnisse, u. s. w. 1860 .

Heer, O. Introduction à la flore tertiaire de la Suisse traduite par Charles Th. Gaudin. Arch. sc. phys. nat., 26: 293-314. So. Genève. 1854 .

A translation of the preliminary matter in the first volume of the preceding; running references to the insects of the period occur here and there, especially on pp. $310,3 \mathrm{Ir}$.

Heer, O. Ueber die fossilen insekten von Aix in der Provence. Vierteljihrsschr. naturf. gesellsch. Zürich, I, i: 1-40, taf. 1-2. 80. Zürich. I856.

The first important paper on Aix insects, cataloguing and describing sixty species of all orders, preceded by remarks on the general characteristics of the fauna, which is considered to have marked Mediterranean features.

Heer, O. Ueber die fossilen pflanzen von St. Jorge in Madeira. Neue denkschr. allg. schweiz. gesellsch. gesammt. naturw., 15 (art. 2). $4^{\circ}$. Zürich. 1857. pp. 40 , pl. 3.

Laparocerus Wollastoni described in a note on p. 14 , and figured pl. 2, fig. 34 .

Heer, O. [Sur l'étude de la flore tertiaire.] Lettre à $\mathrm{Sir} C h$. Lyell. Bull. séunces soc. vaud. sc. nat., 5: 145-1 51. pl. 80. Lausanne. $185^{8}$.

American types among Oeningen insects, p. $\mathbf{4}_{4} 8$, and relation of the Oeningen insects and plants, p. 150.

Heer, O. Les charbons feuilletés de Durnten et d'Utznach; discours de M. le professeur O. Heer traduit par M. Charles-Th. Gaudin. Arch. sc. phys. nat. (nouv. pér.), 2 : 305-339. 80. Genève. 1858.

In a note, p. 322, mentions the occurrence of species of Donacia and Hylobius in the Durnten clays. This appears to be the only publication of the address.

Heer, O. Ueber die insectenfauna von Radoboj. Amtl. ber. vers. deutsch. naturf., $3^{2}:$ 118-126. $4^{\circ}$. Wien. I858.

A review of the subject based on the insects described in his general work. The author finds a commingliug of European and Indian forms; perfect dragon-flies but no larvae, showing the deposit to be marine; the occurrence of plants in the same beds, with which the insects have special relations; a closer connection of Radoboj with Aix than with Oeningen.

Heer, O. Ueber die fossilen calosomen. $4^{\circ}$. [Zürich, I860.] pp. Io. pl.

Published in the Programm of the Polytechnicum of Zürich. Seven species are described and figured from Locle and Oeningen, preceded by general remarks on fossil and recent Carabidae.

Heer, O. Die klimatischen verhältnisse des tertiärlands aus O. Heer's tertiärflora der Schweiz, bd. 3. s. 327-350 im auszuge mitgetheilt. Zeitschr. gesammt. naturw., I 5 : I-42. 80. Berlin. 1860.

Insects are treated of on pp. 11,12 .

Heer, O. Untersuchungen über das klima und die vegetationsverhältnisse des tertiärlandes. Mit profilen und einem kärtchen Europa's. Separatabdruck aus dem dritten band der Tertiären flora 
der Schweiz. $4^{\circ}$. Winterthur. I860. t. p., pp. 170, pl. (clvi), karte.

Contains a couple of paragraphs. pp. 134-135 (334-335 of original) upon the tertiary insects and the testimony they bear to the tropical and American nature of the tume in which they lived. Another paragraph on pp. 60-61 (260-261) shows how the condition of preservation of insects indicates the season of their entombment.

Translation. Recherches sur le climat et la végétation du pays tertiaire. Traduction de Charles Th. Gaudin. Avec des profils et une carte de l'Europe. $4^{\circ}$. Winterthur, Genève et Paris 186r. pp. 220. 22, pl. 1, carte.

The paragraphs on pp. $134^{-135}$ of the original are very much expanded on pp. 196-205 of this translation, and include full tables of the families of insecls and their numerical representation in the different European deposits of tertiary time. Besides this, M. Gaston de Saporta in his Examen des flores tertiaires de Prozence, pp. 133-171, gives a paragraph, pp. 152-153, concerning the insects of Aix. The semaining paragraph referred to above appears unchanged on p. $6 \mathrm{r}$.

Heer, O. On the fossil flora of Bovey Tracey. Phil. trans. I 52 : 1039-1086, pl. 55-7 I. $4^{0}$. London. 1862.

Insects from Bovey, p. 1082, pl. 68.

Heer, O. Beiträge zur insektenfauna Oeningens. Coleoptera - geodephagen, hydrocanthariden, gyriniden, brachelytren, clavicornen, lamellicornen und buprestiden. Natuurk. verhand. holl. maatsch. wetensch. Haarl. [2], I6: I-90, taf. I-7. 40. Haarlem. I862.

Describes and figures no species, nearly all of them new. In an introduction of five pages, some general results of the study of Oeningen Coleoptera are tabulated, the most interesting of which appear to be that the fauna is more European in character than the flora and less rich in American forms; and that many species are related to those which now enjoy a wide distribution.

Heer, O. Ueber die fossilen kakerlaken. Vierteljahrsschr. nat. gesellsch. Zürich, 9, jv.: 273-302, pl. 8o. Zürich. I $\$ 64$.

The first attempt to classify the cockroaches of the carboniferous period, followed by a catalogue of the fifty-four known fossil species from all formations, and descriptions and figures of ten new species.

Heer, O. Die urwelt der Schweiz. Mit sieben landschaftlichen bildern, elf tafeln, einer geologischen uebersichtskarte der Schweiz und zahlreichen in den text eingedruckten abbildungen. So. Zürich. 1865 . pp. 29, 622, pl. 7, (4), map, 368 figs. in text.

Contains a general account of the lias insects, pp. $81-96, p]$. 7-8; of those of Oeningen, pp. 355-397, figs. 215-323; and of the pleistocene of Utznach, etc., pp. 500-503, figs. 352-359. Many forms are described and figured for the first time.

Translation. Le monde primitif de la Suisse. Traduit de l'allemand par Isaac Demole.

80. Genève et Bale, I872, pp. I6, 80I, pl. II, carte, 368 figs. in text.

The insects occupy p. 22, fig. $16 \mathrm{c}$ (carboniferous); pp. 99-117, pl. 7-8 (lias); pp. 436-486, tigs. $215-323$ (Oeningen); and pp. 613-616. figs. 352-359 (Utznach, etc.). Some few additions are made by the author.

Translation. The primitive world of Sivitzer. land, with 560 illustrations. By Professor Heer. Edited by James Heywood. 2 vols. 8\%. London. 1876. 1, pp. I6, 393, map, pl. 6; -2, pp. 8, 324, pl. $\mathrm{xi}$. and 4 scattered plates.

The insects occupy I : p. 20 , fig. I 6 c (carboniferous); pp. $8 \mathrm{I}-95$, pl. $7^{-8}$ (lias); II : pp $9-56$, figs. 2 I $1-323$ (Oeningen); and pp. 167-170, figs. 352-353 (Utznach, etc.).

Heer, O. Die urwelt der Schweiz. Zweite umgearbeitete und vermehrte auflage. 8o. Zürich. IS79. pp. I9, 7I3, taf. 8 (4), map, 417 figs. in text.

The insects are here somewhat enlarged over the previous editions, occupying pp. 24-25, fig. 34 (carboniferous); pp. 91-105, pl. 7-8 (lias); pp. $380-422$, figs. $250-365$ (Oeningen); and pp. 530-533, figs. 395-402 (Utznach, etc.).
Heer, O. Fossile hymenopteren aus Oeningen und Radoboj. $4^{\circ}$. [N. P.] [N. D.] pp. 42, pl. 3. Nene denkschr. allgem. schweiz. gesellsch. gesammt. natumi., 22. $4^{\circ}$. Zürich. $1 \$ 67$.

Catalogues and describes sixty-nine species. In an appendix, p. 42 , notice is taken of Mayr's criticism of his former treatment of the fossil ants.

Heer, O. Flora fossilis arctica. Die fossile flora der polarländer. $6 \mathrm{v}, 4^{\circ}$. Zürich. I 868-So. Bd. I, 1868, pp. 7, I92, map, pl. 50 ; - bd. (2), I $869-7$ I (no t. p.), pp. 7 ; (i.) pp. $445-4 S S$, pl. 39-56; (ii.) pp. 4 I, pl. Io; (iii.) pp. 98, pl. I6; (iv.) pp. 5I, pl. I 5 ; bd. 3 , 1875 , t. p., pp. 6 ; i. pp. 11 , pl. 6 ; ii. pp. 138 , (2), pl. 38 ; iii. pp. 29 , pl. 5 ; iv. pp. 24 ; - bd. 4 , 1877 ; i. pp. 7 , 141 , pl. 32 ; ii. t. p., pp. 122 , pl. 31 ; iii. pp. 15, pl. 2 ; - bd. 5,1878 ; i. pp. 4 , 33, front., pl. 9 ; ii. t. p., pp. 58 , pl. 15 ; iii. t. p., pp. 6 1, pl. 15 ; (iv.) pp. I I, pl. 4 ; (v.) pp. 6, pl. I;-bd. 6. i, ISSO. pp. (4), t. p., $34,17,38$, pl. 9, 6, 3 .

The contents will be found under the special papers.

Heer, O. Flora fossilis arctica. Die fossile flora der polarländer enthaltend die in Nordgrönland auf der Melville-insel, im Banksland, am Mackenzie, in Island und in Spitzbergen entdeckten fossilen pflanzen. Mit einem anhang über versteinerte hölzer der arctischen zone von Dr. C. Cramer. $4^{\circ}$. Zürich. 1868. pp. 7, 192, map, pl. 50.

Contains: Fossile insecren von Nordgrönland, pp. 120-130, pl. 19, 50; four species described. Miocene flora von Island: Gliederthiere, $\mathrm{pp} .154^{-1} 55, \mathrm{pl} .27$ : one beetle described.

Forms vol. 1 of Heer's Flora fossilis arctica.

Heer, O. Flora fossilis alaskana. Fossile flora von Alaska. $4^{\circ}$. Stockholm. I869. pp. 4I, pl. 10. Kongl. svenska vetensk.-akad. handl., 8, iv. $4^{\circ}$. Stockholm. 1869 .

Describes Chrysomelites alaskanus, p. 39, pl. ro.

Forms vol. 2, no. ii. of Heer's Flora fossilis arctica.

Heer, O. Die miocene flora von Spitzbergen. Vorgetragen ... bei der versammlung der schweizerischen naturforschenden gesellschaft, den $23 \mathrm{Au}$ gust, I 869, in Solothurn. 80. Solothurn [n.d.]. pp. 15. Verhandl. Schweiz. naturf. gesellsch., 53: 156I69. 80. Solothurn. I870.

Zeitschr. gesammt. naturw. (2), 1 : 318-324. So. Berlin. 1870.

Notices insects briefly at p. 12 (Vorkandl. 165, Zeitschr. 323).

Translation. La flore miocène du Spitzberg. Ann. sc. nat. (5) bot., 12 : 302-311. 80. Paris. 1869.

Insects on pp. 308-309.

Heer, O. Preliminary report on the fossil plants collected by Mr. Whymper in North Greenland in 1867. Rep. Brit. assoc. adv. sc., 39:8-10. 80. London. I870.

Two insects mentioned on p. ro.

Heer, O. Contributions to the fossil flora of North Greenland, being a description of the plants collected by Mr. Edward Whymper during the summer of I 867. Phil. trans., I $59: 445-488$, pl. 39-56. $4^{\circ}$. London. I870.

Contains description, pp. 484-485, and figures, pl. 44, fig. 9, and $\mathrm{pl}$. 56 , fig. 14 of two insects, under the heading: Animals from Atanekerdluk. A. Insecta.

The paper forms vol. $z, n^{\circ}$. i. of Heer's Flora fossilis arctica.

Heer, O. Die miocene flora und fauna Spitzbergens. Mit einem anhang über die diluvialen ablagerungen Spitzbergens. $4^{\circ}$. Stockholm. I870. pp. 98, taf. I6. Kongl. svenska vetensk.-akad. handl., 8, vii. $4^{\circ}$. Stockholm. I870.

Zweiter abschnitt: Beschreibung der miocenen thiere Spitzbergens. I. Insekten, pp. $73 \rightarrow 8$, pl. 16; contains descriptions of twenty-three insects. of which twenty are Coleoptera.

Foms vol. 2, no. iii. of Heer's Flora fossilis arctica. 
Heer, O. Ueber die braunkohlen-flora des Zsilythales in Siebenbürgen. 8o. Pest. 1872. pp. 24 , pl. 6. Mitth. jahrb. ung. geol. anst., Ld. 2, lief. i. So. Pest. IS72.

Mentions the discovery of fossil insects in the tertiary beds of Tállya.

Heer, O. Die kreide-flora der arctischen zone, gegründet auf die von den schwedischen expeditionen von 1870 und $\mathrm{IS}_{72}$ in Grönland und Spitzbergen gesammelten pflanzen. $4^{\circ}$. Stockholm. I874. pp. I 38, pl. 38. Kongl. sienska vetensk.-akad. handl., I 2, vi.

Insekten der komeschichten, pp. 91-92, pl. 17: describes two Coleoptera. Myriopoden, pp. 120-121, pl 33 ; describes Julopsis cretacea.

Forms vol. 3, no. ii. of Heer's Flora fossilis arctica.

Heer, O. Nachträge zur miocenen flora Grönlands, enthaltend die von der schwedischen expedition in sommer 1870 gesammelten miocenen pflanzen. $4^{\circ}$. Stockholm. 1874. pp. 29, pl. 5. Kongl. svenska i'etensk.-akad. handl., I 3, ii.

Insekten, p. 25, pl. 5 ; describes two species of Cistelites.

Forms vol. 3 , no. iii. of Heer's Flora fossilis arctica.

Heer, O. Beiträge zur jura flora Ostsibiriens und des Anurlandes. t. p., pp. 122, pl. 31. Mém. acad. imp.sc.St. Pétersb., (7), 22, xii. $4^{\circ}$. St. Pétersbourg. I876.

Elaterites sibiricus is described on p. 41 .

Forms vol. 4, no. ii. of Heer's Flor a fossitis arctica.

Heer, O. Flora fossilis helvetica. Die vorweltliche flora der Schweiz. $4^{\circ}$. Zürich [1876-] I877. t.p., pp. 6, I82, pl. 70 .

Describes, p. 76, and figures, pl. 27, a single beetle from the keuper of Rütihard, canton Basel, and a neuropteron on p. 77, pl. 29, from the trias of Mythen, canton Schwyz.

Heer, O. Notes on fossil plants discovered in Grinnell Land by Captain H. W. Feilden, naturalist of the English north polar expedition. Quart. journ. geol. soc. Lond., 34: 66-72. 80. London. is 88 .

Mentions, p. 69, the occurrence of a single elytron of a beetle with the plants.

Heer, O. Ueber einige insektenreste aus der raetischen formation Schonens. Förhandl. geol. foren. Stockh., 4, vii : 192-197, taf. I3. 80. Stockholm. I878.

Description and figures of eight Coleoptera.

Heer, O. Die miocene flora des Grinnell-Landes gegründet auf die von Cap. H. W. Feilden und Dr. E. Moss in der nähe des Kap Murchison gesammelten fossilen pflanzen. $4^{\circ}$. Zürich. 1878 . pp. $3^{8}$, front., pl. 9.

Describes and figures a single beetle.

Forms vol. 5, no. i. of Heer's Flora fossilis arctica.

Heer, O. Primitiae florae fossilis sachalinensis. Miocene flora der insel Sachalin. t. p., pp. 6I, pl. I 5. Mém. acad. imp. sc. St. Pétersb., 25, vii. $4^{\circ}$. St. Pétersbourg. 1878 .

Describes a single beetle.

Forms vol. 5, no. iii. of Heer's Flora fossilis arctica.

Heer, O. See also de.Borre, P., Hassencamp, E., Loew, H., and Mayr, G. L.

Helwing, Georg Andreas. Lithographia angerburgica, sive lapidum et fossilium, in districtu angerburgensi \& ejus vicinia, ad trium vel quatuor milliarium spatium, in montibus, agris, arenofodinis $\&$ in primis circa lacuum littora \& fluviorum ripas, collectorum brevis \& succincta consideratio additis rariorum aliquot figuris aeri incisis, cum praefatione autoris \& indicibus necessariis. $4^{\circ}$. Regimonti. I717. pp. (I 4), 96 (I 3 ), front. pl. I I.

Ibid. Pars II. In qua de lapidibvs figvratis ad triplex regnvm minerale, vegetabile et animale redactis aliisqve fossilibvs in districtv angerbvrgensi ejvsque vicinia noviter detectis, et in specie de origine lapidvm literas exprimentivm, occasione lapidis cvjvsdam resaviensis, literas latinas L. V. R. repraesentantis, svccincte disseritvr; additis iconibvs rariorum. 4\%. Lipsiae. 1720. pp. I32, pl. 6.

On p. 78 is given a short notice of insects (formicae, blattae, tipulae, millipedes aliaque insecta) in amber.

Hensche, A. Ueber den bestand und die neueren erwerbungen der bernsteinsammlung. Schrift. phys.öron. gesellsch. Königsb., 5, sitzungsb., I4-15. $4^{\circ}$. Königsberg. I864.

History of the growth and present extent of the collection, rich in insect inclosures.

Hensche, A. Bericht über die bernsteinsamm. lung der königl. physikalisch-ölionomischen gesellschaft. Schrift. phys.ökon. gesellsch. Königsb., 6: 210-21 5. $4^{\circ}$. Königsberg. 1S65.

Contains 8853 specimens, with insect inclosures, of which over 6000 are Diptera; tables of the different groups are given on pp. 211-213.

Henslow, John Stevens. Supplementary observations to Dr. Berger's account of the Isle of Man. Trans. geol. soc. Lond., v : 482-505. $4^{\circ}$. London. I 821 .

Under the head of diluvial deposits, he refers, p. 501, to a bed of peat in the parish of Kirk Balaff, " containing a vast number of the exuviae of beetles, bees and their nests, crushed together with seed vessels, rolten, but having their external coating well preserved. . . In general the hard wings are the only parts of the beetles which are preserved, and these are in appearance as fresh as on a living insect. Dr. Leach was enabled to identify a few with species at present existing in England."

Hepp, Philipp. Ueber die bei Dürkheim aufge. fundene versteinerte phryganeen gehäuse. Fihresb. Pollich., 2 : 19-23. 80. Neustadt a. d. Haardt I844. An abstract is given in Oken's 1 sis for 1846 . p. 70 .

Ferold, Johann Moritz David. See Koehler, F. Hessel, Johann Friedrich Christian. See Koehler, F.

von Heyden, Carl. Chrysobothris veterana und Blabera avita, zwei fossile insekten von Solenhofen. Palaeontogr., I : 99-101, pl. 12, fig. 4-5. 4\%. Cassel. I 847 .

von Heyden, C. Reste von insekten aus der braunkohle von Salzhausen und Westerburg. Palaeontogr., 4 : 198-201, pl. 37-38. 40. Cassel. 1856.

Divided into: Dicerca Taschei Heyden aus der braunkohie von Salzhausen, pp. 198-199, pl. 37, figs. 1-4. - Gänge von insekten-larven in hölzern der braunkohle von Salzhausen, pp. 199200, pl. 38 ; borings of an Anobium, a Prionus, and a buprestid. Fliegen aus der braunkohle der grube Wilhelmsfund bei Westerburg in herzogthum Nassau, pp. 200-201, pl. 37, figs. 6-8; Three species described.

von Heyden, C. Fossile insekten aus der braun. kohle von Sieblos. Palaeontogr., $5: 11$ 5-120, pl. 23. 40. Cassel. $185^{\circ}$.

Description of ten species, mostly beetles.

von Heyden, C. Fossile insekten aus der rheinischen braunkohle. Palaeontogr., 8: I-15, pl. I, 2, figs. I-1 3. 40. Cassel. I 859 .

Description of twenty-five insects of various orders:

von Heyden, C. Fossile insekten aus der braunkohle von Sięblos (nachtrag). Palaeontogr., 8: I 5-1 7, pl. 3, figs. 7-9. 4\%. Cassel. 1859.

Description of a beetle and two Hemiptera.

von Heyden, C. Nachricht von fossilen gallen auf blättern aus den braunkohlengruben von Salzhausen. Ber. oberhess. gesellsch. nat. heilk., 8: 63 . 80. Giessen. I860.

Probably the gall of a Phytoptus, on Salix. 
von Heyden, C. Gliederthiere aus der braunkohle des Niederrhein's, der Wetterau und der Röhn. Pulaeontogr., Io: 62-S2, pl. 10. $4^{\circ}$. Cassel. 1 \$ 62 .

Description of a crustacean, two arachnids, and thirty-two hexapods of various orders.

von Heyden, C. See also Hassencamp, E. von Heyden, Carl und Lucas. Bibioniden aus der rheinischen braunkohie von Rott. Palueontogr., It: 19-30, pl. 8, 9, figs. 1-12. 40. (Cassel.) 1865 .

Description of twenty-three species, mostly Protomyia, and remarks on three or four others.

von Heyden, C. und L. Fossile insekten aus der braunkohle von Salzhausen. Palaeontogr., 14 : 31-35, pl. 9, figs. 13-22. 40. (Cassel.) I 865 .

Description of twelve insects, mostly Coleoptera, and remarks on three others.

von Heyden, C. und L. Käfer und polypen aus der braunkohle des Siebengebirges. Palaeontogr., 15 : 1 31-159 [käfer, 131-157], pl. 22-24. 40. Cassel. 1366.

With the following, reprinted under the title: Käfer und polypen aus der braunkohle des Siebengebirges. - Dipteren-larve aus dem tertiär-thon von Nieder-Flörsheim in Rhein-Hessen, mit 3 tafel abbildungen. Besonderer abdruck aus den Palaeontographicis, $x v . \quad 4^{\circ}$. Cassel. 1366. pp. $1-29$, pl. $1-3$.

Describes sixty beetles.

von Heyden, C. und I. Dipteren-larve aus dem tertiär-thon von Nieder-Flörsheim in Rhein-Hessen. Palizeontogr., 15: 157, pl. 23, fig. 22. Cassel. $4^{\circ}$. 1866.

See the preceding entry.

von Heyden, Lucas. Fossile dipteren aus der braunkohle von Rott im Siebengebirge. $4^{\circ}$. Cassel. 1870. t. p., pp. 2, 30, pl. I-2. Palaeontogr., 17: 237-266, pl. 44-45. 40. Cassel. I870.

Describes forty-one species of seventeen genera, besides seven larvae of two different genera. In an appendix, pp. 265-266, a few details are given of other insects, and the collections in which they are found.

Hislop, Stephen. On the age of the fossiliferous thin-bedded sandstone and coal of the province of Nágpur, India. Quart. journ. grol. soc. Lond., 17, i : $346-354$. 8o. London. $186 \mathrm{t}$.

Refers to the discovery of Blattariae and Coleoptera at Kotá, probably liassic.

Hislop, S. Supplemental note on the plantbearing sandstones of central India. Quart. journ. geol. soc. Lond., i8, i : $36.88^{\circ}$. London. 1862.

Discovery of more insects at Kotá.

Hitchcock, Charles Henry. See Hitchcock, E. Hitcheock, Edward. Ichnology of New England. A report on the sandstone of the Connecticut valley, especially its fossil footmarks, made to the government of the commonwealth of Massachusetts. $4^{\circ}$. Boston. 1858. pp. 12, 220, pl. 60 .

Refers to prints, supposed to be those of insects, on pp. 147$160,165-166,188-189$, and mentions an insect larva, pp. 7-8. The figures of these are distributed on plates $7,24,27,28,29,30$, 31, 42.

Hitchcock, E. Supplement to the Ichnology of New England, a report to the government of Massachusetts in 1863. $4^{\circ}$. Boston. 1865. pp. 10, 96, pl. 20.

Appendix B. Descriptive catalogue of the specimens in the Hitclicock ichnological cabinet of Amberst college : prepared by C. H. Hitchcock. pp. 41-83; tracks of insects, pp. 13-17; tracks of myriapods, $\mathrm{pp}$. $17^{-18}$.

Hitchcock, E. See also Dana, J. D.

Hoeninghaus, Friedrich Wilhelm. Phryganea mombachiana. 4\%. Crefeld. I844. I engr. p. with illustr.
Text in German, accompanied by a French translation of the text (with no heading), I p. $8^{\circ}$. See also Hagen, H. A., and Michelin, $\mathrm{H}$.

Holl, Friedrich. Handbuch der petrefactenkunde; mit einer einleitung über die vorwelt der organischen wesen auf der erde, von Dr. Ludwig Chonlaut. I es bändchen. 160. Dresden. I829. pp. 8, 489. Allg. taschenbibl. der naturwiss., $9^{\text {ter }}$ theil.

A brief account of fossil insects under the heading Entomolithen, pp. $13^{8-141}$, with description of two species of Formica from amber.

Holl, F. Handbuch der petrefactenkunde; eine beschreibung aller bis jetzt bekannten versteinerungen aus dem thier-und pflanzenreiche zur leichten erkennung und auffindung der fossilien; mit einer einleitung über die vorwelt der organischen wesen auf der erde, von Dr. Ludwig Choulant. Neue ansgabe. 16\%. Quedlinburg und Leipzig. 1843. Pp. 8, 489. Published in four parts with continuous pagination, the t. p. of pt. $2-4$ not included.

Appears to differ from the preceding only in title.

Hope, Frederic William. Observations on succinic insects. Trans. ent. soc. Lond., I : 133-147; 2 : $46-57$, pl. 7 . 80. London. $1836-37$.

General remarks on the insects found in amber and gum animé, followed by a list of insects hitherto noticed by the author or known to Berendt. The species are all claimed as distinct from the recent, and to be tropical in their affinities.

Hope, F. W. Description de quelques insectes non décrits trouvés dans la résine animée. Mag. de zool., [2] 4 : ins., pl. 87-89. 80. Paris. 1842.

Three coleoptera are described and figured in detail.

Hope, F. IV. Observations on the fossil insects of Aix in Provence, with descriptions and figures of three species. Trans. ent. soc. Lond., 4: 250-255, pl. 19, figs. 1-3. 80. London. 1847.

Contains a list of genera occurring at Aix and " descriptions of three fossil species of insects" (Balaninus, Rhynchaenus, Corizus) from same localily.

Hope, F. W. Descrizione di alcune specie d' insetti fossili pel Rev. G F. Hope; memoria presentata all' Accademia degli aspiranti naturalisti, in Dicembre 1847 , ed inserita negli annali della stessa [with notes by A. Costa]. 80. (Napoli) N. D. pp. 7, pl. Ann. acc. aspir. nat. Najoli, 1847. pp. 一, tav. 10. 80. Napoli.

Five species described and figured.

Horn, George Henry. Notes on some coleopterous remains from the bone cave at Port Kennedy, Pennsylvania. Trans. Amer. ent. soc., 5 : 24I-245. 8o. Philadelphia. 1876 .

Collected, without change of pagination, with other papers under the tille: Miscellaneous papers on American coleoptera. Eleven species are described.

Hueber, Georgius Ludovicus. See Beringer, J. D. A.

Hünefeld, L. Ueber bernstein-insecten. Oken, Isis, 1831 : " 2000 " [ 1100$] .44^{\circ}$. Leipzig. I 831 .

A list of insects is given by Burmeister.

Humbert, Alois. See Scudder, S. H.

John, Johann Friedrich. Naturgeschichte des succins, oder des sogenannten bernsteins; nebst theorie der bildung aller fossilen, bituminösen, inflammabilien des organischen reichs und den analysen derselben. 2 th. 160. Köln. I816. Ier th.

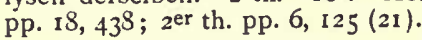

A list of insects found in amber, arranged by genera, will be found in I. pp. 221-223; and in I. pp. 169-176, a bibliography of amber literature. 
Joly, Nicolas. Incontestablement, le Prosopistoma de Latreille est un éphémérien. Mém. acad. sc. Toulouse, [8], 2 : 188-189. 80. Toulouse. 1880.

At the end of his paper, p. 189 , he refers a secondary fossil figured by Brodie to this genus.

Jones, Thomas Rupert. Fossil insects. Geol. mag., $7: 348$. 80. London. 1870.

Correction of geological horizon of certain insects described by Westwood.

Jones, T. R. See also Heer, O.; Mantell, G. A. Jordan, Hermann und von Meyer, Hermann. Ueber die crustaceen der steinkohlenformation von Saarbrïcken. Palaeontogr., 4 : I-15, pl. I-2. $4^{\circ}$. Cassel. 1854 .

Describes, among other things, Adelophthalmus (Eurypterus) granosus, py. $8-12$, pl. 2 , figs. $\mathrm{r}-2$, afterward considered a cockroach by Goldenberg and others.

Jordan, Johann Ludwig. Mineralogische bergund hüttenmännische reisebemerkungen, vorziiglich in Hessen, Thüringen, am Rheine und in saynaltenkirchnerischen gebiete. 80. Göttingen. 1803.

Not seen ; said to contain, on p. 199, some reference to fossil insects.

Judd, John Wesley. The secondary rocks of Scotland. Second paper. On the ancient volcanoes of the Highlands and the relation of their products to the mesozoic strata. Quart. journ. geol. soc. Lond., 30: 220-301, pl. 22-23. 8०. London. 1874.

Mentions, p. 274, the discovery of "elytra of two species of beetles" in lacustrine deposils at Ballypalidy, Co. Antrim, Ireland, which he refers to the miocene. These beetles were figured by Baily (q. v. in Appendix).

Karg, Joseph Maximilian. Ueber den steinbruch zu Oeningen bei Stein am Rheine und dessen petrefacte. Denkschr. vaterl. gesellsch. aertze $u$. naturf. Schwabens, I : 1-73. 80. Tübingen. 1805.

Not seen. It contains references to the insects, and is mentioned by Heer.

Kawall, J. H. Organische einschluisse im bergkrystall. Bull. soc. imp. nat. Moscou, 1876, no. 3, pp. I70-173. 80. Moscou. 1876.

Describes a caterpillar, Tineites crystalli, found in quartz from Siberia.

Keferstein, Christian. Die naturgeschichte des erdkörpers in ihren ersten grundziigen dargestellt. 2 v. 80. Leipzig. I834. I er theil, pp. I I, 394; $2^{\text {er }}$ theil, pp. 4,896 .

Abtheilung 2 (paläontologie), sechster abschnitt: Die fossilen insekten insekten, pp. 325-347; under 7 rachnids $F$ and G, pp. $370-371,375-376,378$. The species are enumerated in the two last-mentioned groups, but only the gevera in the bexapods; the names are very frequently misspelled.

Kendall, J. D. Interglacial deposits of West Cumberland and North Lancashire. Quart. journ. geol. soc. Lond., 37 : 29-39, pl. 3. 80. London. 1881.

Records the occurrence of elytra of beetles in deposits at Drigg, p. 34, and St. Bees, p. 35, without mention of names.

Kirby, W. F. A synonymic catalogue of diurnal Lepidoptera. 80. London. 1871. pp. 7, 690. Supplement, March, 187I-June, 1877. 80. London. 1877. pp. $7,69 \mathrm{I}-883$.

Iocludes the few fossil species.

Kirkby, James W. On the remains of insects from the coal measures of Durham. Geol. mag., 4: 388-390, pl. 17, figs. 6-8. 80. London. 1867.

Describes and figures without names two or three orthopterous insects from near Claxheugh.

Knorr, Georg Wolfgang. Lapides, ex celeberrimorum virorum sententia diluvii universalis testes, quos in ordines ac species distribuit, suis coloribus exprimit aeris incisos in lucem mittit et alia naturae miranda addit : - Sammlung von merkwürdigkeiten der natur und den alterthümern des erdbodens, zum beweis einer allgemeinen sündfluth nach der më̈. nung der berühmtesten maenner aus dem reiche der steine gewiesen und nach ihren wesentlichen arthen, eigenschafften, und ansehen, mit farben ausgedruckt, und in kupffer herausgegeben, in Nürnberg 1750 . With second title: Sammlung von merckwürdigkejten der natur und alterthümern des erdbodens welche petrificirte körper enthält ausgewiesen und beschrieben (erster theil). fo. Nüremberg. I755. 2 t. p., pp. (2), 32, t. p. to atlas, tab. $1-3^{8}(=57$ pl. $)$.

Pl. 33 contains six figures, five of irsects from Oeningen, the oniy distinguishable ones being three of odonate larvae, explained on p. 27. To this work is appended, pp. 29-32, a letter from Mylius to von Haller, entitled Besclareibung einer neuen gröndländischen thierpflanze. Bound up with the same is the following:-

Knorr, G. W. Die naturgeschichte der versteinerungen zur erläuterung der knorrischen sammlung von merkwürdigkeiten der natur herausgegeben von Johann Ernst Immanuel Walch. Erster theil. fo. Nürnberg. 1773. pp. (6), 187.

This contains a further explanation of the plate on p. $18 \mathrm{r}$ in which the insects are called libellen, and which is preceded by an account (pp. 1 $7 \mathrm{r}-180$ ) of what was then known of fossil insects, entitled Die entomolithen und helmintholithen.

Koch (Friedrich) Carl Ludwig und Berendt (Georg Carl). Die im bernstein befindlichen crustaceen, myriapoden, arachniden und apteren der vorwelt. fo. Berlin. I854. t. p., pp. 4, 124, pl. 17. Berendt, Bernst. befindl. org. reste vorw., I er bd. Ie abth.

Edited, with additions of importance by Menge. to Myriapoda, 123 Arachnida, and 21 Thysanura are described and figured, besides numerous others briefly described in the notes which Menge adds to nearly every species, nearly or quite doubling the extent of the text. Menge adds on pp. 7-8 a list of the species in his collection.

Koehler, Friedrich. Ueber den libellulit von Solenhofen. Zeitschr. f. mineral. (Taschenb. ges. mineral., jahrg. 20), bd. 2 : 23I-233, pl. 7, fig. 3. 160. Frankfurt a. M. 1826.

With note by Hessel giving the opinion of Herold. The insect is referred to Aeschaa.

Translation : Account of a libellulite found at Solenhofen. Edinb. new phil. journ., 2 : 195, pl. 3, fig. 4. 80. Edinburgh. 1826.

The note is not appeoded.

Kolenati, Friedrich August. Ueber phryganiden im bernstein. Abhandl. böhm. gesellsch. wissensch., [5], 6:15. 40. Prag. 1851.

Eigbt species or varieties are named but not described.

König, Charles. Icones fossilium sectiles. Centuria prima. fo. (London?, 1825) no t. p., pp. (4), pl. 19.

[Krantz, August.] Verzeichniss der von Dr. Krantz gesammelten, von Herrn Senator v. Heyden und Herrn Hauptmann v. Heyden in Frankfurt a. M. und von Herrn Dr. Hagen in Königsberg in der Palaeontographica bis jetzt beschriebenen und abgebildeten insecten, etc., aus dem braunkohlengebirge von Rott im Siebengebirge. Verhandl. naturh. ver. preuss. Rheinl. u. Westph., 24:313-316. 80. Bonn. 1867.

Enumerates 73 Coleopt., 25 Dipt., 1 I Neuropt., 4 Hymenopt., 3 Arachn., 2 Hemipt., I Lepidopt., I Orthopt., - 120 species.

de Lafontaine, Jules. See de Borre, A. P.

Landgrebe, Georg. Ueber einen im polir-schiefe1 des Habichts-waldes aufgefundenen küfer. Neues jahrb. $f$. mineral., 1843: $137-142$. 80. Stuttgart $18+3$.

Describes an Aphodius. 
Langins, Carolus Nicolaus. Historia lapidum figuratorum Helvetiae, ejusque viciniae, in quâ non solum enarrantur omnia eorum genera, species et vires, aeneisque tabulis repraesentantur, sed insuper adducuntur eorum loca nativa, in quibus reperiri solent, ut cuilibet facile sit eos colligere, modo adducta loca adire libeat. 80 . Venetiis. 1708. 2 t. pp., pp. (26). 165, tab. 52 .

A single "Mf usca" from Oeningen is figured on pl. 7 , fig. 5 and mentioned on p. 39 .

Lartigue. Échantillons de bois fossiles provenant du gault de Lottinghen. Ann. soc. ent. France, (5), 6, bull. ent., p. I07. So. Paris. I\$76.

Exhibition of fossil wood perforated by insects, afterward reported on by Brongniart, C. (q. v.)

Latreille, Pierre André. See Faujas-de-SaintFond, B.

Leach, William Elford. See Henslow, J. S.

LeConte, John Lawrence. Address before the American association for the advancement of science at Detroit, Michigan, August 13, 1875. 80. Salem. 1875. t. p., pp. I8. Proc. Amer. assoc. adv. sc., xxiv : 1 -I8. So. Salem. 1876 .

The distribution of certain $\mathrm{N}$. American beetles directly indicates a survival from cretaceous or even earlier times, pp. $4 \rightarrow 7$.

IeConte, J. L. See also Dana, J. D.

Lefebvre, Alexandre. Observations relatives à l'empreinte d'un lépidoptère fossile (Cyllo sepulta) du Docteur Boisduval. Ann. soc. ent. France [2], $9: 7$ I-88, pl. 3 , ii.

An argument to show that Boisduval had wrongly interpreted both the neuration and the markings of the wings. Reproduced in Scudder's Fossil butterflies, pp. 17-25, pl. 1, figs. 14-16.

Leidy, Joseph. See Deane, J.

Iesquereux, Leo. Botanical and palaeontological report on the geological state survey of Arkansas. Owen, Second rep. geol. reconn. Arkansas, pp. 295-399, pl. I-6. So. Philadelphia. 1860 .

Contains description, p. 314 and figure, pl. 5, fig. 1 I, of Blattina venusta from carboniferous rocks of Frog Bayou.

Lesser, Friedrich Christian. Lithotheologie, das ist: Naturliche historie und geistliche betrachtung derer steine. I60. Hamburg. 1735. pp. 48, $300,(52)$, pl. IO.

In the seventh chapter, fourth division, fifth book: Von versteinerten thieren auf erden, so kein blut haben, pp. 553-56r, he reviews what is known of fossil insects in his day.

In the Hamburg edition of 1751 (pp. $48,1488, \mathrm{pl}$. 10) the same appears on pp. $633^{-6} 39$.

Lhwyd, E. See Luidius, E.

van der Linden, Pierre Léonard. Notice sur une empreinte d'insecte, renfermée dans un échantillon de calcaire schisteux de Sollenhoven, en Bavière. $4^{\circ}$. (Bruxelles. 1827.) pp. 9, pl. Nouv. mém. acad. roy. sc. Brux., 4: 245-253, pl. $4^{\circ}$. Bruxelles. I 827 .

Describes and figures Aeschna antiqua.

von Linné, Carl. Oeländska och gothländska resa på riksens högloflige ständers befallning förrättad åhr 1741 ; med anmärkningar utj oeconomien, natural-historien, antiquiteter, \&c. med \&tstillige figurer. 160. Stockholm och Upsala. 1745. pp. ( 14$), 344,30,2$ maps, pl. figs.

Contains a mere mention, p. 59, of finding some small insects in a fossil state near Glömminge in Oeland.

Translation : Reisen durch Oeland und Gothland welche auf befehl der hochlöblichen reichstände des königreichs Schweden im Jahr I74I angestellt worden. 160. Halle. 1764. pp. (32), 364, (24), 2 maps, 2 pl.

The same on p. 68 . von Linné, C. Wästgöta resa på riksens högloflige ständers befallning förrättad âr 1746 . Med anmärkningar uti oeconomien, naturkunnogheten, antiquiteter, inwảrnarnes seder och lefnads-sätt, med tilhörige figurer, I60. Stockholm. I747. pp. (12), $2 S_{4},(19)$, pl. 5 .

Refers, on p. 24, to finding beetles in the limestone of Kinnekulle.

Translation : Reisen durch Westgothland, welche auf befehl der hochlöblichen reichsstände des königreichs Schweden im jahr 1746 angestellt

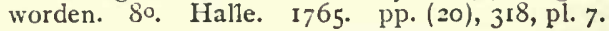

Not seen. The same (probably) is found on p. 30 .

[von Linné, C.]. Museum tessinianum, opera illustrissimi comitis, Dom. Car. Gust. Tessin. fo. Holmiae. I 753 . pp. (8), I 23, (9), pl. 14.

On p. 98 he enters Entomolithus coleoptri, unknown locality; which he likens to a carabid.

Lippi. [Lettre à M. Dodart.] Hist. acad. sc., 1705: 36-37. 4. Paris. 1706.

Account of the discovery of supposed bee-cells (probably corals) in the rocks of the Montagnes de Siout, Upper Egypt.

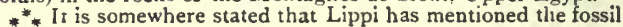
insects of Oeningen.

Loew, Hermann. Dipterologische beiträge |I abtheilung]. Offentl.prïf. Friedr.-Wiih. gymn. Posen, 1845: I-52, pl. $4^{\circ}$. Posen. I 845 .

Contains descriptions and figures of three copal Diptera.

Loew, H. Ueber den bernstein und die bernstein fauna. $4^{\circ}$. Berlin. I850. pp. 44. Progr. königl. realsch. Meseritz, pp. 1-44. 40. Meseritz. $185^{\circ}$.

Separate, Berlin edition not seen; of the other, pp. 28-44 are occupied by a general systematic review of the amber Diptera, of which many new genera and species are indicated with brief or no description. More than ro, $\infty$ o specimens were examined by Loew, and about 575 species indicated.

Loew, H. Ueber die dipteren fauna des bernsteins. $4^{\circ}$. Königsberg. 186r. pp. 13. Amtl. ber. versamml. deutsch, naturf., $35: 88-98$. 4\%. Königsberg. 1861 .

An important discussion of the problems suggested by a study of the Diptera of the Prussian amber, of which at this time 850 species were known to the author, and of which over 650 , belonging to ror genera, had been satisfactorily determined. These insects belong to a single district fauna, and represent only a fragment of that, viz.: those low flying Diptera which love moist places sheltered from the wind. The generic types which existed in the amber period have probably been preserved down to our time. Of all living types North American Diptera, especially those found from lat. $32^{\circ}$ to $40^{\circ}$ most nearly resemble the amber fauna; next to these, those of Europe.

Translation: On the Diptera or two-winged insects of the amber-fauna. 80. New Haven. 1864. pp. 20. Amer. journ. sc., [3], $37: 305-324$. 80. New Haven. I864.

Translation by R. von Osten Sacken, who adds a single brief note on living species common to Europe and America.

Loew, H. Monographs of the Diptera of North America ; prepared for the Smithsonian institution. Part I. ; edited, with additions, by R. Osten Sacken. 8o. Washington. I862. pp. 24, $221, \mathrm{pl} .2$.

References to amber Diptera, partiy original, will be found on pp. II, I7.

Loew, H. Berichtigung der generischen bestimmung einiger fossilen dipteren. Zeitschr. gesamml. naturw, 32: 180-191, taf. 5. So. Berlin. I868.

A revision of the tertiary Bibionidae described by Heer.

Lortet, Louis, et Chantre, Ernest. Études paléontologiques dans le bassin du Rhone; période quaternaire. Arch. mus. hist. nat. Lyon, I : 59-130. $4^{\circ}$. Lyon. 1876 .

Mentions the occurrence of insects at La Boisse, p. 104, and Sonnaz, p. sos. 
Lubbock, Sir John. The president's address. Trans. ent. soc. Lond., [3], 5, journ. of proc., I I $3^{-1} 3^{\mathrm{I}}$. So. London. I 867 .

Records, pp. 128-129, the progress during the year in the study of fossil insects.

Iubbock, $\mathrm{J}$. On the origin and metamorphoses of insects. I6\%. London. I874. pp. 16, I08.

Contains a chapter [v] on the origin of insects, in which, on p. 86 , is a general statement of the geological appearance of the different orders of insects.

Lubbock, J. Address read before the entomological society of London at the anniversary meeting on the roth January, r88r. 8o. London. r88r. pp. 17.

Refers, pp. 12-13, to recent researches on fossil insects, particularly by Goss and Scudder.

Lucas, Hippolyte. [Note sur les espèces de coléoptères décrites par Dalman dans son mémoire : Om insekter inneslutne i copal.] Bull. séancess soc. entom. France, 1878 , no. $7, p .75$. So. Paris. I 878 .

Remarks on the omission of these insects from Gemminger and Harold's Catalogus coleopterorum, and cites the species of all orders figured by Dalman.

Luidius, Edvardus. Edvardi Luidii apud oxonienses cimeliarchae ashmoleani Lithophylacei britannici ichnographia. Sive lapidum aliorumque fossilium britannicorum singulari figura insignium, quotquot hactenus vel ipse invenit vel $\mathrm{ab}$ amicis accepit : distributio classica : scrinii sui lapidarit repertorium cum locis singulorum natalibus exhibens; additis rariorum aliquot figuris aere incisis: cum epistolis ad clarissimos viros de quibusdam circa marina fossilia et stirpes minerales praesertim notandis. Editio altera : novis quorumdam speciminum iconibus aucta; subjicitur authorio praelectio de stellis marinis, etc. 8o. Oxonii. 1760. pp. (16), I $56,(4), \mathrm{pl} .25$.

Epistola 3. Summarium literarum V. C. D. Richardi Richardson, M.D. De entrocho lapide, conchitis, et lithophytis seu plantis mineralibus agri eboracensis; de bufonibus mediis saxis inclusis, et depictis aliquot in schisto carbonaria insectis, po. 107-1r4, pl. 4, fig. 197 (4 figs). First edition, Lipsiae, r699, not seen.

Iyell, Sir Charles. On the boulder formation or drift, and associated fresh-water depusits composing the mud cliffs of eastern Norfolk. Proc. geol. soc. Lond., 3 : 17 1-179. 80. London. 1840.

Mention is made, p. 175 , of the discovery of three elytra of Coleoptera, which Curtis determines to be identical with living British species of Donacia and Copris.

Iyell, C. Elements of geology, or The ancient changes of the earth and its inhabitants as illustrated by geological monuments ; sixth edition greatly en larged and illustrated with 770 woodcuts. 80 . London. 1865. pp. 16, 794.

Contains references to fossil insects and some illustrations of them on pp. 243, 250, 255, 331, 425, 491. Earlier editions not examined.

MacCulloch, John. On animals preserved in amber, with remarks on the nature and origin of that substance. Quart. journ. sc. lit. arts, 16: $6: 1-48$. So. London. I 823 I823.

Froriep, Notizen, 6, no. I1 4, pp. 49-51. 40. Erfurt.

Mainly devoted to describing the methods of distinguishing amber from other gums; insects and other animals are only mentioned in a general way.

McIntire, E. S. See Elrod, M. N., and McIntire, E. S.

McLachlan. Robert. Note sur l'insecte fossile décrit par M. P. deBorre sous le nom de Breyeria borinensis. Comptes rendus sonent. Balr. 41 : 5-6. So. Bruxelles. I 877 .

Ann. soc. ent. Bely. 20:36-37. 8o. Bruxelles. I 877 . Considers the insect an ephemerid.

McLachlan, R. Did flowers exist during the carboniferous epoch? Nuture, 19:554. $4^{\circ}$. London. IS79.

Breyeria is an ephemerid.

McLachlan, R. The same. Nature, $20: 5-6.4^{\circ}$ London. IS79.

Response to Mr. Wallace, disputing the lepidopterous nature of Breyeria borinensis.

McLachlan, R. See Anon.

Mahr, Carl Hermann. Beitrag zur kenntniss fossilen insecten der steinkohlen formation Thuringens. Neues jahrb. f. mineral., 1\$70: $282-2 S_{5}$, figs. So. Stuttgart. I\$70.

Description and figure of two species of Blattina from Ilmenau.

Malepeyre. See Buckland, W.

Malfatti, Giovanni. Osservazioni sopra alcuni insetti fossili dell' ambra e del copale. So. Milano. 1878. pp. 15. Atti soc. ital. sc. nat., 21 : 18I-195. So. Milano. I $\$ 78$.

Of a general nature, but contains at the close a list of additions to the Museo cuico with remarks; and three pages of bibliography are appended.

Malfatti, G. Due piccoli imenotteri fossili dell' ambra siciliana. $4^{\circ}$. [Roma. I88I.] pp. 4, figs. Atti accad. linc., (3), trans., $5: 80-83,2$ figs. $4^{\circ}$ Roma. I88 r.

Describes and figures a Myrmar and a Tapinoma.

Mantell, Gideon Algernon. A tabular arrangement of the organic remains of the county of Sussex. Trans. geol. soc. Lond., (2), 3: 201-216. $4^{\mathrm{O}}$. London. 1829 .

Reference is made on p. 20 to the occurrence of larval cases of Phryganidae in the silt or blue clay of Lewes Levels.

Mantell, G. A. The wonders of geology. First American from third London edition. 2 vols. 160. New Haven. I839. - Vol. I, pp. I6, I-428, front., pl. 4 ; vol. 2, pp. 7, 429-804 (24), pl. 6-ro.

"Fossil insects" (of Aix). I : 247-250, tab. 45. "Insects of the coal formation." $2: 679-680$.

Mantell, G. A. The same: 4 th ed. London, 1840. 6 th ed. 2 v. 160. London, I 848 . - Vol. r, pp. I 5 , 482 ; vol. 2 , pp. $483-93^{8}$, plates as above. 7 th ed. revised and augmented by $\mathrm{T}$. Rupert Jones. $2 \mathrm{v}$. I60. London. - Vol. I, pp. 24, I-480, (r857) ; vol. 2, pp. I6, 48 I-IoI9 ( 1858$)$.

Mantell, G. A. The medals of creation, or First lessons in geology and in the study of organic remains. 2 vols. I60. London. I844. - Vol. I, pp. 28 , I-456, pl. I, 3-6; vol. 2 , pp. 6, 457-Ior 6, pl. 2 .

Fossil insects and spiders, pp. 570-584, with woodcuts 122124.

Mantell, G. A. The same: $2 \mathrm{~d}$ edition entirely rewritten. 2 v. $16^{\circ}$. London. I854. - Vol. I, pp. 32, I-446; vol. 2, pp. I I, 447-930, plates as before.

Mantell, G. A. Notes on the wealden strata of the Isle of Wight, with an account of the bones of iguanodons and other reptiles discovered at Brook Point and Sandown Bay. Quart. journ. geol. soc. Lond., 2, i: $91-96$. So. London. I846.

In the closing paragraphs brief reference is made to elytra of "two or more species of Coleoptera" at Wateringbury.

Mantell. G. A. Geological excursions round the Isle of Wight and along the adjacent coast of Dorsetshire; illustrative of the most interesting geologi- 
cal phenomena, and organic remains. 160. London. 18.47. pp. 428, pl. 20.

Refers to the discovery of fossil insects in tertiary and wealden beds at pp. 140, 400 .

Mantell, G. A. A brief notice of organic remains recently discovered in the wealden formation. Quirt. jourm. geol. soc. Lond., 5: 37-43, pl. 3. 80. London. 1849.

A brief notice, p. 39 , of elytra of Coleoptera from the "freshwater strata above the oolite in Buckinghamshire:" two of these are rigured in detail, but no suggestion is made of their atinities.

Maravigna, Carmelo. Insectes dans l'ambre. Rov. zool., I : 16S-169, followed by remarks of Guérin Meneville, pp. 169-170, pl. 1. So. Paris. 1838 .

Maravigna's note is upon the conditions of occurrence of Sicilian amber. Guérin figures and enumerates and occasionally names about fifteen species, mostly Coleoptera, Hymenoptera, and Diptera.

Massalongo, Abramo Bartolommeo Pr. Monografia delle nereide fossili. 8o. Verona. 1855. pp. 35 , pl. 6.

In an appendix, pp. 3 r-32, he enumerates five species of insects from Monte Bolca.

Massalongo, A. B. P. Prodromo di un' entomologia fossile del M. Bolca. Studii paleont., $p p$. I 1-21, tab. I (pars.), 2. 80. Verona. 1856.

Describes seven insects of different orders.

Massalongo, A. B. P. Sopra due larve fossili di Libellula dei terreni mioceni di Sinigallia. Studii paleont., pp. 22-23, tab. I, figs. 8-13. 80. Verona. I8 56 .

The larvae are referred to two of Heer's species from Oeningen.

Massalongo, A. B. P. Compendium faunae et florae fossilis bolcensis.

Not seen ; nor have I been able to find a single reference to it in bibliographies, and presume it is still unpublished. It is thus referred to in several places by the author in other publications; see Studii paleont., p. 14 , etc.

Massalongo, A. B. P. e Scarabelli, G. Studii sulla flora fossile e geologia stratigrafica del Senigalliese. fo. Inola. 1859 . pp. 8, 506, map, pl. 45.

Parte $1^{*}$ Geologia stratigrafica is by Scarabelli; parte $2^{*}$ Flora fossile by Massalongo. Insettion p. 25, contains a nominal list of species.

Mayr, Gustav Leopold. Vorläufige studien über die Radoboj-formiciden in der sammlung der $\mathrm{k} . \mathrm{k}$. geologischen reichsanstalt. 80. Wien. I867. pp. 16, pl. 1. Jahrb. geol. reichsanst., 17:47-61, taf. I. 8. Wien. 1867.

A revision of the specimens described by Heer with reference to modern genera. See also Heer, $O$.

ABstract : On fossil insects. Quart. journ. geol. soc. Lond., 23, ii : 7. 8o. London. 1867.

Mayr, G. L. Die ameisen des baltischen bernsteins; mit 106 figuren auf fün tafeln. Beitr. naturk. Preussens, 1, pp. 4, 102, (10), tab. 5. $4^{\circ}$. Königsberg. 1868.

Extended descriptions of forty-nine' species and twenty-three genera, with some preliminary general observations, including a review of previous literature, and a comparison of amber species with modern types and those of Radoboj.

Medlicott, H. B. and Blanford, IV T. A manual of the geology of India; chiefly compiled from the observations of the geological survey; published by order of the government of India. 80 . Calcutta. 1879. 2 vol. and map. Vol. 1. Peninsular area, pp. 18, 80, I-444. Vol. 2. Extrapeninsular area, pp. $445-817$, pl. 2 r.

On pp. $152,154,314$ are references to insects found in the mesozoic and tertiary deposits of central India.
Meek, Fielding B., and Worthen, A. H. Notice of some new types of organic remains from the coal measures of Illinois. Proc. acad. nat. sc. Philad., 1865;41-53. So. Philadelphia. IS65.

Describe Anthracerpes typus as a myriapod and Palaeocampa anthrax as an insect, - both afterwards considered as worms.

Meek, F. B., and Worthen, A. II. Preliminary notice of a scorpion, a Eurypterus, and other fossils, from the coal-measures of Illinois. Am. journ. sc. arts, [2], 46: 19-2S. So. New Haven. I 868.

Afterwards described more fully in the Geological survey of Illinois. Among the "other fossils" are two myriapods.

Meek, F. B., and Worthen, A. H. Articulate fossils of the coal measures. Worthen, Geol. surv. Ill., 3, ii, palaeontology, pp. 540-565, figs. 8o. "1. p. 1868 .

Describe and figure, pp. 556-565, two myriapods and two arachnids, with a Note on the genus Palaeocampa, p. 565, first described as a caterpillar, but here considered a worm.

Meigen, Johann Wilhelm. See Rathke, M. H.

Meinecke, Johann Christoph. Vermischte anmerkungen über verschiedene gegenstände, sonderlich des steinreichs. Naturforscher, st. 20: 185-210. 160. Halle. 1784 .

The first part, pp. $186-189$, is devoted to amber, as occurring in which he mentions various insects and Gryllus domesticus in particular.

Menge, A. Ueber die scheerenspinnen, Chernetidae. $4^{\circ}$. [Danzig. I8 55.] pp. 43, pl. 5. Neueste schrift. naturf. gesellsch. Danzig, $1_{5}$, heft 2 [art. 2]. $4^{\circ}$. Danzig. i\$55.

Seven of the fifteen species described and figured are from amber.

Menge, A. Lebenszeichen vorweltlicher, im bernstein eingeschlossener thiere. Progr. petrischule Danzig, pp. 1-32. $4^{\circ}$. Danzig. $185^{6}$.

Contains a valuable systematic review of the species in the author's collection, with occasional brief descriptions. The collection is one of the largest ever made, containing 67 Myriapoda of 31 species, 674 Arachnida of more than 550 species, and 3102 Insecta, of which even the genera are rarely enumerated, but only separated by families.

Menge, A. Ueber ein rhipidopteron und einige andere im bernstein eingeschlossene thiere. Also entitled: Ueber ein rhipidopteron und einige helminthen im bernstein. 8o. Danzig. 1866. t. p., pp. 8, figs. Schriften naturf. geselisch. Danzig (2), I, ii-iv. 8o. Danzig. 1866 .

The strepsipteron is described and figured under the name of Triaena tertiaria, and figures are given of a Chironomus to which a Mermis is found attached.

Menge, A. Ueber einen scorpion und zwei spinnen im bernstein. 80. Danzig. 1869. pp. 9. Schrift. naturf. gesellsch. Danzig, (2), 2, ii. 80. Danzig. 1869. Menge, A. See also Koch, F. C. L. und Berendt, G. C. ; and Pictet-Baraban, F. J. et Hagen, H. A.

Mercati, Michael. Michaelis Mercati samminiatensis Metallotheca opus posthumum, auctoritate, \& munificentia Clementis XI. pontificis maximi e tenebris in lucem eductum; opera autem, \& studio Joannis Mariae Langisii archiatri pontificii illustratum. fo. Romae. 1717. pp. 64,378 , (18), pl. 6, figs.

Arm. 5, cap. 9: De succino, pp. 87-9o, contains on p. 89 figures of some half dozen insects in amber which are enumerated in a single line on p. 88 .

von Meyer (Christian Erich) Hermann. Indusia. Ersch u. Gruber, Allg. encycl. wissensch. u. künste, sect. 2 , th. 18, s. 1 $36.44^{\circ}$. Leipzig. 1840.

von Meyer, C. E. H. Insekten, fossile. Ersch. u. Grüber, Allg. encycl. wissensch. u. kunste, sect. 2, th. I8, s. 536-541. 40. Leipzig. I840.

A review of the literature, with nothing new. 
von Meyer, C. E. H. Fische und insekten der braunkohle bei Westerburg in Nassau. Neues jahrb. mineral., IS51 : 677. So. Stuttgart. 1851 .

Brief notice of the discovery of two Hies.

von Meyer, C. E. H. Mittheilung an professor . Bronn. Neues jahrb. mineral., I852: 465-468.

Notices, p. 467 , Heyden's Dicerca Taschei; his discovery of insect borings in wood from the brown coal; and his statement that Xylophagus antiquus is a Bibio.

von Meyer, C. E. H. Vogel-federn und Palpipes priscus von Solenhofen. Netues jahrb. mineral., I 861 : 56r. 8o. Stuttgart. I86r.

A brief notice of seven new specimens of Palpipes.

von Meyer, C. E. H. Zu Palpipes priscus aus dem lithographischen schiefer in Bayern. Palaeontograph., 10: 299-304, tuf. 50, figs. 1-4. 4\%. Cassel. 1863 .

A detailed description of this arachnid from several specimens.

von Meyer, C. E. H. See Jordan, H. und Meyer, (C. E.) $\mathrm{H}$.

Michelin. [Sur] un travail imprimé de M. Hoeminghaus, relatif à une espèce fossile du genre Phrygane. Ann. soc. ent. France, (2), 3, bull. cnt., 30-31. 8o. Paris. 1845.

Miller, S. A. The caenozoic or tertiary period. fourn. Cinc. soc. nat. hist., 4 : 93-144. 80. Cincinnati. I88I.

Gives lists of the tertiary insects described from North America.

Miller, S. A. The American palaeozoic fossils : a catalogue of the genera and species, with names of authors, dates, places of publication, groups of rocks in which found, and the etymology and signification of the words, and an introduction devoted to the stratigraphical geology of the palaeozoic rocks. 80 . Cincinnati. 1877. Pp. I 5, 253.

Arachnida, Myriapoda and Insecta, pp. 224-226.

Millière, Pierre. Observations relatives à l'empreinte d'un hémiptère fossile (with note by Signoret, V., and Fairmaire, L.). Ann. soc. ent. France, (3), I : 9-11, pl. $3^{11 .}$ 8o. Paris. 1853.

Describes under the name of Aphis longicaudus, an insect from the "schiste marneux" of Amberieux, Ain.

Moore, Charles. On the palaeontology of the middle and upper lias. Proc. Somersetsh. archaeol. nat. hist. soc., $2: 61-76$. 80. Taunton. 1865-1 866.

His collection of lias insects consists of about 1000 specimens. "The families represented at Ilminster include Libe]lula, Neuroptera, Orthoptera, Homoptera, Diptera and Coleoptera."

Moore, C. On the zones of the lower lias and the Avicula contorta zone. Quart. journ. geol. soc. Lond., I 7, i : 483-516, pl. I 5-16. 80. London. I 861 . On p. 513 mentions the occurrence of Carabidae at Vallis.

Moore, C. Notes on a plant and insect bed on the Rocky River, New South Wales. Quart. journ. geol. soc. Lond., 26 : 261-263, pl. 18, figs. 2-11. 80. London. 1870.

Brief notice of the insects, about ten species of beetles, which are figured. An abstract with the same title (excepting the omission of the word Notes) on p. 2 of same, with discussion, which does not touch the insects. An abstract will also be found in Phil. mag., 39: 463. 80. London. 1870.

Morris, John. A catalogue of British fossils, comprising all the genera and species hitherto described: with references to their geological distribution and to the localities in which they have been found. So. London. 1843. pp. I1, 222.

Insecta, p. 69 .
Morris, J. The same. Second edition, considerably enlarged. So. London. IS54. pp. 8, 372. Insecta, pp. 116-118.

Morris, J. On some sections in the oolitic district of Lincolnshire. Quart. journ. geol. soc. Lond., 9, i : 317-344, pl. I4. So. London. IS 53 .

Mentions the occurrence of insects on p. 324 and note.

Morris, IVilliam. Did flowers exist during the carboniferous epoch? Nature, 20:404. 8०. London. IS79.

Nutices a "Carbonaceous impress on a piece of shale from the Slievardagh coal fieid, Tipperary" which "appears" to him "to be a butterfly."

Mortillet, Gabriel. Description d'une nouvelle espèce de coléoptère fossile (Donacia Genin) trouvé dans les lignites de Sonnaz. Bull. soc. hist. nat.Savoie, I 850 , p. I 35 .

Les alpes, 1850, no. 5 .

Arch. sc. phys. nat., I $5: 78-79$. 80. Genève. 1850. Description of the species. Only the last reference seen.

Motschoulsky, Victor. Lettre à M. Ménétriés. Etudes entom., 5: 3-38, pl. 160. Helsingfors. I 856.

Contains, pp. 25-30, a notice of Menge's collection of amber insects with descriptions, pp. $25-27$, and figures (in the single plate) of thirteen Coleoptera. Also, p. 34 , a brief notice of Heer's collection of Oeningen insects.

Motschoulsky, V. Genres et espèces d'insectes publiés dans différents ouvrages. Supplément au vi vol. des Horae societatis entomologicae rossicae. 8o. St. Pétersbourg. I 868 . t. p., pp. I I 8.

Contains a list, p. 103, of Insectes contenus dans le succin described by the author.

Mourlon, Michel. Géologie de la Belgique. 2 v. $8^{\circ}$. Not seen. The fossil insects of Belgium are treated, according to de Borre, Comptes-rendus soc. ent. Belg., (3), no. $3, p .{ }_{3} \mathrm{~s}$.

Müller, Johannes. Fossile fische. Middendorff's Sibirische reise, 1, i : 259-263, pl. $11.44^{\circ}$. St. Petersburg. I 848 .

Refers in three lines, p. $26 \mathrm{I}$, to the ephemerid larva found by Middendorff, which is figured pl. $1 \mathbf{1}$, fig. 7 .

Münster, George, Graf $z u$. Fossile fische, sepien, krebse, Monotis salinaria, saurier, algaciten von Oeningen, schildkröte in lias von Altdorf, Clymenia glossopteris, folliculites ; tertiär formation in Norddeutschland. Neues jahrb. mineral., I834: 42-43. 8o. Stuttgart. I 834 .

Mentions the reception of a beetle from Solenhofen and insects from Oeningen.

Münster, G. Insekten in lias. Neues jahrb. mineral., 1835 ; 333. So. Stuttgart. I835.

Has discovered lias insects in the neighborhood of Brzezina.

Münster, G. See Germar, E. F. Beschreibung einiger neuen fossile insecten (1842), where some of the names are given by Münster.

Münster, G. See also Cotta, B.

Murchison, Sir Roderick Impey. On a fossil fox found at Oeningen near Constance; with an account of the deposit in which it was imbedded. Trans. geol. soc. Lond., (2), 3: 277-290. pl. 33-34. $4^{\circ}$. London. 1832.

The insects, pp. $286-287$, pl. 34 , are described by Curtis, with a mention of others determined by Samouelle; only a dozen species in all are mentioned; those figured are Odonata.

Murchison, R. I. The silurian system, founded on geological researches in the counties of Salop, Hereford, Radnor, Montgomery, Caermarthen, Brecon, Pembroke, Monmouth, Gloucester, Worcester and Stafford; with descriptions of the coal fields and overlying formations. $4^{\circ}$. I.ondon. 1839. pp. 32, 768 , pl. 37 . 
Murchison, R. I. Outline of the geology of the neighbourhood of Cheltenham. A new edition, augmented and revised by James Buckman and $H$. E. Strickland. So. London. I845. pp. I Io, map, sect., pl. 13 .

The first edition makes no allusion to fossil insects. The additions unon that subject in this ase by Brodie (q. v.) and Buckman. The insects are catalogued on pp. $68,8 \mathbf{r}-82$ and figured on pl. $4,8,9$. Reference is also incidentally made in several places to the insect beds of the district, but without special mention of their contents.

Murchison, R. I. Siluria. The history of the oldest known rocks containing organic remains, with a brief sketch of the distribution of gold over the earth. So. London. 1854 . pp. $16,523, \mathrm{pl} .37$.

Notices insects of the coal, p. 284 .

Murchison, R. I. Siluria. The history of the oldest fossiliferous rocks and their foundations; with a brief sketch of the distribution of gold over the earth. 3 d edition (including the silurian system) with maps and many additional illustrations. So. London. I859. pp. 20, 592, (2), pl. (2), 41, maps 2.

Brief reference to and figure of an insect "allied to Corydalis" from Coalbrookdale on pp. 320-321.

Murchison, Sir Roderick Impey, and Lyell, Sir Charles. On the tertiary fresh-water formations of Aix in Provence, including the coal field of Fuveau ... with a description of fossil insects contained therein by John Curtis. Proc. geol. soc. Lond., I : I 50-1 51. So. London. I829.

Accompanied, p. 151 , by "Observations on the fossil insects" mentioned, by John Curtis, afterwards described and figured by the same. See Curtis, J.

Murray, Andrew. Notes on some fossil insects from Nágpur. Quart. journ. geol. soc. Lond., I6: I82-185, I 89, pl. 10, figs. 66-70. 80. London. I 860 .

Occurs as a separate note in an article by Hislop, S., "On the tertiary deposits associated with the trap-rock in the East Indies, with descriptions of the fossil shells by the Rev. Stephen Hislop, and of the fossil insects by Andrew Murray, and a note on the fossil Cypridae by T. Rupert Jones." Thirteen Coleoptera ( Buprestidae and Curculionidae) are mentioned and figured; only one is named.

Mylius, G. F. Memorabilium Saxoniae subterraneae, pars prima; i. e. Des unterirdischen Sachsens weltsamer wunder der natur; erster theil. Worinnen die auf denen steinen an kräutern, bäumen, blulumen, fischen, thieren und andern dergleichen besondere abbildungen, so wohl unsers Sachsenlandes als deren so es mit diesen gemein haben, gezeiget werden, mit vielen kupffern gezieret. $4^{\circ}$. Leipzig. I 709 . pp. (6), 80, (19), front., pl. (13), fig.

Remarks on a fossil "wurm, welcler einem seidenwurm nicht ungleich scheidet," p. 56 .

Nicholson, Henry Alleyne. A manual of palaeontology for the use of students, with a general introduction on the principles of palaeontology. 8o. London. I872. pp. I8, 601, figs. 40I.

Chapter xvii. Araclınida, Myriapoda, and Insecta occupies pp. $181-197$ and figs. $124-130$. This very brief notice is mostly confined to the older insects.

Nicholson, H. A. The same. Second edition, revised and greatly enlarged. 2 vol. 8०. Edinburgh and London. I879. Vol. I, pp. I8, 5 I I ; vol. 2, pp. I 2, 531, figs.

Vol. 1 contains a chapter (20) on Arachnida, Myriapoda, and Insecta, pp. 398-409, figs. 250-258; slightly enlarged from the preceding.

Nicholson, H. A. The ancient life-history of the earth, a comprehensive outline of the principles and leading facts of palaeontological science. 80. Edinburgh and London. I877. pp. 19, 407.

Contains nothing original in insects: a few are figured.
Nicholson, H. A. See also White, C. A., and Nicholson, H. A.

Nöggerath, Jacob. Notizen iber fossile anima. lien. Arch. ges. naturl., $2: 323-325$. 8o. Nürnberg. I 824 .

Mentions the discovery of fossil beetles (p. 325) at Orsberge on the Rhine.

Novák, Ottomar. Fauna der cyprisschiefer des egerer tertiärbeckens. Wien. 8०. 1877. pp. 26 , pl. 3. Sitzungsb. akad. wiss. Wien, 76 : abth. I, math. nat. classe, 7 I-96, taf. $\mathbf{1}-3$. So. Wien. IS78.

Descriptions and illustrations of nineteen insects of various gronps, but mostly Diptera.

Novák, O. Ueber Gryllacris bohemica, einen neuen locustidenrest aus der steinkohlenformation von Stradonitz in Böhmen. So. IVien. IS80. pp. 6. pl. I. Fahrb. geol. reichsanst. Wien, $30: 69-74$, taff. 2. 1. So. Wien. ISSO.

Compares the new species with Gryllacris Brongniarti (Mantell), which also is figured, and to which it is closely allied. Reviewed by Scudder, Proc. Bost. soc. nat. hist., $21.8^{\circ}$. Boston. ז88.

d'Orbigny, Alcide Dessalines. Recherches zoologiques sur l'instant d'apparition, dans les âges du monde, des ordres d'animaux, comparé au degré de perfection de l'ensemble de leurs organes. Ann. sc. nat., (3), I $3: 228-236,2$ tables. 8o. Paris. I 850.

Insects are treated on pp. 232-233 and on both tables.

von Osten Sacken, Carl Robert Romanoff. See Loew, H.

Ouchakoff, Nicolas. Notice sur un termes fossile. Bull. soc. imp. nat. Mosc., $1838: 37-42$, pl. I. 8o. Moscou. 1838 .

Ann. sc. nat., (2), 13:204-207, pl. I B. 8o. Paris. I840.

Translation: Notice of a fossil termes. Calc. journ. nat. hist., $2: 74-78$. So. Calcutta. I842.

ABSTRACT : Notitz über eines fossilen termiten. Neues jahrb. mineral., I839: 122-123. 80. Stuttgart. I839.

Oustalet, Émile. Recherches sur les insectes fossiles des terrains tertiaires de la France; première partie. Insectes fossiles de l'Auvergne. $A n n$. sc. geol., 2, art. 3, pp. I-178, pl. 1-6. 8o. Paris. 1870. Oustalet, E. The same, entitled: Mémoire sur les insectes fossiles des terrains tertiaires de la France. Bibl. école hautes études, sect. sc. nat., art. 7, $p p .1-178, p l .1-6.80$. Paris. $187 \mathrm{I}$.

Studied descriptions of forty-five species, most of them new; they are mostly Diptera, especially Protomyiae and Bibiones, and Coleoptera, especially Rhynchophora. The characteristics of the groups to which the insects belong are given in detail, and references made to other fossil insects of the same groups. The whole is preceded by a chapter of 48 pages, containing a good history of our knowledge of fossil insects, and is followed by one of 17 pages of general results reached by a study of the one of 17 pages of general results reached by a study of the Auvergne fossil insects, which are found to show a mingling of
indigenous and of exotic forms, a Mediterraneau and American aspect, and a warmer climate than now.

An extended notice will be found in the Revue scient. France, $(2), 4: 136-137.4^{\circ}$. Paris. 1374. See also Giard, A.

Oustalet, E. Recherches sur les insectes fossiles des terrains tertiaires de la France; deuxième partie. Insectes fossiles d'Aix en Provence. [Premier fascicule. Coléoptères d'Aix.] Ann. sc. géol., 5, art. 2, pp. I-347, pl. I-6. 8o. Paris. 1874. [pp. I-1 36 and pl. I-2 Febr. 1 5, I874; pp. 1 37-347, pl. 3-6, Mai I 5, I 874 .]

Also [with prem. partie] under the title: Recherches sur les insectes fossiles des terrains tertiaires de la France. Thèse présentée à la faculté des sciences. 80. Paris. I874. pp. I-556, pl. I-I 2.

The second part describes 81 species after the same plan as in the preceding memoir. 32 of them are Rhyncophora. 19 
Staphylinidae, I Carabidae, and the rest scattered among various families; the inemoir opens with a cliapter of $7+$ pages on the geological relations of the gypsum beds of Aix.

Oustalet, E. Note sur une empreinte de diptère fossile des marnes du gypse des environs de Paris. Bull. soc. philom. Paris, [6], 9 : I6r. So. Paris. I872.

Not seen; title received from the author. Bibio Cbapuisi is described.

Oustalet, E. Paléontologie. Girard, Les insectes; traité élémentaire d'entomologie, I : I 70-180. So. Paris. 1873.

A good general account of fossil insects from the older to the newer strata.

Oustalet, E. Sur quelques espèces fossiles de l'ordre des thysanoptères. Bull. soc. philom. Paris, [6], I0: 20-27. 80. Paris. IS73.

Describes a new genus and three new species of Physopoda from Aix.

Oustalet, E. Insectes de l'ambre. Bull. soc. philom. Paris, [6], 10: 9\$-99. 80. Paris. I873.

A brief notice of various insects enclosed in a single block of amber in which Vaillant had detected a reptile. The insects are mentioned still more briefly in Vaillant's paper.

Oustalet, E. Sur un hémiptère de la famille des pentatomides. Bull. soc. philom. Paris, [6], 11 : 14-16. 8o. Paris. [1874] I877.

Describes Cydnopsis Heeri.

Oustalet, E. Les insectes fossiles de la France. La nature, 3: 33-36, figs. $4^{\circ}$. Paris. I874.

A popular account of the tertiary insects of $F$ rance, with figures of Bibio Edwardsi, Calosoma Agassizi and Cyllo sepulta.

Oustalet, E. Observation sur la communication de M. Filhol [Sur les vertébrés fossiles des dépôts de phosphate de chaux du Quercy]. Bull. soc.philom. Paris, [6], I I : 21. 80. Paris. [1874] 1877.

Analogies between the insect fauna of the oligocene of southern France on the one hand, and that of southern N. America at the present time, or of the oligocene of the Rocky Mountains on the other.

Oustalet, E. Réclamation sur une question de nomenclature. Bull. séances soc.entom. France, 1878 , vii: 72. 8०. Paris. 1878 .

Ann. soc. entom. France (5), 8, bull., 60-6I. 80. Paris. 1878 .

Bull. scient. dep. du Nord, (2), I : 105-106. 8o.

Lille. 1878 . (With notes by Giard.)

A claim that the name of the original describer of the species of Protonyvia referred by Brongniart to Plecia should still remain attached to them. Giard refers to the opinion of Loew regarding Heer's Protomyia.

Oustalet, E. See also Giard, A.

Owen, Richard. - Palaeontology, or A systematic summary of extinct animals and their geological relations. 2d edition. 8o. Edinburgh. I86r. pp. 16,463 .

The insects are briefly treated, without illustrations, on pp. 51-52. Nothing new is given except the expression of a doubt by Waterlouse whether the indusial limestone of Auvergne is to be referred to the cases of Phryganidae.

The first edition of this work was an excerpt from Vol. $\mathrm{I} 7$ of the Encyclopædia Britannica (8th ed. 1859), where the article occupied pp. 91-176, and the insects, in nearly the same words as in the later edition, occurred on pp. 102-103.

Packard, Alpheus Spring. Guide to the study of insects, and a treatise on those injurious and beneficial to crops; for the use of colleges, farm-schools and agriculturalists; with eleven plates and six hundred and fifty wood-cuts. $8^{\circ}$. Salem. I869 [1863-69]. pp. 8, 702, pl. II.

Has a section on Geological distribution, pp. $77-81$, with a plate ( $\mathrm{I}$ ) in the introduction, besides treating of the fossil species in the body of the work; especially in the Neuroptera, where pp. $582-584$ are given to a discussion of Eugereon, with a figure (572) and quotations from opinions expressed by Hagen and Ger- staecker in letters from the former. In the shird edition (1872) an appendix is added, in which, pp. $710-711$, a description and figure are given of Paolia. A figure of Arthrolvcosa is added in the jourth edition (1874) The preface to sixth edition (1575) contains on its second page a paragraph on the fossil insects publisled in America since the previous edition [iurnished by S. H. Scudder].

Packard, A. S. [On insect-remains occurring in nodules... north of Turner's Falls.] Bull. Essex inst., 3: I-2. So. Salem. I87 I.

Considers Palephemera mediaeva an aquatic coleopterous insect "beionging perhaps near the family Heteroceridae."

Packard, A.S. Our common insects ; a popular account of the insects of our fields, forests, gardens and houses; illustrated with four plates and 268 woodcuts. $16^{\circ}$. Salem. 1873 .

Contains a chapter (xiii) entitled Hints on the ancestry of insects, in which, and especially on pp. 157-159, the geological question is brietiy discussed.

Parkingon, James. Organic remains of a former world; an examination of the mineralized remains of the vegetables and animals of the antediluvian world; generally termed extraneous fossils. 2d edition. 3 vols. $4^{\circ}$. London. 1833. Vol. I, pp. I2, 460, (4), front., pl. I, 9; - vol. 2, pl. I4, 286, (26), front., pl. 19 ; - vol. 3, pp. 12 [10], 467, (20), front., pl. 22.

Entomolithi are treated in vol. 3, pp. $265-267$, and pl. 17, figs. 2-6; larvae of Odonata from Pappenleim being figured and some indistinguishable.insects copied from Luidius.

Peach, Charles IVilliam. An account of the fossil organic remains found on the south-east coast of Cornwall, and in other parts of that county. Trans. roy. geol. soc. Cornwall, 6:12-23. 80. Penzance. 1846 .

Mentions the discovery of elytra of beetles in alluvial matter lying about the roots of trees resting on clay at Port Mellin, p. 23 .

Peach, C. IV. On the fossiliferous strata of part of the south-east coast of Cornwall. Trans. roy. greol. soc. Cormwall, $7: 57-62$, pl. 3-4. So. Penzance. I865.

Mentions, p. 62, the nccurrence of elytra of beetles in similar situations as the preceding at Ready Money.

Peale, A. C. Report on the geology of the Green River district. Ann. rep. U.S. geol. surv. terr., I877, 5II-646, pl. 47-76. 80. IVashington. I879.

Contains, p. 535 , notice of the discovery of insects on Twin Creek, Wyoming Terr.; and pp. 633-639 a reprint of Scudder's description of Indusia calculosa from Horse Creek Valley, Wyoming; see also p. 528 .

Phillips, John. The neighborhood of Oxford, and jts geology. Oxford essays, 1855: 192-212. $8^{\circ}$. London. IS 55 .

A paragraph, p. 204, is given to the insects of the Stonesfield slate.

Phillips, J. Oxford fossils. No. 2. Geol. mag., 3, 97-99, pl. 6. 8o. London. I 866.

Describes and figures Libel!ula Westwoodii from the Stonesfield slate, and compares it with Aeschna Brodiei from the lias.

Phillips, J. Geology of Oxford and the valley of the Thames. $8^{\circ}$. Oxford. I 87 r. pp. 24, 523, pl. 17.

Contains, p. 123, fossils of the liassic period; pp. 173-r 74 , fossils of the Stonesfield beds, in both of which insects are referred to.

Phillips, J. See Conybeare, W. D., and Phillips, W., and Woodward, H. et al.

Pictet-Baraban, afterward's Pictet-de la Rive, François Jules (q. v.).

Pictet-de la Rive, François Jules. Résultat de ses recherches sur les insectes fossiles de l'ordre des névroptères contenus dans l'ambre. Actes soc. helv. sc. nat., $30: 69-70$. $8^{\circ}$. Genève. I 845 .

All specifically distinct from existing forms, but with one exception of existing genera. 
Pictet-de la Rive, F. J. Considérations générales sur les débris organiques qui ont été trouvés dans l'ambre et en particulier sur les insectes. Arch. sc. phys. nat., 2: 5-16. $8^{\circ}$. Genève et Paris. I 846.

Amber insects altogether differ specifically from living forms, a considerable number of genera are also distinct and there are two peculiar fanilies: Archaeides in the Arachnida and Pseudoperidides in the Neuroptera; a warmer climate than the present is indicated.

Translation: General considerations on the organic remains, and in particular on the insects, which have been found in amber. Edinb. new phil. journ., 41 : 391-40I. So. Edinburgh. I\$46.

Pictet-de la Rive, F. J. Traite élémentaire de paléontologic ou Histoire naturelle des animanx fossiles considérés dans leurs rapports zoologiques et géologiques. 4 vol. $8^{\circ}$. Genève. 1844-46. T. 4 . (IS 46 ), pp. 15, 458 , pl. 20 in text.

IV classe, Arachnides, pp. 87-89; V classe, Insectes, pp. 91-114; VI classe, Iyriapodes, pp. 115-116. No insects are figured.

Pictet-de la Rive, F. J. Traité de paléontologie ou Histoire naturelle des animaux fossiles considérés dans leurs rapports zoologiques et géologiques. $2^{\mathrm{e}}$ édition. 4 vol. $8^{\circ}$; atlas, $4^{\circ}$. Paris. $1853-57$. T. 2 (I854), t. p., pp. 727 ; atlas, pp. 32, pl. 56 .

Insectes, pp. 301-405; Myriapodes, p. 405; Arachnides, pp. 406-410; Atlas, pl. 40-4r. A few additions from Serres MS. are quoted.

Pictet-de la Rive, F. J. See also Germar, E. F., und Berendt, G. C.

Pictet-de la Rive, F. J, und Hagen, H. A. Die im bernstein befindlichen neuropteren der vorwelt. fo. Berlin. [18 56.] t. p., pp. 4I-I 25, pl. 5-8. Berendt, Bernst. befindl.org. reste vorw., 2 er bd. 1e abth. pars.

More than seventy species are described in full detail and admirably figured. Under the genera also Hagen gives gond accounts of the literature of fossil species and prefaces the whole with general observations of the amber Neuroptera. The work is mostly Hagen's. Some descriptions are by Menge. Description of the larva of a Phasma is also appended, p. 122.

Pidgeon, Edward. The fossil remains of the animal kingdom. $8^{\circ}$. London. 1830 . pp. (6), 544, (I), pl. (49).

Forms the supplementary volumes of Griffith's Animal kingdom of Cuvier. Insects are treated in a summary manner on pp. 493-495, but notling new is added, and none are figured.

Plateau, Félix. See de Borre, A. P.

Plinius Secundus, Caius. Naturalis historia. Liber 37 , section 72.

As translated by Bostock and Riley ( $8^{\circ}$, London, 1857 ) that part of the passage which mav refer to fossil insects reads as follows: "Other stones, again, derive their names from various animals ... scorpitis, frnm either the colour or the shape of the scorpion . Myrmecitis presents the appearance of an ant

Ponzi, G. Lavori degli insetti nelle lignite del Monte Vaticano. $4^{\circ}$. Loma. [I876.] pp. 3. Not seen.

Presl, Joannes Swatoplucus.' Additamenta ad Faunam protogaeam, sistens descriptiones aliquot animalium in succino inclusorum. Diliciae prasenses, I : 19I-210. I60. Pragae. I822.

Describes I species of Cynips, 6 Formica, I Tinea, 3 Tipula, 4 Musca, 2 Aranea, I Phalangium, and I Acarus. Noticed in Oken's Isis, 1823 : 374-375. $4^{\circ}$. Jena. 1823.

Prestwich, Joseph. On some of the faults which affect the coalfield of Coalbrookdale. Lond. Edinb. phil. mag., iv : 375-376. So. London. I834.

Proc. geol. soc. Lond., 2 : 18-20. So. London. I834.

In a notice of the fossils a beetle and a spider are mentioned, p. $376(20)$, as occurring in the iron-stone nodules at that place.
Prestwich, J. On the geology of Coalbrook Dale. Trans. geol. soc. Lond., (2), 5: 4I3-495, pl. 30-4 I. $4^{\circ}$. London. I 840 .

Contains a nolice, p. 446 , of three fossil insects (Curculloides [sic] Ansticii, C. Prestvicii and a neuropteron) from the locality; also entered in the table on p. 490.

Prévost, Constant. Observations sur les schistes calcaires oolitiques de Stonesfield en Angleterre, dans lesquels ont été trouvés plusicurs ossemens fossiles de mammifères. Ann. sc. natur., $4: 3^{89}$ 417, pl. 17-18. 8. Paris. IS24.

Refers merely, p. 393 , and in explanation of plates, p. 417 , to elytra of a Buprestis? figured pl. 18, fig. 26.

Procaccini Ricci, Vito. Lettera ... sugli entomoliti delle gessaje sinigagliesi. N'uor. ann. $s c$. natur., ann. 4, tom. $7, p p .44 S-456$. 80. Bologna. I842.

A general paper, in which on p. 449 it is stated that Coleoptera, Hemiptera, Lepidoptera, Neuroptera, Hymenoptera, D ptera and Aptera have been found at Senigaglia.

Quenstedt, Friedrich August. Handbuch der petrefaktenkunde. $8^{\circ}$. Tübingen. I852. pp. 6, 792, pl. 62 .

Arachnidae, pp. 306-309; Insecta, pp. 309-319. The 2d edition not seen.

Raffray, Achille. Note sur des insectes renfermés dans des morceaux de gomme copal. Ann. soc. ent. France, (5), 5, bull. ent., 125-126. 80. Paris. 1875 .

General notes based on a collection exhibited ; a single paragraph is devoted to insects.

Rathke, Martin Heinrich. Untersuchung über die bernstein-insecten. Oken's Isis, IS29:413. $4^{\circ}$. Leipzig. I829.

Mentions his large collection of amber insects collected in company with Behrendt ; the Coleoptera had been studied by Heyden and Schmidt, the Ichneumonidae by Gravenhorst, the Diptera by Meigen and Wiedemann.

Reichenbach, Heinrich Gottlieb Ludwig. See Geinitz, H. B.

Reuss, August Emanuel. Kurze übersicht der geognostischen verhältnisse Böhmens; fünf vorträge, gehalten im naturwissenschaftlichen vereine Lotos im jahre 1853 ; mit drei geologischen übersichtskarten. 8.. Prag. 1854. pp. I03, pl. 3 .

Refers, p. 59, to two scorpions and a spider from the carboniferous rocks of Buhemia.

Robert, Eugène. Lettre sur les observations faites en Danemarck, en Norwége et en Suède, et dans laquelle il parle du succin, etc. Bull. soc. gćol. France, 9: 114-1 8 . 8०. Paris. 1838.

The letter is addressed to M. Cordier. The amber containing insects is mentioned on pp. 114-115; the insects mentioned are Aphodius fossor, Buprestis, Galeruca, "altises", and "le bouclier," all on p. 114. It is quoted in the Royal society's catalogue under the title: De la disposition de la tourbe à Elseneur et des insectes qu'on y trouve.

Roemer, Ferdinand. On a fossil spider lately discovered in the coal measures of Upper Silesia. Kefort Brit. assoc. adv. sc., $1 \$ 65$, notices, 73. $8^{\circ}$. London. I 866.

Geol mag., $2: 468.8^{\circ}$. London. 1865.

These two are essentially the same with slightly differing titles; and are practically an abstract of the following.

Roemer, F. Protolycosa anthracophila, eine fossile spinne aus dem steinkohlen-gebirge Oberschlesiens. Nezes jahrb. f. mineral., 1866: 136-143, taf. 3 . 8. Stuttgart. I 866

Roemer, F. Notiz über ein vorkommen von fossilen käfern (coleopteren) im rhät bei Hildesheim. 
Zeitschr. deutsch. geol. gesellsch., 28 : 350-353, figs. So. Berlin. 1876 .

Describes and figures three species of Coleoptera, of which one is not named.

Roemer, F. Lethaea geognostica oder Beschreibung und abbildung der für die gebirgs-formationen bezeichnendsten versteinerungen, herausgegeben von einer vereinigung von paläontologen. I theil: Lethaea palaeozoica von F. Roemer. With secondary title: Lethaea geognostica oder Beschreibung und abbildung der für die einzelnen abtheilung der palaeozoischen formation bezeichnendsten versteinerungen. Atlas, mit 62 tafeln. $8^{\circ}$. Stuttgart. 1876.2 t. p., vorw. 2 p., taf. 62 (mit erläuterungen).

A few insects are figured on plates 31,47 and 56 .

Roemer, F. See Bronn, H. G., und Roemer, F.

Rolle, Friedrich. Ueber ein vorkommen fossiler pflanzen zu Obererlenbach (Wetterau). Neues jahrb. f. mineral., I877: 769-784. So. Stuttgart. 1877 .

Merely mentions, pp. $772-773$, the occurrence of remains of insects in the pliocene? beds of Ober Erlenbach.

Rondani, Camilio. Lettre sur les insectes du succin. Rev. zool., 3: 366-370. 80. Paris. I840.

Followed, p. 370, by remarks by Guerin-Ménéville. Rondani makes some corrections of generic determinations in Guerin's supplement to Maravigna's paper. Guerin speaks only of the imperfection of the specimens. See also Maravigna, C., in App.

Rost, Woldemar. De filicum ectypis obviis in lithanthracum wettinensium lobejunensium fosdinis. Halae. $8^{\circ}$. 1839 . pp. 31 .

Not seen. A ccording to Germar, the latter's Blattina didyma is described as a fern.

Roth, Johann Rudolph. Ueber fossile spinnen des lithographischen schiefers. Gel. anz. bay. akad. wiss., 32 : 164-167. fig. $4^{\circ}$. München. 1851 .

Neues jahrb. mineral., 1851 : $375-377$, pl. 4 B. fig. 8. $8^{\circ}$. Stuttgart. $185 \mathrm{I}$.

Describes two species of a new genus, Palpipes.

Rouchy, labbé. [Borings of Coleoptera in a trunk of fossil Walchia.] Petites nouv. entom., I : 551. $4^{\circ}$. l'aris. 1875 .

Salter, John William. On some species of Eurypterus and allied forms. Quart. journ. geol. soc. Lond., 19, i : 81-87, figs. $8^{\circ}$. London. 1863 .

Describes and figures as an Eurypterus some carboniferous fragments since recognized as myriapods.

de Saporta, Comte Gaston. Examen des flores tertiaires de Provence. Heer, climat pays tert., pp. 133-17I. 4 . Winterthur. 186r.

At the end of the section on the flora of Aix he refers, pp. r52-153, to the insects of the gypsum beds and their relations to the vegetation of the epoch.

de Saporta, G. Etudes sur la végétation du sud est de la France à l'époque tertiaire. Suppl. 1. Révision de la flore des gypses d'Aix; fasc. I : généralités. $8^{\circ}$. Paris. 1872. pp. 79, pl. 2. Ann. sc. nat., (5), bot., 15 : 277-351, pl. 15-16. 80. Paris. 1872 .

Notices the insects of Aix on pp. 70-7x [342-343]. Gives also a note by A. Giard, p. $69[34 \mathrm{I}]$, note, suggesting the presence at Aix of certain plants, from the occurrence of beetles presumed to feed upon them.

de Saporta, G. [Lettre à M. de Selys-Longchamps.] Compt. rend. soc. ent. Belg., (2), no. 23 : 8. $8^{\circ}$. Bruxelles. I 876.

Ann. soc. ent. Belg., 19: 4. 8o. Bruxelles. I 876 .

Lepidoptera could not have appeared before phanerogamous flowers. de Saporta, G. See also de Borre, A. P.; and Heer, $\mathrm{O}$.

de Saussure, Henri. Note sur un nouvel insecte hvménoptère fossile. So. [Paris. I852.] pp. 2, pl. Kev. mag. zool., (2), 4 : 579-5'2, pl. 23, figs. 5-6. 8. Paris. 1852 .

Describes and figures Pimpla antiqua from tertiaries of Aix.

Scarabelli, Giuseppe. See Massalongo, A. B. P. $c$ stcarabelli, G.

Schau-platz der natur oder gespräche von der beschaffenheit und den absichten der naturlichen dinge etc. Dritter theil. So. Wienn und Nürnberg. 1748. pp. (22), 592, (I I) front., pl. (33).

Refers to the occurrence of flies and beetles in amber, p. 347. A figure of a fossil odonate larva also appears on the plate opposite p. 426 (fig. F.).

Scheuchzer, Johann Jacob. Beschreibung der natur-geschichten des Schweizerlands dritter theil enthaltende vornemlich eine ober die höchsten alpgebirge an. 1705 getahne reise. $4^{\circ}$. Zürich. 1708. pp. (4), 208, pl. (9).

Refers, p. 68, to the occurrence of flies and spiders in amber (agdstein).

Scheuchzer, J. J. Piscium querelae et vindiciae expositae. $4^{\circ}$. Tiguri. 1708. t. p., pp. $3^{6}$, pl. 5 .

Mentions, p. 15, and figures, pl. 2, a "Scarabaeus in lapide fissili öningensi," as a relic of the deluge.

Scheuchzer, J. J. Herbarium diluvianum. fo. Tiguri. I709. t. p., pp. 44, pl. Io.

$\mathrm{Pl}$. 5. figs. $1-2$, p. 16 give figures and description of an odonate larva from Oeningen and a winged odonate from Moute Bolca.

Scheuchzer, J. J. Herbarium diluvianum; editio novissima duplo auctior. fo. Lugduni Batavorum. 1723. 2 t. p., dedic., pp. I19, (5), portr., pl. I4.

The same is found on the same plate, p. $2 \mathrm{r}$.

Scheuchzer, J. J. Museum diluvianum quod possidet J. J. S. 160. Tiguri. 1716. pp. (12), 107, (4). front.

Records four fossil insects, p. 106, from Oeningen, Monte Bolca and Querfurt.

Schilling, Samuel. See Gravenhorst, J. L. K. von Schlotheim, Ernst Friedrich. Die.petrefactenkunde auf ihrem jetzigen standpunkte durch die beschreibung seiner sammlung versteinerter und fossiler überreste des thier- und pflanzenreichs der vorwelt erläutert; mit I 5 kupfertafeln. $8^{\circ}$ (atlas, $4^{\circ}$ ). Gotha. I820. pp. $64,43^{8}$.

Pp. 42-44 relate to insects, specified under six lseads.

von Schlotheim, E. F. Nachträge zur petrefactenkunde; mit 2 I kupfertafeln. $8^{\circ}$. Gotha. I 822. pp. 12, 100 .

The same. Zweyte abtheilung; mit kupfertafeln. $8^{\circ}$ (atlas, $\left.4^{\circ}\right)$. Gotha. I 823 . pp. (4), I I 4 .

The secoud part contains on pp. $60-6 \mathrm{r}$, taf. 22, fig. ro, what the author looks upon as the larva and nest of a Myrmeleon.

Schmidel, Kasimir Christoph. Fortgesezte vorstellung einiger merkwürdigen versteinerungen mit kurzen anmerkungen versehen. $4^{\circ}$. Nürnberg. 1782. t. p., pp. 45 , pl. 8-24.

Describes, p. 36, and figures, pl. r9, fig. 2, a dragon fly from Solnhofen, which he compares with Libella grandis.

Schmidt, Wilhelm Ludwig Ewald. See Rathke, M. H.

Schreber, Johann Christian Daniel. Lithographia halensis exhibens lapides circa Halam Saxonvm reperivndos systematice digestos secvndvm classes et ordines genera et species cvm synonymis selectis et descriptionibvs speciervm. Prefatvs est 
Ioh. Ioach Langivs. I6 $6^{\circ}$ Halae. 1759. pp. 24 , So, pl. I.

Describes Entomolithus coleopteri from Rothenburg, pp. $5^{1-52 .}$

Schröter, Johann Samuel. Neue litteratur und beytrage zur kenntniss der naturgeschichte vorzüglich der conchylien und. fossilien. I er band. I6 . Leipzig. I 734 . p. (S), 550, (30), pl. 3 .

$\checkmark$. Ueber einige merkwürdige versteinerungen. A. Von versteinten insecten, 410-413, pl. 3 , fig. 10.

Schröter, J. S. Entomolithen, versteinte insecten. Schröter, Lithol. real-u. verbal-lex., 2 : 93-100. $\mathrm{S}^{\circ}$. Frankfurt. I779.

A compilation from the writings of the older authors.

Schröter, J.S. Inseckten, entomolithen. Schröter, Lithol. real-u. verbal-lex., 3:72-75. 8०. Frankfurt. 17 So.

General remarks of no present value.

Schweigger, August Friedrich. Beobachtungen auf naturhistorischen reisen; anatomisch-physiologische untersuchungen über corallen; nebst einem anhange, bemerkungen über den bernstein enthaltend. $4^{\circ}$. Berlin. 1819. pp. 8, I 28, (4), pl. 8, tab. I 2.

The Bemerkungen über den bernstein occupy pp. 101-127 and pl. 8, and contain in foot-notes extended descriptions of a few insects, figured carefully on the plate, but part at least of which have since been recognized as copal insects.

Scrope, George Poulett. The geology and extinct volcanoes of central France. 2 d ed. $8^{\circ}$. London. 1858. pp. 17, 258 , pl. 17.

Discusses, pp. 10-13, the indusial limestones of France, which he records at the following localities: hills of Gergovia above Romagnat, at the Puys Giron, de Jussat, de la Serre, de Mouton, de Dallet, at Mont Chagny, Mont Jughat, and les Côtes near Clermont; at Davayat near Riom; at Aigueperse, Gaunat, Mayet d'école, St. Gerard le Puy, between Jaligny and la Palisse, at Mont Barraud, etc. First edition not seen.

Scudder, Samuel Hubbard. On the devonian insects of New Brunswick. $8^{\circ}$. [Fredericton, 1865.] I p. Bailey, Obs. geol. southern N. Brumsu. 8o. Fredericton. I865. pp. I 40-I 41 . 1865 .

Amer. journ. sc., (2), 39:357-358. 80. N. Haven Ca.
$\mathrm{I} 865$.

Can. nat. geol., n. s., 2 : 234-236. 8o. Montreal.

Trans. entom. soc. Lond., (3), 2, proc. II7-II8. $8^{\circ}$

London. I866.

Short statement of the probable affinities of the oldest known insects, several species of which are distinguished.

Scudder, S. H. On the fossil insects from Illinois, the Miamia and Hemeristia. Amer. journ. sc., (2), 40:269-27 I. 80. N. Haven. I865.

Discussion of the affinities of two carboniferous insects, previously described by Dana.

Scudder, S. H. [Remarks on some fossil insects from the carboniferous formation of Illinois and from the devonian rocks of New Brunswick.] Proc. Bost. soc, nat. hist., I0: 95-96. $8^{\circ}$. Boston. 1865.

Merely an abstract of the two preceding papers.

Scudder, S. H. An inquiry into the zoological relations of the first-discovered traces of fossil neuropterous insects in North America; with remarks on the difference in structure in the wings of living Neuroptera. 4\%. [Boston.] I866. pp. 20, pl. Mcm. Bost. soc. nat. hist., I, I 73-192, pl.6. $4^{\circ}$. Boston. I 866.

Full treatment of the structure and relationship of Miamia and Hemeristia, which are referred to separate families, distinct from recent tvpes. The wing structure of the modern families is also systematically reviewed.
Scudder, S. H. Results of an examination of a small collection of fossil insects obtained by Prof. William Denton in the tertiary beds of Green River, Colorado. Proc. Bost. soc. nat. hist., II, I I 7-I IS. So. Boston. IS67.

The same; with slight additions. Hollister, Mines of Colorado, pp. $3^{\mathrm{So}} 3^{8} 3 . \quad$ I $2^{\circ}$. Springfield. IS67.

A bare statement of the relations of the insects. An abstract occurs in Amer. nat., i: $56.88^{\circ}$. Salem. ${ }_{1867 .}$

Scudder, S. H. On Mormolucoides articulatus. Proc. Bost. soc. nat. hist., I I : I 40 . So. Boston. IS67. Considers this triassic species to be a coleopterous larva.

Scudder, S. H. [Notice of fossil insects from the devonian rocks of New Brunswick and on $\mathrm{Ha}_{2}$ plophlebium Barnesii.] Proc. Bost. soc.nat.hist., I I : I 50-I 5I. 8\%. Boston. I 867.

Amer. nat., I : $445-446$. So. Salem. I 867 .

Refers the devonian insects to new families of Neuroptera and the carboniferous Haplophlebium probably to the Ephemeridae.

Scudder, S. H. The insects of ancient America. Amer. nat., I, 625-631, pl. I6. 80. Salem. IS68.

A popular account of those then known.

Scudder, S. H. [Remarks on two new fossil insects from the carboniferous formation in America.] Proc. Bost. soc. nat. hist., I I : 401-403. 80. Boston: I 868.

Scudder, Entom. notes, I : 7-9. 80. Boston. 1868 . Amer. journ.sc., (2), 46:419-421. 80. New Haven. I 868.

Describes Megathentomum pustulatum and Archegogryllus priscus. Abstract in A mer. nat., 2 : 390. 80. Salem. IS69.

Scudder, S. H. Entomological notes. I. So. [Boston. I868.] pp. II.

Reprints the preceding paper, with others.

Scudder, S. H. The fossil insects of North America. Geol. mag., 5: 1 72-177, 216-222. $8^{\circ}$. London. I868.

A review of the 87 species then known and of their geological relations. Abstracts will be found in the Amer. nat., $1: 557$. $8^{\circ}$. Salem. 1867 ; - Can. nat., (2), 3 : 293-294. $8^{\circ}$. M on treal. 1868 ; - Quart. journ. sc., 5 : 409. 8\%. Lond.
and Pop. sc. rev., $7: 318-319.80$. London. 1868.

Scudder, S. H. Descriptions of fossil insects, found on Mazon Creek and near Morris, Grundy co. Illinois. Worthen, Geol. surv. Ill., 3 : 566-572, figs. I-IO. 8०. [Springfield ?] I868.

Describes nine new carboniferous insects, mostly Neuroptera. It is also marked as a Supplement to Descriptions of articulates.

Scudder, S. H. On the fossil inyriopods of the coal formations of Nova Scotia and England [abstract.] Quart. journ. gcol. soc. Lond., 25, i: 44I. 8\%. London. I869.

Scudder, S. H. [Fossil insects found at the petrified fish-cut, Green River.] Hayden, sun fict. Rocky mount. scen., p. 98. $4^{\circ}$. New York. I870. Mentions in general terms the affinities of an ant and a fly.

Scudaer, S. H. Description d'un nouveau papillon fossile (Satyrites Reynesii) trouvé à Aix en Provence. $8^{\circ}$. Paris. I872. pp. 7, pl. I. R'ev. mag. zool., I 87 I-72: 66-72, pl. 7 .

EXTRACT : Description of a new fossil butterfly (Satyrites Reynesii) found at Aix in Provence. $8^{\circ}$. London. 1872. pp. 2, pl. I. Geol. mag., 9: 532-533, pl. 13 , figs. 2,3 .

Also entitled on cover: On a new fossil butterfly. The English trans?ation is by the editor. The species is from the tertiary.

Scudder, S. H. Fossil insects from the Rocky Mountains. $8^{\circ}$. Salem. 1872 . pp. 4. Amer. nat, $6: 665-668$. 80. Salem. I872.

A general notice of a collection of insects made by Richardson in the tertiary Green River deposits of Wyoming. Noticed in Trans. ent. soc. Lond., (2), 1874: 47-43. $8^{\circ}$. London. 1874 . 
Scudder, S. H. On the carboniferous myriapods preserved in the sigillarian stumps of Nova Scotia. Mem. Bost. soc. nat. hist., $2: 231-239.4^{\circ}$. Boston. 1873 .

Describes two genera and several species besides the Xylobius sigillariae of Dawson. Abstract in Amer. journ. sc., (3), 6: 225-226. 8०. N. Haven. 1873 .

Scudder, S. H. [On an English fossil insect described as lepidopterous.] Proc. Bost. soc. nat. hist., I6: I 12. 80. Boston. I874.

Considers Palaeontina oolitica Butler as homopterous rather than lepidopterous. See also Butler, A. G.

Scudder, S. H. Two new fossil cockroaches from the carboniferous of Cape Breton. Can. nat., (n. s.), 7 : 271-272, figs. I-2. So. Montreal. 1874.

Describes Blattina Heeri and B. bretonensis.

Scudder, S. H. The tertiary Physopoda of Colorado. 80. Washington. 1875. pp. 3. Bull. U.S. geol. geogr. surv. terr., 2 : $22 \mathrm{I}-223.8^{\circ}$. Washington. 1875 .

Describes one genus and three species.

Scudaer, S. H. Fossil butterflies. Mem. Amer. assoc. adv. sc., I. $4^{0}$. Salem. 1875. pp. 12, 99, pl. 3 .

Describes in detail the generic and specific characters of the five known species, besides four new ones, all from European tertiaries. After an historical introduction there are sections on their geological relations, the probable food plants of their caterpillars, the present distribution of their nearest allies, and the fossils believed to be erroneously referred to butterflies. More or less extended abstracts will be found in Arch. sc. phys. nat., n. s., 55: 102-103; 57 : 91-92. 80. Genève. 1876;Newes jahrb. miner., 1877: 445-447. 80. Stuttgart. 1877 ; A mer. journ. sc., (3), $11: 74-75.8^{\circ}$. N. Haven. $187^{\circ} ;-A$ mer. A mer. journ. sc., (3), 1r: 74-75. 80. N. Haven. $1876 ;-A$ mer. J. A.; and Lefebvre, A.

Scudder, S. H. Remarks on some remains of insects occurring in carboniferous shale at Cape Breton. Proc. Bost. soc. nat. hist., 18: 11 3-114. 80. Boston. 1875 .

Scudder, Ent. notes, $5: 2-3$. 80. Boston. I876.

Notices the discovery of cockroach wings and the larva of a dragon-fly at Sidney.

Scudder, S. H. Supplementary note on fossil myriapods. $4^{\circ}$. Boston. I878. p. I, figs. $M e m$. Bost. soc. nat. hist., 2 : $56 \mathrm{I}-562$, figs. $4^{\circ}$. Boston. 1878 .

Description of figures of the different species, omitted from a former paper.

Scudder, S. H. Fossil Orthoptera from the Rocky Mountain tertiaries. Bull. U.S. geol. geogr. surv. terr., ser. $2: 447-449.8^{\circ}$. Washington. 1876.

Describes a Labidura and a Homoeogamia.

Scudaer, S. H. [Lettre dे M. de Selys-Longchamps.] Compt. rend. soc. ent. Belg̈., (2), no. $2 \mathrm{I}$, p. 2. $8^{\circ}$. Bruxelles. 1876 .

Ann. soc. ent. Belg., 19, compt. rend., 2. 80. Bruxelles. 1876 .

Expressing an opinion against the lepidopterous character of Breyeria. Translation by de Selys.

Scudder, S. H. New and interesting insects from the carboniferous of Cape Breton. $8^{\circ}$. Salem. 1876. pp. 2, figs. Proc. Amer. assoc. adv. sc., 24 : B, I 10-1 I I, figs. I-2. 80. Salem. 1876.

Description of the cockroach and larval dragon-fly mentioned in a preceding paper.

Scudder, S. H. The same. $8^{\circ}$. Montreal. 1876 . pp. 2, figs. Can. nat., (n.s.), $8: 88-90$, figs. 1-2. $8^{\circ}$. Montreal. 1876 .

Scudder, S. H. Fossil Coleoptera from the Rocky Mountain tertiaries. Bull. U. S. geol. geogr. surv. terr., $2: 78-87.8^{\circ}$. Washington. I876.

Describes thirty species mostly from Green River, Wyoming, and White River, Colorado.
Scudder, S. H. Brief synopsisis of the North American earwigs, with an appentix ' on the fossil species. Bull. U.S. geol. geogr. surv. terr., 3 . 8o. Washington. 1876.

The Note on the fossil species occurs on pp. 259-260, discusses one species already known from the tertiary beds of Florissant, and describes another from the same locality.

Scudder, S. H. Critical and historical notes on Forficulariae; including descriptions of new generic forms and an alphabetical synonymic list of the described species. Proc. Bost. soc. nat. hist., 18 : 2S $7-33^{2}$. $8^{\circ}$. Boston. 1876 .

Scudder, Ent. notes, 5: 27-72. 8०. Boston. 1876 . Includes the fossil forms, of which eight species are enumerated.

Scudder, S. H. Entomological notes, V. $8^{\circ}$. Boston. I876. pp. 72.

Reprints, with other matter, the last-mentioned paper and Remarks on some ... insects ... at Cape Breton.

Scudder, S. H. Fossil palaeozoic insects, with a list of described American insects from the carboniferous formation. Geol. mag., (n.s.), dec. 2, vol. 3, $p p$. 519-520. 8. London. 1876.

Gives a list of thirty species. Entitled in table On fossil in. sects from the coal measures.

Scudder, S. H. On the close affiliation of the insects of Europe and America in the carboniferous epoch. Proc. Bost. soc. nat. hist., 18: 358-359. $8^{\circ}$. Boston. 1876.

As intimately related as now.

Scudder, S. H. Note on fossil ants from South Park, Colorado. Amer. nat., 11 : 191. 80. Salem. 1877 .

Scudder, S. H. The insects of the tertiary beds at Quesnel (British Columbia). 80. [Montreal. 1877.] pp. 15. Rep. progr. geol. surv. Can., 1875-'76: 266-280. 8०. [Montreal.] 1877 .

Describes twenty-four species of various orders.

TrANSLATion: Les insectes des lits tertiaires de Quesnel. Rapp. opér. expl. géol. Can., I875-'76: 294-310. 80. [Montreal.] 1877.

Scudder, S. H. On the first discovered traces of fossil insects in the American tertiaries. Bull.U.S. geol. geogr. surv. terr., 3:741-762. 80. Washington. 1877 .

Describes the insects obtained by Denton in the White River beds, Colorado. Thirty-three species, mostly Diptera, are described and others enumerated.

Scudder, S. H. Description of two species of Carabidae found in the interglacial deposits of Scarboro' Heights, near Toronto, Canada. Bull. U.S. geol. geogr. surv. terr., $3: 763-764$. $8^{\circ}$. Washington. 1877 .

Referred to Loxandrus and Loricera.

Scudder, S. H. Note on the wing of a cockroach from the carboniferous formation of Pittston, Penn. Proc. Bost. soc. nat. hist., 19: 238-239. $8^{\circ}$. Boston. 1878 .

Scudder, Entom. notes, 6:35-36. 8. Boston. 1878 . Describes Blattina fascigera.

Scudder, S. H. An insect wing of extreme simplicity from the coal formation. Proc. Bost. soc. nat. hist., 19: 248-249. 8०. Boston. 1878 .

Scudder, Entom. notes, $6: 37-3^{8}$. $8^{\circ}$. Boston. 1878 . Describes Euephemerites primordialis.

Scudder, S. H. A carboniferous termes from Illinois. Proc. Bost. soc. nat. hist., 19:300-301. 80 . Boston. 1878 .

Scudder, Entom. notes, 6:54-55. 80. Boston. 1878 .

Describes Termes contusus. 
Scudder, S. H. An account of some insects of unusual interest from the tertiary rocks of Colorado and IVyoming. Bull.U.S. geol. geogr. surv. terr., 4 : 519-5+3. So. Washington. 1878 .

Describes ten insects of different orders, among them a remarkabiy neriect butterfly, Prodryas Persephone, and eggs and egg clusters of a gigantic sialid, Corydalites fecundum.

Scudder, S. H. Adclitions to the insect fauna of the tertiary beds at Quesnel (British Columbia). 80. [Montreal. 1878.] pp. 8. Rep.progr. geol. surv. Can., is $76-77: 457-464$. So. [Montreal.] is 7 S.

Describes six more species of different groups.

Translation: Additions à la faune entomologique des lits tertiaires de Quesnel, Colombie britannique. Rapp. ofér.comm géol. Can., is $76-77$ : 514-522. So. [Montreal.] I 73 S.

Scudder, S. H. Entomological notes, VI. $8^{\circ}$, Boston. IS78. pp. 55, pl.

Reprints, among other matter, three short papers already mentioned.

Scudder, S. H. The fossil insects of the Green River shales. Bull. U.S. geol. geogr. surv. terr., 4: $747-776$. $8^{\circ}$. Washington. 1878 .

Describes fiftr-five species of different groups with notes on seventeen others.

Scudder, S. H. The early types of insects; or the origin and sequence of insect life in palaeozoic times. Mem. Bost. soc. nat. hist., $3: 1_{3}-21.4^{0}$. Boston. 1879 .

A general review of paleozoic insects, attempting to show "that the laws of succession of the insect tribes are quite simila to those which have long been known to hold in other groups of the animal kingdom; and that the facts are, in the main, such as the theory of descent demands." The general conclusions are summarized under twelve heads. It is noticed and criticised by de Borre in Compt. rend. soc. ent. Belg., (2), no. 65, p. I1. 80 . Bruxelles. 1879 .

Translation: Les premiers types d'insectes; origine et ordre de succession des insectes dans la période paléozoique. Arch. sc. phys. nat., (3), 3: 353-371. 80. Genève. 1880.

The translation is by A. Humbert. Some notes, especially the bibiiographical, are onitted.

ABSTRACT: The early types of insects. Abstract of a paper read before the National academy of sciences, Nov. 5, 1878. Am. journ. sc. arts, (3), 17 : 72-74. $8^{\circ}$.. New Haven. 1879.

Science Nerws, 1 : 22-23. $80^{\circ}$. Salem. $\quad 1878$.

This contains the general conclusions.

Translation: Urtypen der insecten. Kosmos, 5 : 6I-62. 80. Leipzig. I879.

A translation of the abstract, with notes by the editor.

Scudder, S. H. The fossil insects collected in I 577 , by Mr. G. M. Dawson, in the interior of British Columbia. K'ep. progr. geol. surv. Can., I877-'78: B, 176-is6. So. Montreal. 1879 .

Describes sixteen species of different orders. Also published separately with half-title on cover: Insects from the tertiary beds of the Nicola and Similkameen rivers, British Columbia. 80. [Montreal. 1879.] pp. it.

Translation: Insectes fossiles recueillis en 1877 , par M. G. M. Dawson, dans l'intérieur de la Colombie-britannique. Rapp. opér. comm. géol.Can., 1877-'78: B, 2 II-223. So. [Montreal. IS79.]

Scudder, S. H. Palaeozoic cockroaches; a com plete revision of the species of both worlds, with an essay toward their classification. Mem. Bost. soc. nat. hist., 3: 23-134, pl. 2-6. $4^{\circ}$. Boston. I\$79.

The first attempt to classify any group of paleozoic insects of both worlds by characters drawn from the venation of the wing. Inre than sixty species (thirteen of them new) are described and figured; they are divided into two tribes and eleven genera, and separated as a whole from modern cockrnaches under the and separated as a whole from modern cockrnache
name Palaeoblattariae. See also Geinitz, F. E.
Scudder, S. H. The insect basin of Florissant. Psyche, 3: 77. So. Cambridge. IS8O.

Scudder, S. H. The devonian insects of New Brunswick. $4^{\circ}$. Boston. I8So. pp. 4I, pl. I. Anniv. mem. Bost. soc. nat. hist., scient. papers, art. (3). $4^{\circ}$. Boston. 1880 [I88I]. pp. 4I, pl. I.

Detailed descriptions of six species, the oldest in the world, with a study of their affinities. A jurassic may-fly is also described and the general conclusions summarized at the close.

EXTRACT: Relations of devonian insects to later and existing types. Amer. journ. sc. arts, (3), 2 I : I I I-I I 7. 80. New Haven. I 88I.

Ann. mag. nat. hist., (5), $7: 255^{-261}$. 80. London. I88r.

Gives the general conclusions in full.

A BSTRACT: The devonian insects. Amer. nat., 14: $905-907$. 80 . Philadelphia. ISSO.

ABSTRACT: The devonian insects of New Brunswick. Science, 1 : 292-293. $4^{\circ}$. New York. ISSo.

The above give the general conclusions somewhat condensed. More or less extended abstracts or notices wiil also be found in A rch. sc. phys. nat., (3), 5, 291-293 (by A. Humbert). 80. Genève. I881:-Bull. soc. ent. ital., 12: 279-280. 80. Firenze. 1881;-Naturforscher, 1881: 141-143. $4^{\circ}$. Berlin. 1881; - Nation, 32: whole or part in Nature, 23: $483-484$ (by H. A. Hagen). $4^{\circ}$. London. 1881; - Bull. mus. comp. zool., 8: no. 14, pp. 275-284 (by the same). 80. Cambridge. 1881; - and Nature, $23: 507$ (by A. E. Eaton). $4^{\circ}$. London. 1881.

Scudder, S. H. The structure and affinities of Euphoberia Meek and Worthen, a genus of carboniferous Myriapoda. Amer. journ. sc. arts, (3), 21: 182-186. 80. New Haven. I88 I.

Points out the distinction between the carboniferous and modern diplopodous myriapods, and proposes a distinct suborder, Archipolypoda, for the former.

Scudder, S. H. Some recent publications on fossil insects. Psyche, $3: 13^{8}$. 80. Cambridge. I 880. A review of Goss's papers.

Scudder, S. H. White ants in the American tertiaries. Harv. univ. bull., 2 : 219. $4^{\circ}$. Cambridge. $188 \mathrm{r}$.

Note on the relation of the six species from Florissant to those of other tertiary deposits; they indicate a warm climate.

Scudder, S. H. Two new British carboniferous insects, with remarks on those already known. Giol. mag, (2), 8 : 293-300, fig. 80. London. I 88r.

The only two hexapods hitherto known (excepting a cockroach) are Neuroptera and not Orthoptera as had been recently maintained. Two new species are described, A rchaeoptilus ingens, the largest paleozoic insect known, and Brodia priscotincta, rethe largest paleozoic insect known, and Brodia priscotincta, remarkable for the preservation of the colored bands of the wing. title New carboniferous insects.

ABSTRACT: Upon the carboniferous insects of Great Britain. Harv. univ. bull., $2: 175.4^{\circ}$. Cambridge. I $88 \mathrm{I}$.

Scudder, S. H. [Exhibition of a carboniferous cockroach.] Psyche, 3: 186. $4^{\circ}$. Cambridge. 1881. Showing difference in venation of opposite wings.

Scudder, S. H. The tertiary lake basin at Florissant, Colorado, between South and Hayden Parks. Bull. geol. geogr. surv. terr., 6 : 279-300, map. 80 . Washington. I881.

The first half is descriptive of the locality and its geology; the paleontological portion is mainly devoted to insects and plants, palch a running systematic review is given. The conclusion of which a running systematic review is given. The conclusion is reached that the beds, the most prolific of insects in the world, "belong in or near the oligocene." An abstract will be found in read before the Buston natural history society. See Proc. Bost. soc. nat. hist., $21: 81$. 80 . Boston. $188 \mathrm{r}$.

Scudder, S. H. [Exhibition of carboniferous centipedes.] Proc. Bost. soc. nat. hist., 2 I : 82. So. Boston. I $88 \pi$. 
Scudder, S. H. Remarks on remarkable carboniferous millipedes. Proc. Bost. soc. nat. hist., 2 I : 122. So. Boston. I $\$ 8 I$.

They form a distinct suborder.

Scudder, S. H. On Lithosialis bohemica. Proc. Bost. soc. nat. hist., $21: 167$. 80. Boston. 1981.

Reviews Novák's description of Gryljacris bohemica, showing that it is neuropterous not orthopterous.

Scudder, S. H. Fossil spiders. Harv. univ. bull, $2: 302-303$. So. Cambridge. I $8 S 2$.

Reviews the arachnid fauna of Florissant, Col., and shows its relation to the forms of the European tertiaries.

Scudder, S. H. See also Brodie, P. B.; de Borre, A. P. ; Dawson, J. IV. ; Fontaine, IV. M. and White, J. C. ; Hagen, H. A. ; Lefebvre, A.; Packard, A. S.; Peale, A. C. ; and White, C. A. de Selys-Longchamps, Michel Edmond. See de Borre, A. P. ; Scudder, S. H. ; and de SelysLongchamps, M. E., et Hagen, H. A.

de Selys-Longchamps, Michel Edmond, et Hagen, Hermann August. Revue des odonates ou libellules d'Europe. S\%. Bruxelles, etc. I850. pp. 22, 40S, pl. 1 I, tableaux 6.

Contains, pp. 356-364, Énumération des odonates fossiles d'Europe, by Dr. Hagen with a few notes by Baron de Selys; and pp. $365-368$ Note sur l'énumération des odonates fossile d'Europe, by de Selys. In the former 39 species are enumerated with synonymy and brief notes; in the latter they are discussed by formations and the conclusion reached that Aeschnidae preceded the Agrionidae and Libellulidae.

Sendelius, Nathaniel. Verschiedene erinnerungen von dem succino prussico. Contin. gelehrt. Preussen, I 725, quart. 2, no. 3. 80. Thorn. I725.

Not seen. Title furnished by Dr. Hagen.

Sendelius, N. Nathanaelis Sendelii ... electrologiae per varia tentamina historica ac physica continuandae missus primus De perfectione succinorum operibus naturae et artis promota testimoniisque rationis et experientiae demonstrata. $4^{\circ}$. Elbingae. I725. pp. 56 .

Reviewed in Acta erud., i725: 374-376. $4^{\circ}$. Lipsiae. 1725.

Sendelius, N. The same. Missus secundus, De mollitie succinorum et inde emergentibus contentis variis animalibus, vegetabilibus, mineralibus atque aquosis. 40. Elbingae. I726. pp. 64

Sendelius, N. The same. Missus tertius, De prosapia succinorum et eorum variis affectionibus, vi electrica, colore, odore, sapore. $4^{\circ}$. Elbingae. [1728.] pp. 56.

These titles are furnished by Dr. Hagen, who also quotes, but unverified by him, the English translation in Acta germ., 1743 : $340-353,360-366,389-405$. $4^{\circ}$. London. 1743 .

Sendelius, N. Historia succinorum corpora aliena involventium et naturae opere pictorum et caelatorum ex regiis Augustorum cimeliis Dresdae conditis aeri insculptorum conscripta. fo. Lipsiae. 1742. pp. Io, 328, tab. I3.

A large part of the book and nearly seven of the plates are given up to insects, but amber and copal insects are, as is weil given up to insects, but amber and copal hsects are, as is well
known, not distinguished, and the book has therefore far less value and interest than it otherwise would possess.

Reviewed in Nova acta erud., 1743: 49-56. $4^{5}$ Leipzig. 1743 (the insects mentioned on pp. 50-52); also, according to Boehmer (references unverified) in Nouv. bibl. germ., $3: 1 ; 6: 33_{5}$; Commerc. litt. med. sc. nat., 23 : 177. $4^{\circ}$. Norimbergiae. 1742; Leipz. gel. zeit., 1742: 414.8 . Leipzig. 1742; Zuverl. nachr. Leipz. gel. zeit., 1742: 414. $8^{\circ}$. Leipzig.
gegenzw. zust. wiss., $34: 77^{8}$. 8. Leipzig.

See also Guerin-Meneville, F. E.

Sendelius, N. De succino indico, ad virum nobilissimum atque experientissimum dominum Johannem Philippum Breynium epistola, prodromi loco electrologiae suae propediem edendae scripta.
Brevn, Melon. petref. mont. Carmel, 35-48. $4^{\circ}$. Lipsiae. 1722 .

Entitled on Breyn's title-page : De pseudo-succino, quod paucos ante annos ex Africa in belgium deferri coepit. It evidently refers to copal, and mentions, p. $4^{\circ}$, the occurrence of insects "nostris similia." Noticed in Bibl. germ., $5: 12$ I.

de Serres, Pierre Marcel Toussaint. Suite du Mémoire sur les terrains d'eau douce, ainsi que sur les animaux et les plantes qui vivent alternativement dans les eaux douces et dans les eaux salées. Foutrn. phys., S7 : I6I-I7S. 4\%. Paris. ISIS.

Refers, p. 173 , to impressions of insects, principally of aptera and among them iulids, from the tertiaries of Castelnaud, France.

de Serres, P. M. T. Notice sur les cavernes à ossemens fossiles des carrières de calcaire grossier, situées aux environs de Lunel Vieil, dans le département de l'Hérault. Mém. soc. linn. Paris, $5: 44^{2-464}$. So. Paris. $1 \$ 27$.

$\$ \mathrm{~V}$. Insectes, p. 457 , gives a very brief account of the remains of Coleoptera found in the cavern.

de Serres, P. M. T. Note sur les arachnides et les insectes fossiles, et spécialement sur ceux des terrains d'eau douce. Ann. sc. nat., 15:98-108. 80. Paris. 1828 .

Ferr, Bull. sc. nat., I 5 : I8I-189. So. Paris. I828.

An extract from the next work, pp. 207-233, published in advance.

Translation: Bemerkung über die fossilen arachniden und insecten, besonders über diejenigen, welche in der süsswasserformation vorkommen. Thon, Entom. archiv., 2, ii : 74-77. 4\%. Jena. 1829.

A BSTRACT : Notiz über fossile arachniden und insecten, und besonders über diejenigen, welche in den niederschlägen des süssen wassers gefunden werden. Froriep, Notiz. geb. nat.heilk., $22: 337-342.44^{\circ}$. Erfurt. I 828.

de Serres, P. M. T. Géognosie des terrains tertiaires, ou Tableau des principaux animaux invertébrés des terrains marins tertiaires, du midi de la France, etc. So. Montpellier et Paris. 1829. pp. 92, 277. "tableaux" 3, pl. 6.

Livre 4 : Des arachnides et insectes fossiles, et spécialement de ceux des terrains d'eau douce du bassin tertiaire d'Aix occupies pp. 206-258, and includes a list of nearly 80 genera of Aix insects, besides, pp. 254-258, a Tableau général des araclinides et des insectes fossiles, d'après l'ordre de formations géologiques, in which 105 genera are specified and 226 species enumerated.

de Serres, P. M. T. Notes géologiques sur la Provence. Actes soc. linn. Bord., $13: \mathrm{I}-82.80$. Bordeaux. 1843 .

Contains a list of insects of Aix, pp. 34-44.

de Serres, P. M. T. Note additionelle à la Notice géologique sur la Provence. Actes soc. linn. Bord., I 3 : 83-91. 80. Bordeaux. 1843 .

Continuation of preceding, with nothing on insects.

de Serres, P. M. T. Deuxième note additionelle au Mémoire géologique ... sur la Provence. Actes soc. linn. Bord., I3 : I70-172. So. Bordeaux. I843.

Page 172 contains a Note relative au lépidoptère figuré au no. 4; but the butterfly, Neorinopis sepulta, appears to have been published in a limited edition only, as the two or three copies I have examined do not contain it. Two years later Serres mentions its publication.

de Serres, P. M. T. Sur les fossiles du bassin d'Aix (Bouches du Rhône.) Ann. sc. nat., (3), zool., 4 : 249-256. 8o. Paris. 1845 . .

Pp. 251-254 are mostly given to combating the arguments drawn from the presence of Cyllo sepulta in favor of the equatorial nature of the ancient climate of Aix.

de Serres, P. M. T. See Pictet de la Rive. F. .T.

Signoret, Victor. See Millière, P. 
Sismonda, Eugenio. Matériaux pour servir à la paléontologie du terrain tertiaire du Piémont. Mem. accad. sc. Torino, (2), 22 : 391-47 I, pl. I-33. $4^{\circ}$. Torino. 1865 .

Refers, p. 470, to the occurrence of the larva of Libellula Doris in the upper miocene beds of Guarene; it is figured, pl. 17, fig. 6 .

Sivers, Henricus Jacobus. Cvriosorvm niendorpiensivm. $4^{\circ}$. Lvbecae. $173^{2}$.

Specimen IV sistens svccinorvm descriptionem occupies pp. 65-81, with a plate. Reference furnished by Dr. Hagen.

Smith, Edward. On the stream works of Pentowan. Trans. geol. soc. Lond., 4: 404-409. 4\%. London. 1817 .

Records, p. 407, the "wings of coleopterous insects" at a depth of forty-six feet from the surface of the ground below layers of peat and sea mud in a section at Pentowan, Cornwall, half a mile from the coast.

Smith, E. J. A'Court. Discovery of remains of plants and insects. Nature, I I : 88. $4^{\circ}$. London. I874.

Notice of fossil insects in the tertiary beds at Gurnet Bay, Isle of Wight.

Smith, Frederick. See Evans, C. E.

Smith, Sidney Irving. Notice of a fossil insect from the carboniferous formation of Indiana. (Brief contributions to zoology from the museum of $Y$ ale College, no. ix.) $8^{\circ}$. [New Haven. 1871.] pp. 3. Amer. journ. sc., (3), I : 44-46. $8^{\circ}$. New Haven. 1871 .

Describes Paolia vetusta, a neuropterous insect.

Snellen van Vollenhoven, Samuel Constant. Eugereon Boeckingi. Verslag alg. vergad. nederl. entom. vereen., 22: 13. 80. 'sGravenhage. 1867. Tij.
$\mathbf{1 8 6 8 .}$.

Tijdschr. $v$. entom., (2), $3:$ I3. 8o. 'sGravenhage.

Denies that there are any purely hemipterous characteristics in Eugereon; but regards it as simply neuropterous.

Spener, Christian Maximilian. See Vallisnieri, A.

Stainton, Henry Tibbats. See Bolton, J.

Stein, Johann Philipp Emil Friedrich. Drei merkwürdige bernstein-insecten. Mitth. münch. entom. ver., I : 28-30. 80. München. 1877.

Not seen. Describes two Coleoptera and one Hymenopteron.

Steinbeck, A. Ueber die bernsteingewinnung bei Brandenburg an der Havel. I 20 . Brandenburg. I841. Neue not. natur- heilk., I4: 257-263. $4^{\circ}$. Weimar. 1840 .

Separate publication not seen. Notices, p. 262, collections of amber insects made by Schirrmeister and himself, showing the fauna to be the same as that of the amber of the Baltic coast.

An abstract will be found in Newes jahrb. mineral., 1844: 12 I-122. 80. Stuttgart. 1844 .

Sternberg, Kasper. Vortrag des präsidenten ... in der allgemeinen versammlung des böhm. museums am I4 April, I835. Verh. gesellsch. vaterl. mus. Böhm., 1835: 12-30. I60. Prag. 1835 .

Contains, pp. 23-24, a history of the discovery of the scorpion described in same volume by Corda.

Sternberg, K. Insektengänge im blatte der Flabellaria borassifolia. Verhandl. gesellsch. vaterl. mus. Böhm., I836: 34-35, pl. I, figs. 3-4. I60. Prag. 1836.

Showing mines of an insect "ganz so, wie es die larven der blattschaben in dem parenchym der blätter jetzweltlicher pflanzen hinterlassen."

Sterzel, J. T. Ueber Palaeojulus dyadicus. Nenes jahrb. miner., 1878:729-731. So. Stuttgart. 1878.

Considers the fossil described by Geinitz as a myriapod to be a fern-leaf, of a species of Scolecopteris.
Sterzel, J. T. Ueber Palaeojulus dyadicus Geinitz und Scolecopteris elegans Zenker. Zeitschr. deutsch. geol. gesellsch., 30 : 417-426, taf. 19. 80 . Berlin. 1878 .

Mainly devoted to showing that no animal remains have been found which possess the characters assigned to Palaeojulus dyadicus; but this so-called myriapod is the half of a leaf of Scolecopteris elegans, a fern.

Sterzel, J. T. Ueber Scolecopteris elegans Zenker und andere fossile reste aus dem hornstein von Altendorf bei Chemnitz. Zeitschr. deutsch. geol. gesellsch., 32 : 1-18, taf. 1-2. 80. Berlin. I880.

Has a brief reference to Palaeojulus dyadicus on pp. I-2.

Sterzel, J. T. Ueber zwei neue insektenarten aus dem karbon von Lugau. Ber. naturw, gesellsch. Chemnitz, $7: 271-276, p l$. 8o. Chemnitz. I881.

Describes and figures Blattina (Etoblattina) lanceolata and Termes (Mixotermes?) lugauensis.

Stizenberger, Ernst. Uebersicht der versteinerungen des grossherzogthums Baden. 80. Freiburg i. B. I851. pp. I 44 .

A list of Oeningen insects compiled from the first two parts of Heer's work occurs on pp. 95-10r with references to collections ; and on p. Irg a reference to eggs and larvae of beetles and flies from the alluvium of the Rhine.

Stoehr, Emilio. Notizie preliminari su le piante ed insetti fossili della formazione solffifera in Sicilia. Bull. com. geol. Ital., I875, 284-287. 80. Roma. I875.

The insects from Girgenti are determined by Dr. von Heyden, p. 286, as larvae of Libellula Doris Heer and L. Eurynome Heer, the former in great quantities; both are Oeningen species.

Strickland, Hugh Edwin. On the occurrence of a fossil dragon-fly in the lias of Warwickshire. Mag. nat. hist., (n. s.), 4: 301-302, figs. II-13. 80. London. I840.

Description of Aeshna liassina.

Strickland, H. E. On the results of recent researches into the fossil insects of the secondary formations of Britain. Rep. Brit. assoc. adv. sc., I845, notices, 58. 80. London. I846.

A general account of what had been published by Brodie, with a few general deductions.

Swagerman, Everard Pieter. Waarneeming omtrent de insekten, welken in de gomlak gevonden worden. Verhand.zeeuwsch. genootsch. wetensch. Vliss., 7, ii : 227-258. pl. 8o. Middelburg. I780.

Swinton, A. H. Notes on certain fossil Orthoptera claiming affinity with the genus Gryllacris. 80. [London. I874.] pp. 5. pl. Geol. mag., (2), I : 337$34 \mathrm{I}, \mathrm{pl}$. 14. 80. London. 1874 .

Entitled on cover of separate On fossil Orthoptera. Claims to show that the carboniferous Corydalis Brongniarti is a Gryllacris, and discusses the tertiary species which have been referred to Gryllacris.

Swinton, A. H. Insect variety : its propagation and distribution; treating of the odours, dances, colours, and music in all grasshoppers, cicadae and moths ; beetles, leaf-insects, bees, and butterflies; bugs, flies, and ephemerae ; and exhibiting the bearing of the science of entomology on geology. $8^{\circ}$. London, etc. [1880.] pp. 10, 326, pl. 7 .

Notices the stridulation of extinct insects, pp. 163-164; and reviews the strata containing insect remains in a discursive manner, pp. 260-271.

Swinton, A. H. A study of the variation of the small tortoise-shell butterfly (Vanessa urticae.) Hardw. science gossip, 1881 : 147-149, 176-179, figs. 88, 104, 105. 1. 80. London. 1881.

A study of the evolution and specialization of butterflies and moths, showing how the markings of the wings of fossil Lepidoptera harmonize with the systematic design found in recent doptera harmonize with the systematic design found in recent species; in figs. 104, ro5 on p. 177 he attempts restorations
Neorinopis sepulta and a tertiary Bombyx, both from Aix. 
T(ate), R(alph). See d'Eichwald, E.

Tate, Ralph, and Blake, J. F. The Yorkshire lias. $8^{\circ}$. London. 1876 . pp. 12, 475, 1 2, pl. 19, 4, map.

Class Insccta by J. F. Blake, p. 426, pl. 16 (pars). Figures without description a Buprestites and a Chauliodites.

Taylor, J. E. The geological antiquity of flowers and insects. Pop. science review, 17 (n. s., 2):36-52, figs. $8^{\circ}$. London. 1878 .

Points out "a broad parallelism between the appearances of the more differentiated types of the vegetable kingdom and the development or appearance of various orders of insects ;" and on pp. 43-44 gives an account of the general distribution of insects in geological times.

Taylor, Richard Cowling. Illustrations of antediluvian zoology. Articulated animals. Loud., Mag. nat. hist., $3: 36 \mathrm{I}$. 8०. London. 1830 .

Notices Coleoptera from Stonesfield slate, coal shale of Yorkshire, peat beds of Norfolk, Yorkshire and Lincolnshire coasts, Mount's bay in a submarine forest, and at the Danby coal pits, Yorkshire.

Thorell, T. On European spiders; part I. Review of the European genera of spiders, preceded by some observations on zoological nomenclature. $4^{\circ}$. Upsala. I869-70. pp. 24, 242.

Contains remarks on fossil spiders, pp. 220-233, in which the affinities of the described species are discussed, and some new genera are founded.

Troost, Gerard. Description of a variety of amber, and of a fossil substance supposed to be the nest of an insect discovered at Cape Sable, Magothy river, Ann-Arundel county, Maryland. Amer. journ. sc. arts, 3: 8-1 5. 80. New Haven. 1821.

Considers the nest found in a stratum of lignite, and which is described on pp. ro-11, to be "a lind of comb or nidus made by some insects around the twigs ... of a tree."

Translation : Bernstein mit gall-insekten nestern vorkommend in Maryland in Nord-Amerika nach dem Dr. Troost zu Baltimore, frei bearbeitet von Gilbert. Ann. phys., 70: 297-303. 80. Leipzig. 1822 .

Accompanied by foot-note, by Gilbert, and followed, pp. 303304, by a Zusatz zu diesem aufsatze by the same in which certain similar appearances in European amber are noted. Gilbert considers them gails.

TRANSLATION : Ueber das vorkommen des bernsteins zu Cap-Sable in Nordamerika. Fahrb. chem. phys., 4 (Fourn. chem. phys., 34): 434-439. I $6^{\circ}$. Nürnberg. 1822 .

The final notes are omitted and the phraseology slightly altered.

ABSTRACT : Vorkommen des bernsteins in NordAmerika. Arch.bergb. hüttenw., 6:416. 160. Berlin. 1823.

\section{Makes no reference to the "insect-nests."}

Translation : Beschreibung einer varietät von bernstein (amber) und eines fossils, wahrscheinlich des nestes eines insekts, entdeckt bei Cap Sable, am Magothy-fluss, in Ann-Arundel county, Maryland. Schrift. phys.-ökon. gesellsch. Königsb., II : 54-58. $4^{\circ}$. Königsberg. 1871 .

The translation, which is by $\mathrm{Dr}$. Hagen, omits only about a page of unimportant matter in the concluding notes. It is empodied in an article by Dr. Berendt, entitled Ueber eine von Dr. G. Troost in Baltimore im jahre 1821 im American-journal of science gegebene beschreibung eines bernstein-vorkommens bei Cap Sable in Maryland; and is preceded and followed by remarks of Dr. Berendt which, however, do not refer to the insectnests.

Troost, G. See also Eagen, H. A.

Unger, Franz. Ueber die pflanzen und insekten reste von Radoboj in Kroatien. Unger, Reise notizen, 1838: 26-33. 8\%. [Wien. i 840 ?]

Not seen; an abstract will be found in Neues jahrb. miner., $1840: 374-377$. 80 . Stuttgart. 1840 . Insects are mentioned on $p$.
377; there are no Coleoptera nor Lepidoptera; Diptera and Hymenoptera are most abundant; Neuroptera, Orthoptera and Hemiptera rarer. A single spider was found. The fauna is tropical rather than European.

The Reise notizen are referred to in no bibliographies. They appeared separately for 1838 and 1839 , and were probably extracts from some local paper. Cf. Newes jahrb. mineral., $1840: 726$.

Unger, F. Chloris protogaea. Beiträge zur flora der vorwelt. fo. Leipzig. Heft I, pp. 4, 4, I-I6, pl. $\mathrm{x}-5(1840)$; - heft $2-3$, pp. 5-24, I7-44, pl. 6-1 5 (I842); - heft $4-5$, pp. $45-92$, pl. I6-25 (1843); heft $6-7$, pp. 25-110, pl. 26-35 (1845); 二 heft 8-10, t. p., ded. pp. $93^{-1} 50$, pl. $3^{6-50}$ (1847).

Insects are figured on pl. $4,5, \mathrm{x}$ I, $14,15,22,28,40,44,45,48$. All are from Radoboj.

Unger, F. Fossile insecten. $4^{\circ}$. [Breslau.] I 841 . pp. I6, pl. 2. Acta acad. caes. Leop.-Carol., 19, ii : 4I 3-428, tab. 71-72. $4^{\circ}$. Vratislaviae et Bonnae. 1842 .

Describes and figures eight Diptera from the tertiary beds of Radoboj; a geological section is given on the first plate, and the larger part of the paper, pp. 415-424, is given to an account of the locality.

Unger, F. Die fossile flora von Szántó in Ungarn. Denkschr. kais. akad. wiss. Wien, math.-nat. cl., 30, i : 1-20, pl. I-5. 40. Wien. 1870 .

Describes, pp. 3-4, and figures, pl. I figs. 13-14, the elytron and wing of a beetle, Melolonthites parschlugiana.

Unger, F. See also Heer, O.

Ussher, W. A. E. Pleistocene geology of Cornwall ; part iv. Submerged forests and stream tin gravels. Geol. mag., (2), 6: 251-263. $8^{\circ}$. London. 1879 .

Refers in several places, on the authority of others, to the discovery of coleopterous remains in pleistocene deposits.

Ussher, W. A. E. The post-tertiary geology of Cornwall. 8o. Hertford. 1879. pp. (4), 59, pl. (I), figs.

Refers, pp. 30, 32, to the occurrence of elytra in alluvium and clay at different localities, on the authority of others.

Vaillant, Léon. Sur un geckotien de l'ambre jaune. Bull. soc. philom. Paris, 10:65-67. 80. Paris. I 873 .

Mentions, p. 67 , a couple of insects accompanying the reptile, afterwards more fully treated by Oustalet.

Valentini, Michael Bernhard. Museum museorum oder Vollständige scliau bühne aller materialien und specereyen etc. Zweyte edition. 3 v. fo. Franckfurt am Mayn. I7i4. Vol. I: 3 t. p., pp. (24), $520(16), 76,(4), 119 ;-$ vol. $2: 3$ t. p., pp. (18), 196, (4), 1 16 ; - vol. 3 : pp. (4), 218 , (12), plts., figs.

Also with the title: D. Valentini schau bühne oder Naturund materialien kammer, auch ostindianische send-schreiben und rapporten. Contains various references to insects in amber, original or quoted; see especrally i. p 516, ii. p. 60 , and ii. anhang, pp. 93, 99

Vallisnieri, Antonio. Istoria del cameleonte affricano, e di varj animali d' Italia. $4^{\circ}$. Venezia. I 7 I 5. pp. (8), 200, tav. 5, 8 .

Contains, pp. I8r-rgo, an Epistola to Vallisneri by Spener upon various fossils, including insects, which are mentioned from the rocks of Thüringen on pp. 186-187, and from amber on p. 187. In the latter he recounts as in his possession "muscas, culices, araneas, formicas volantes, scolopendras aliaque animalcula."

de Verneuil, Philippe Edouard Poulletier. See d'Archiac et de Verneuil, É.

Viquesnel, Auguste. Note sur les environs de Vichy, département de l'Allier. Bull. soc. géol. France, I4: $145^{-1} 55$. 80. Paris: I842.

Refers on p. $r 49$ to the cases of phryganids. 
Vogel, Rudolf Augustin. Practisches mineralsystem. Zweyte vermehrte und verbesserte ausgabe. So. Leipzig. I776. pp. (22), $5^{\mathrm{S} 2}$.

Not seen. The first edition was published in 1762 , and is said to contain reference to Ueningen insects.

Vogt, Karl. Lehrbuch der geologie und petrefactenkunde. Zum gebrauch bei vorlesungen und zum selbstunterrichte. Zweite vermehrte. und gänzlich umgearbeitete anflage. 2 v. 8o. Braunschweig. I' 54 . Vol. 1, pp. 29, 642, pl. 8, (6) ;-vol. 2, pp. 3I, 672 , pl. (2.)

Insects are meagrely treated, with two or three figures copied from other works: i, pp. $336,4{ }^{2}, 638-639$; ii, pp. $450,45^{1}$, 509-5t:

Voigt, [C. G. ?] Neueste acquisitionen des halle'schen mineralogischen museums. Ber. naturw. ver. Harzes, I $840-46$ (2e aufl.), p. $26.4^{\circ}$. Wernigerode. I 556 .

Exhibition of four species of Blattina from Wettin and Löbejun, and of an insect to be cailed Acridites carbonatus by Germar ; these were atierwards described by Germar in Miinster's Beiträge.

Vollmar. Ueber fossile entomologie. Gistl, Faunus, $2: 56-62$. So. München. Is 35 .

Of a general nature, closing with a list of fossil Coleoptera, borrowed from Keferstein.

van Volzem, Camille. Note critique sur l'interprétation donnée par M. de Borre d'une .... em. preinte fossile, celle du Pachytylopsis Persenairei. Comtes rendus soc. ent. Belg., (2), 24 : 20-26, fig. 8o. Bruxelles. 1876 .

Ann. soc. ent. Belg., 19 : 28-34. 80. Bruxelles. I 876 .

This posthnmous note is introduced by explanatory remarks of Weyers. The author concludes that it is donbtful whether the fossil is the wing of an orthopteron; that it certainly is not an acridian, and has nothing in common with Pachytylus.

Walch, J. E. I. See Knorr, G. IV.

Walchner, Fritz Hermann. Der practische naturforscher. Ein unentbehrliches hand- und hülfsbuch für freunde der naturwissenschaften. 8o. Karlsruhe. $1842-44$. pp. I19s. Each part also contains sep. t. p., and I f. table.

Abtheilung III, Der petrefactolog $\left(18_{43}\right)$, contains a chapter on Fossiler iusecten, pp. 534-539, in which, especially in foot-110tes, the genera then known are enumerated; nothing new is added.

Walker, John Francis. Fossil insects in the Bournemouth leaf beds. Gcol. mag., $7: 240$. 80. London. IS70.

A bibliographical reference.

Waliace, Alfred Russel. The geographical distribution of animals; with a study of the relations of living and extinct faunas as elucidating the past changes of the earth's surface. $2 \mathrm{v}$. 8o. London. I876. - The same: New York. 2 v. 8o. i 876 . Vol. I, pp. 24,503 , pl. 13, maps 5 ; - vol. 2, pp. 10, 607, pl. 7 , maps 2 .

In a section entuled: Antiquity of the genera of insects, $i$. pp. 166-168 (both editions), he concludes that "many of the larger and more important genera of insects date back to the beginning of the tertiary period, or perhaps beyond it; but the family types are far older." The section abounds in errnrs.

Wallace, A. R. Colour in nature. Nature, 19: 501-505. $4^{\circ}$. London. 1379 .

Review of Grant Allen's Colour sense, in which, p. 50 r, he contends for the probability of flowering plants and accompanying butterflies in the carboniferous.

Wallace, A. R. Did flowers exist during the carboniferous epoch? Nature, 19: 582. $4^{\circ}$. London. I879.

Maintains the lepidopterous nature of Breyeria. See also McLachlan, R.
Wallace, A. R. See also Auon.

Wallerius, Johan Gottskalk. Systema mineralogicum, quo corpora mineralia in classes, ordines, genera et species suis cum varietatibus divisa describuntur, atque observationibus, experimentis et figuris aeneis illustrantur. Editio altera correcta. 2 vol. $8^{\circ}$. Vindobonae. I 778 . Vol. I, pp. (16), $448,(38)$, port., pl. - vol. 2, pp. (12), 640, (60), pl.

$\S_{154}$, ii. pp. 53\$-546: Entomolithi, contains, under the heads of 'Typulithi and Entoma, a catalogue of the fossil insects then known.

Wanklyn, A. Description of some new species of fossil ferns from the Bournemouth leaf-bed. Ann. mag. nat. hist., (4), 3: 10-12, pl. I. So. London. I 869.

Mentions an undetermined insect.

Warren, John Collins. Remarks on some fossil impressions in the sandstone of Connecticut River. 8. Buston. I $S_{54}$. pp. $54, \mathrm{pl}$.

On p. 37 he refers some of the impressions as perhaps made "by the feet and bodies of large insects."

Waterhouse, Charles O. See Woodward, H.

Webster, Thomas. On the fresh-water formations in the Isle of Wight, with some observations on the strata over the chalk in the south-east part of England. Trans. geol. soc. Lond., 2 : 161-254. $4^{\circ}$. London. I8I4.

Mentions, pp. 194, 206, branches of trees found in the tertiary clays of Sheppey, bearing excrescences produced by insects ; and, p. 230 , the discovery of beetles in the tertiary deposits at Newport.

Weiss, Christian Ernst. See Dohrn, A.

Westwood, John Obadiah. Characters of Embia, a genus of insects allied to the white ants (Termites); with descriptions of the species of which it is composed. Trans. linn. soc. Lond., $17: 369-374$, pl. II. $4^{\circ}$. London. 1837 .

In a postscript on p. 374 , two species from gum copal are noticed.

Westwood, J. O. On the economy of the genus Palmon of Dalman with descriptions of several species belonging thereto. Trans. entom. soc. Lond., 4 : 256-281, pl. 10 pars. 80. London. 1847.

Redescribes some of Dalman's copal insects; the living species whose economy is known are parasitic on eggs of Mantidae.

Westwood, J. O. Description of the remains of fossil insects from the purbeck formation of Dorset and Wilts, and from the Stonesfield slate of Gloucestershire. Quart. journ. geol. soc. Lond., 9: proc. 344. $8^{\circ}$. London. IS 53 .

Unpublished; apparently the same as the next.

Westwood, J. O. Contributions to fossil entomology. Quart. journ. geol. soc. Lond., ro : 378-396, pl. I4-18. 8\%. London. I 854 .

Abont one hundred and fifty specimens are figured and fiftyniue species named. They are nearly all from Purbeck strata, about half of them Coleoptera, and the remainder are referred mostly and about equally to Hemiptera, Orthoptera and Neuroptera. The separata have a title on reverse of $\mathrm{p} 37^{8}$.

Westwood, J. O. Sur une empreinte trouvée en Angleterre dans les schistes houillers et supposée pouvoir être celle d'une chenille. Compt. rond. soc. ent. Belg., (2), no. 22, pp. 6-7. 80. Bruxelles. 1876. Ann. soc. ent. Belg., I9, compt. rend., 4-5. $8^{\circ}$. Bruxelles. I 876 .

Translation by Weyers of a passage of Westwood's from Brodie's work on the secondary insects of England, in which a supposed caterpillar (since recognized as a myriapod) is described. Weyers adds a few comments.

Westwood, J. O. See Brodie, P. B.; Doubleday, E., and Westwood, J. O. ; and Woodward, $H$. 
Weyenbergh, H. Een kort overzigt der entomologische fossiele schatten van Teyler. Tijdschr. entom., (2), 3: 195-196. So. 'sGravenhage. 1867.

Brief notice of the fossil arthropods of 'Teyler's museum.

Weyenbergh, H. Sur les insectes fossiles du calcaire lithographique de la Bavière, qui se trouvent au Musée Teyler. $8^{\circ}$. Harlem. I\$69. t. p., pp. 48, pl. 4. Arch. mzes. Teyl., 2 : 247-294, pl. 34-33. 8. Harlem. r 869 .

Describes forty-eight species, many of them new ; preceded by a list of the sixty previously known jurassic hexapods, and followed by five pages of general considerations.

Weyenbergh, $\mathrm{H}$. Prodromus en algemeene beschouwing der fossiele insekten van Beijeren. 80. ['sGravenhage.] 1869. pp. 19. Tijdschr. entom., (2), 4:230-248. $8^{\circ}$. 'sGravenhage. 1869.

$A$ list of one hundred and four insects is given, followed by general remarks, including, pp. 12-14 $(241-243)$, a comparison of the secondary insects of England and Bavaria; pp. 231-234 are printed $131-134$.

Weyenbergh, H. Notes sur quelques insectes du calcaire jurassique de la Bavière. $8^{\circ}$. Harlem. 1873. t. p., pp. 7. Arch. mus. Teyl., 3:234-240. 80. Harlem. IS73.

Further discussion of the affininies of four species included in the preceding paper, especially of Hasseltides primigenius (with the opinions of van Hasselt on this species) and of Sphinx Snelleni.

Weyenbergh, H. Varia zoologica et palaeontologica. Periód. zool., org. soc. entom. argent., I : 77-I I I, lam. 2-3. 80. Butenos Aires. 1874.

"Insectes fossiles," pp. 81-ro7, lam. 3, includes descriptions and discussion of half a dozen Solenhofen insects, of whicb two or three are new, followed by the list mentioned under the next entry, and a list, p. 107, of the secondary insects of Bavaria not represented in the Musée Teyler.

Weyenbergh, H. Enumération systématique des espèces qui forment la faune entomologique de la période mésozoïque de la Bavière; en mếme temps Supplément du Catalogue de la collection paléontologique du Musée Teyler. 80. [Buenos Aires, I874.] pp. 20. Periód. zool., org. soc. entom. argent., I : 87-106. 80. Buenos Aires. I874.

Contains two hundred and sixty-five numbers, of which about thirty are undelermined; full references to descriptions and illustrations are added.

Weyers, Joseph Leopold. See de Borre, A. P.; van Volxem, C.; and Westwood, J. O.

White, Adam. See Hagen, H. A.

White, Charles A. Report on the paleontological field work for the season of 1877 . Ann. rep. U.S. geol. surv. terr., I I : I6I-272. $8^{\circ}$. Washington. 1879 [1880].

Contains a notice of Corydalites fecundum and its geological position.

White, C. A. Progress of invertebrate palaeontology in the United States for the year 1880. Amer. nat., $15: 273^{-279}$. So. Philadelphía. I 88 r.

Notices papers by Scudder.

White, C. A., and Nicholson, H. A. Bibliography of North American invertebrate paleontology, being a report upon the publications that have hitherto been made upon the invertebrate paleontology of North America, including the West Indies and Greenland. So. Washington. 1878. pp. I32. Misc. publ. U.S. geol. surv. terr., 10.

White, C. A., and Nicholson, H. A. Supplement to the Bibliography of North American invertebrate paleontology. Bull. U.S. geol. surv. terr., 5: I43-I 52. $8^{0}$. Washington. I879.

I. C.
Wiedemann, Christian Rudolph Wilhelm. See Rathke, M. H.

Wigand, Johannes. Vera historia de succino borvssico. De alce borvssica \& de herbis in borussia nascentibus. Item de sale creatvra Dei salvberrima consideratio methodica \& theologica per Iohannem VVigandvm D. Qvondam episcopum pomezaniensem. Iam vero primvm in studiosae iuuentutis gratiam in lucem edita. Studio et opera Iohannis Rosini pastoris vvickerstadensis. I $2^{\circ}$. Ienae. [MD]XC. ff. (12), I 53, (5).

In a section: De vermiculis in succino, ff. 26-29, he mentions culices, formicae, aranei parui papiliones.

Williston, Samuel Wendell. Some interesting new Diptera. Trans. Conn. acud. arts sc., $4: 243^{-246}$, fig. So. New Haven. I880.

In describing a new nemestrid from Washington Territory, he discusses the fossil Palembolus of Florissant.

Winkler, T. C. Musée Tevler. Catalogue systématique de la collection paléontologique. So. Harlem. I 863 . t. p., pp. 4, 608.

Arachnides, p. 42I ; Insectes, pp. 422-429. 265 numbers are given, including over two hundred undetermined species.

Wollaston, Thomas Vernon. Note on the remains of Coleoptera from the peat of Lexden brickpit. Quart. journ. geol. soc. Lond., 19:400-40I. 80. London. 1863.

Indicates briefly the generic affinities of a dozen species.

Wollaston, T. V. See also Fisher, O.

Woodward, Henry. Notes on some fossil crustacea, and a chilognathous myriapod, from the coal measures of the west of Scotland. Trans. geol. soc. Glasgow, 2 : 234-248, pl. 3. 80. Glasgow. I 867 .

Describes a Xylobius on pp. 235-237, and enumerates the true insects from the coal formation on pp. $237^{-2} 40$.

ABSTRACT: Notes on a chilognathous myriapod and some fossil crustacea from the coal measures of the west of Scotland. Geol. mag., $4: 130-131$. 80. London. 1867 .

Woodward, H. On Euphoberia Brownii H. Woodw., a new species of myriapod from the coalmeasures of the west of Scotland. Geol. mag., 8 : 102-104, pl. 3, figs. 6-7. 80. London. I871.

Describes and compares with $\mathrm{E}$. armigera of the Illinois carboniferous beds.

Woodward, H. On the discovery of a new and very perfect arachnide from the ironstone of the Dudley coal-field. Geol. mag., $8: 3^{\mathrm{S}} 5-388$, pl. i r. 80. London. I87 I.

Describes and figures a new specimen of the arachnid, to which Buckland, supposing it a beetle, formerly gave the name of Curculioides Prestvicii. A list of fifty-four paleozoic insects is appended. An abstract will be found in Rep. Brit. assoc. adv. sc., 41 : not., 112-113. 8०. London. 1872 .

Woodward, H. A monograph of the British fossil crustacea belonging to the order Merostomata. $4^{\circ}$. London. I866-i $\$ 73$. t. p., pp. 2, 263, pl. 36. [Publ.] paleontogr. soc., I 366-78.

Includes, pp. $171-174$, in part iv. (1872), Eurypterus (Euphoberia) ferox, since held by Woodward and others to be a myriapod.

Woodward, $H$. On a new arachnide from the coal measures of Lancashire. 80. London. I $S_{72}$. p. 3. Geol. mag., 9: $3^{S}{ }_{5} 3^{8} 7$. So. London. 1872 .

Describes Architarbus subovalis and compares with A. rotundatus from carboniferous beds of Illinois. Also entitled on cover of separata : On a new fossil arachnide.

Woodward, H. On some supposed fossil remains of Arachnida (?) and Myriopoda from the English coal-measures. Geol. mag., 10: 104-112, figs. 80. London. 1873 . 
Separate also entitled: On British fossil arthropoda. $80^{\circ}$ London. 1873. pp. 9, figs. 11. Discusses the affinities of "Eurypterus? (Euphoberia) ferox," referring it to the Myria pods.

Woodward, H. On the discovery of a fossil scorpion in the British coal measures. Quart. journ. geol. soc. Lond., $3^{2}: 57-59$, pl. 8. 8o. London. I876.

Describes and figures three distinct fragments of a scorpion, referred to one species called Eoscorpius anglicus. An abstract under the title "The discovery of a fossil scorpion in the English coal measures" is given in Hardw. sc. gossip, 1876: 20 . 8. London. 1876 .

Woodward, H. On a remarkable fossil orthopterous insect from the coal measures of Scotland. Quart. journ. geol. soc. Lond., $3^{2}: 60-64$, pl. 9. 80. London. 1876.

Describes and figures Lithomantis carbonarius, which with Westwood, Waterhouse and McLachlan he considers as belonging in "the neighbourhood of the Mantidae." Corydalis (Gryllacus) Brongniarti and a modern species of Blepharis are also figured for comparison as related to it. A list of fifty-eight paleozoic insects is appended. An abstract, under the title "Remarkable fossil orthopterous insect from the coal measures of Britain," appeared in Hardw. sc. gossip, 1876:20. $80^{\circ}$. London. 1876 . See also Heer, 0 .

Woodward, H. On the occurrence of Branchipus (or Chirocephalus) in a fossil state, associated with Archaeoniscus and with numerous insect remains in the eocene fresh-water limestone of Gurnet Bay, Isle of Wight. Geol. mag., n. s., 5:88-89. 80. London. 1878 .

Abstract of the next, with slightly differing title, but published earlier than it, and containing a fuller list of insects.

Woodward, H. On the occurrence of Branchipus (or Chirocephalus) in a fossil state, associated with Eosphaeroma and with numerous insect remains in the eocene fresh-water (Bembridge) limestone of Gurnet Bay, Isle of Wight. Quart. journ. geol. soc. Lond., 35:342-350, pl. 14. 80. London. I879.

The insects are mentioned on p. 344 , mostly in a List of insect remains from Gurnet Bay, near Cowes, Isle of Wight determined by the late Frederick Smith. One hundred and twenty-five specimens are mentioned but only eighteen genera or families specified and one species.

Woodward, H. See Evans, C. E.

Woodward, H. et al. Notes on fossil insect remains. Geol. mag., 10: I-2. 80. London. I873.

A résumé, by the editors of the journal, of papers that have appeared on the subject in their magazine, by Phillips, Kirkby, Scudder, Woodward and Butler.

Worthen, Amos Henry. See Meek, F. B., and Worthen, A. H.

Wyman, Jeffries. See Deane, J.

Yzem, E. Versteinerte insecten-zellen. Ber. naturw. ver. Harzes, $1840-46,2^{e}$ aufi.,p. 26. $4^{\circ}$. Wernigerode. 1856 .

Exhibition of drawings of insect-cells like bee-comb from jurassic (?) beds at Chausseebau near Harsleben.

Zaddach, Ernst Gustav. Ueber die bernsteinund braunkohlenlager des Samlandes; erste abhandlung. Schrift. phys-ökon. gesellsch. Königsb., I : $\mathrm{I}-44, p l$. I-4. $4^{\circ}$. Königsberg. 1860.

Notices, pp. 3-4, the numbers of insects found in amber, all distinct from living forms; and on $\mathrm{pp}$. 20-21 gives a table of the number of genera and species of the difierent orders of insects, with special mention of the remarkable genera Archaea and Amphientomum.

Zaddach, E. G. Amber; its origin and history, as illustrated by the geology of Samland. Quart. journ. science, 5 : 167-185, pl. (2). 80. London. 1868.

Mainly compiled from the author's previous writings on the amber beds. It contains, however, as new matter, a plate of amber insects with explanation by Frederick Smith and pp. $184-185$, a list of the principal works on amber and the organic remains preserved in it, furnished by the editors.

○ Termiten im Bernsteinwalde. Neue preuss. prov.blätt., (3), 1: 61-64. 160. Königsberg. 1858 .

A popular account, drawn from Hagen's Monographie der termiter.

\section{APPENDIX.}

In this appendix I have placed not only such references as were overlooked in printing the preceding pages, and those that have been published during the two years of its passage through the press, but also all contributions to the literature of fossil insects of which only incomplete memoranda could be obtained, through allusions to them in the works of others. Diligent search has been made for the early literature of the subject, and especially of a mber insects. Perhaps not one half the works or sapers concerning amber referred to in bibliographies have been procurable in this country, and of those seen comparatively few contain references to insectenclosures. The scattered allusions to amber insects taken from older authors and published later than the seventeenth century have in general been left unnoticed, as wholly valueless and uninteresting; but all others, where possible, have been introduced into the list in a more or less perfect form. The best notice of the early literaiure of amber will be found in Boekmer's Bibl. script. hist. nat., 4, i: 468-477. 80. Lipsiae. 1788. The few papers concerning the relationship of the Merostomata and Arachnida have also been introduced into this appendix, but the extensive literature of the Merostomata generally has not been added, as it should be, were the views of Van Beneden and Lankester to prove correct.

$I$ am much indebted to many correspondents, but especially to Dr. H. A. Hagen, for assistance in preparing this bibliography, which will certainly strike even those well acquainted with the subject as unexpectedly extensive. More than four huredred authors are represented as having concermed themselves more or less with fossil insects. - S. H. S.

Agassiz, Jean Louis Rodolphe. The primitive diversity and number of animals in geological times. 8.. [New Haven.] 1854. pp. 16. Am. journ. sc., (2), I7: 309-324. 80. New Haven. 1854 .

Devotes a paragraph on p. $8(316)$ to insects, and prophesies their discovery anterior to the carboniferous period.

Aldrovandus, Ulysses. De animalibvs insectis libri septem cvnı singvlorvm iconibvs ad viuum expressis. fo. Bononiae. 1638. t. p., pp. (8), 767 , (44).

The section, p. 700 , De vermibus in lapidibus, \& metallis nascentibus cap. 8 , contains nothing original.

Aldrovandus, U. Mvsaevm metallicvm in libros IIII distribvtvm. fo. Bononiae. I648. t. p., ff. 2, pp. $979,(13)$.

Cap. y8, De svccino, sev electro, pp. 403-418, refers briefly to insect inclusa on p. 406, under the side heading Quae animantes in svccino sint.

André, Edouard. See Brongniart, C. J. E.

Assmann, A. Ueber die von Germar beschriebenen und im paläontologischen museum zu München befindlichen insekten aus dem lithographischen schiefer in Bayern. Amtl. ber. versamml. deutsch. naturf., 50: I91-192. $4^{\circ}$. München. 1877 .

A brief statement of his views of the modern groups in which Germar's species should be placed.

Aurifaber, Andr. Succini historia, oder Bericht woher der agt- oder börnstein ursprünglich komme. $4^{\circ}$. Königsberg. I 551 .

Not seen. Dr. Hagen informs me that it contains references to insects in amber, and is therefore one of the earliest works mentioning them. He thinks, indeed, that Münster's earlier 
mention of them may have been due to information received direct from Aurifaber; both were disciples of Luther. Later editions were published in 1557 and 1572 in $4^{\circ}$, and, rendered into Latin verse by Scholzius, in 1593 and 1671 in $80^{\circ}$.

Aycke, Johann Christian. Fragmente zur naturgeschichte des bernsteins. I $6^{\circ}$. Danzig. I835. pp. 8, 107 .

Contains a section: In bernstein eingeschlossene organische gegenstände, pp. $58-64$, where the author states that insects occur most frequently in transparent amber and in such as shows a concentric structure; oftener also in amber brought up from the sea and only rarely in that dug from the earth. He also criticises various authors and especially Schweigger for confounding copal and other gums with amber.

Aymard, A. Rapport sur les collections de M. Pichat-Dumazel. Congr. scient. France, sess. $22: 42$. 8. Le Puy. I854.

Not seen; quoted from Oustalet. Names but neither describes nor figures seven insects from Le Puy, of which three belong to Coleoptera, three to Diptera and one to Neuroptera.

Baily, William Hellier. Notice of plant remains from beds interstratified with the basalt in the county of Antrim. Quart. journ. geol. soc. Lond., 25 : 162, 357-362, pl. I4-1 5. So. London. I 869.

Two elytra of beetles "of distinct species, resembling those of some of the smaller Carabidae," are mentioned, pp. 359-360, as occurring in the leaf-bed, and are figured, pl. 14, figs. 14-15 in the explanation of the plate, pp. $361-362$, they are compared to Rhynchophora.

Bargagli, Piero. Di tre opuscoli sugli insetti fossile e sulle formazione inglesi e straniere nelle quali sono stati scoperti avanze d'insetti, pubblicati da H. Goss. Bull. soc. ent. ital., I 2 : $127^{-1} 3^{8} .8^{\circ}$. Firenze. I\$SO.

A very full abstract of Goss's first paper.

Barrois, Jules. See Debray, H.

van Beneden, Edouard. De la place qui les limules doivent occuper dans la classification des arthropodes. Compies rend. séances soc. ent. Belg., 1871-72: 9-1 I. 80. Bruxelles. I871.

Ann. soc. ent. Belg., I 5, compte rend., 9-II. 80. Bruxelles. I872.

Translation: On the systematic position of the king crabs and trilobites. Ann. mag. nat. hist., (4), 9: 98-99. 8०. London. 1872.

Concludes from a study of the embryonic development of Limulus that it presents the greatest analogy to that of scorpions and other araclnids from which the king crabs cannot be separated. "The Trilobites as well as the Eurypterida and the Poecilopoda must be separated from the class Crustacea, and form, with the Scorpionida and the other Arachnida, a distinct branch, the origin of which bas still to be ascertained."

van Beneden, Pierre J. et Coemans Eugène. Note sur un insecte et un gastéropode pulmoné du terrain houiller. Ann. sc. nat., (5), zoöl., 7 : 264-277, pl. I, figs. I-IO. 80. Paris. I867.

Reprint of the paper witl similar title, supra.

Berendt, G. C. Bitte, die bei gräbereien bisweilen vorkommenden fossilen zapfen, fossiles holz und bernstein-insekten betreffend. Preuss. provinz. blätt., I $5: 623-625$. I 6 . Königsberg. I 836 .

Records, p. 625, the occurrence of a Nepa in amber.

Berendt, G. C. See also Hope, F. IV., and Troost, G.

Bertkau, P. Ueber einige fossile arthropodenreste aus der braunkohle von Rott. Sitzungsh. niederrhein. gesellsch. Bortn, I878: 70-71. 80. Bonn. 1878 .

Principally concerned with the arachnids described in his other paper quoted, and especially with Argyroneuta antiqua.

Bleicher, Marie Gustave. Note sur la découverte d'un horizon fossilifère à poissons, insectes, plantes, dans le tongrien de la Haute-Alsace. Bull. soc. géol. France, (3), 8 : 222-229. 8\%. Paris. IS80.

Records, pp. 226-227, the occurrence at Rouffach of two insects, referred to Cicadariae and Hymenoptera, and of an apterous articulate, probably an isopod crustacean, but perhaps a cockroach.

Bock, Friedrich Samuel. Versuch einer wirthschaftlichen naturgeschichte von dem königreich Ost- und West-Preussen. 5 v. 160. Dessau. 1782-85.

Bd. $2(1783)$ contains a short passage, pp. 196-197, on insects in amber.

de Borre, Alfred Preudhomme. Note sur le Breyeria borinensis (supra). Ann. soc. entom. Belg., 22 , compte rend., 77-83. $8^{\circ}$. Bruxelles. I879.

de Bosniaski, S. La formazione gessoso-solfifera e il secondo piano mediterraneo in Italia. Atti soc. tosc., sc. nat. 2, proc. verb., 90-100. $8^{\circ}$. Pisa. 1880.

Refers, p. 93, to Libellula Doris and other insects as occurring at two horizons.

Boué, Ami. See Audouin, V.

Box, - . ['Title of paper unknown.] Ann. rep.roy. inst. Cornwall, $26:-8^{\circ}$. Truro. I 844 .

Notices elytra of beetles in a layer of sand with vegetable matter beneath a marsh on Millenbreath beach, Cornwall. Cf. Ussher, Geol. mag., (2), 6:25r. $8^{\circ}$. London. 1879.

Bradley, Frank Howe. Geology of Grundy county. Geol. surv. Ill., 4, chapt. I3, pp. 190-206. 8०. [Springfield.] I870.

Contains, p. 196, a list of the carboniferous insects of Mazon creek.

Bradley, F. H. Geology of Vermilion county. Geol. surv. Ill., 4, chapt. 16, pp. 241-265. 80. [Spring. field.] I870.

Refers, p. 253 , to a species of Miamia from the carboniferous rocks near Georgetown.

Brauer, F. See also Fritsch, A., and Hagen, H. A.

Brodie, P. B. Contributions to the geology of Gloucestershire, intended chiefly for the use of students. Geologist, [I] : 4I-48, 8I-88, 227-233, 289-29I, $369-377.8^{\circ}$. London. $185^{8}$.

Insects are referred to on pp. 47,231 and 375 , mostly from the lias.

Brodie, P. B. On fossil Arachnidae, including spiders and scorpions. I $6^{\circ}$. Warwick. I882. pp. 8 .

A general account of what is known of fossil spiders, read before the Warwickshire naturalists' field club in March, 1882.

Brongniart, Charles [J. E.] Sur la découverte d'un orthoptère coureur (supra). Bull. hebdom. assoc. sc. France, 22 : 172-173. 80. Paris. 1878.

Brongniart, C. J. E. Note sur les tofs quaternaires de Bernouville près Gisors (Eure). So. Paris. I88o. pp. 3. Bull. soc. géol. France, (3), 8: 418-420. 80. Paris. I880.

Records finding the larva of Stratiomys, p. 2 (419).

Brongniart, C. J. E. Recherches pour servir à l'histoire des insectes fossiles. Les hyménoptères fossiles. Fasc. I. 80. Paris. ISSI. Pp. 22.

Forms an Annexe au Species des hyménoptères d'Europe par M. Ed. André. The single livraison published contains introductory remarks on the rôle of insects in the world, and the mode of their preservation in a fossil state, followed by a list of the paleozoic, triassic and liassic insects.

Bruckmann, A. E. Flora oeningensis fossilis. Die oeninger steinbrüche, das sammeln in denselben und die bis jetzt dort gefundenen pflanzenreste. fahresb. ver. vaterk. naturk. Württemb., $6: 215-238$. So. Stuttgart. I850.

The introductory part, pp. $215-225$, gives an account of the different beds of the Oeningen quarries and the animals as well 
as plants characteristic of each. Insects are mentioned on pp. $2 \times 7$ and 222 . 'The appendix, ib. 8: $252-25+(1852)$, refers only to plants.

Brückmann, Franciscus Ernestus. De fabulosissimae originis lapide, arachneolitho dicto, epistola ad virum clarissimum ... Albertum Rittervm. $4^{\circ}$. Wolffenbuittelae. I 722 . pp. 16, pl. I.

Not seen; referred to by Kundmann.

Brückmann, F. E. Thesaurus subterraneus, du. catus Brunsvigii, id est: Braunschweig mit seinen unterirdischen schätzen und seltenheiten der natur. $4^{\circ}$. Braunschweig. 1728 . pp. (4), 156, pl. 25.

On pp. roo-ror under the heading: Von denen tubuhs vermicularibus des closters St. Marlentahl, certain tubes composed of globular pellets are referred to water-insects and figured on pl. 19.

Buckton, George Bowdler. Monograph of the British Aphides. 3 vol. So. London. IS75-188r. Vol. i.: - t. p., ded., pp. 3, I93, pl. $3^{3}$; - vol. ii : t. p., pp. 176 , pl. $39-\$ 6$; - vol. iii.: t. p., pp. 2, I42, pl. 87-I14.

Vol. 3. pp. 2-4 treat of the successive appearance of insects in time, with special reference to the aphides. The author informs me that some plates of fossil aphides will be given in a future volume of this uncompleted work.

Butler, A. G. On fossil butterflies (supra).

A similar account appeared in Hardw. sc. gossip, $1873: 260-$ 261 under the title: The oldest fossil butterfly.

Capellini, Giovanni. Pesci ed insetti fossili nella formazione gessosa del Bolognese. Gazz. dell' Emilia, no. 14 I. 1869 .

Not seen: quoted from Malfatti.

Capellini, G. La formazione gessosa di Castellina marittima e i suoi fossile. Mem. accad. sc. ist. Bologna, (3), 4: 525-603, pl. 1-9. $4^{0}$. Bologna. 1873 .

On pp. 539 and 557 catalogues Libellula Doris Heer (larva) from Limone, etc.

Capellini, G. Nuove ricerche sul calcare a amphistegina strati a congeria e calcare di leitha dei Monti Livornesi. Rend. sess. accad. sc. ist. Bologna, 1874-75: 130-1 35. 80. Bologna. I875.

Refers, p. r33, to the occurrence of the larvae of Libellula at Limone, etc.

Capellini, G. Nota sulla geologia toscana. Rend. sess. accad. sc. ist. Bologna, I874-75: 22-24 $8^{\circ}$. Bologna. 1875 .

Refers, p. 24, to the occurrence of larvae of a Libellula in tertiary beds near Pane e Vino.

Capellini, G. Il calcare di leitha, il sarmatiano e gli strati a congerie nei Monti di Livorno, di Castellina marittina, di Miemo, e di Monti Catini. Considerazioni geologiche e paleontologiche. Atti accad. lincei, (3), mem. classe sc. fis., 2 : 275-291. $4^{\circ}$. Roma. $187 S$.

Gives on p. 285 a list of six insects found in the diatomaceous schists of Gabbro, two identical witb Oeningen species.

Capellini, G. Gli strati a congerie o la formazione gessosa-solfifera nella provincia di Pisa e nei dintorni di Livorno. Atti accad. lincei, (3), mem. sc. fis. 5: 375-427, pl. I-9. $4^{\circ}$. Roma. I880.

Refers in sevcral places to the occurrence of insects, and especially of larvae of Libellula in different strata and localities.

Chambers, Victor Tousey. Burrowing larvae. Nature, 25: 529. $4^{\circ}$. London. I882.

Compares recent and fossil "mines" of lepidopterous larvae, referring to Hagen's statement on a previous page.

Charntre, E. See Lortel, L. et Charntre, E.
Cordus, Valerius. Sylua, qua rerum fossilium in Germania plurimorum metallorum, lapidum et stirpium variarum notitiam lapidum brevissime persequitur. fo. Tiguri. $156 \mathrm{r}$.

Not seen; said to contain references to fossil insects from Oeningen.

Croizet ('abbé). Quelques observations sur le Puy de Corent Ann. acul. Clerm. Forr., I1 : 135I 55. 8o. Clermond Ferrand. 1838 .

Not seen; said to refer to the caddis fly cases of the indusial limestone of Auvergne.

Dallas, IV. S. See Müller, F.

Dawson, George Mercer. Sketch of the geolngy of British Columbia. $8^{\circ}$. London. IS8I. pp. r9. Geol. mag., (2), 8: 1 56-162, 214-227. S०. London. ISSI.

Refers, p. $6(162)$, to the general conclusions furnished by the tertiary insects of the interior p!ateau.

Dawson, J. W. On some remains of palæozoic insects (supra).

ABSTRACT: On insects from the carboniferous and devonian formations. Geol. mag., 4: 374. So. London. I867.

Taken from the Shontreal Gazette of May r, 1867. An abstract also appears in A mer. journ. sc., (2), $44: 116.80^{\circ}$. New Haven. 1867 .

Dawson, J. W. The chain of life in geological time; a sketch of the origin and succession of animals and plants. 16 $6^{\circ}$ London. [iS8o.] pp. I6, 272 , illustr.

In the chapter on the first air breathers a considerable number of insects are mentioned and figured, pp. $\mathrm{r}_{30-1} 5 \mathrm{r}$, figs. $\mathrm{r}_{23}, 126-$ 132, including for the first time Prodryas, a fossil butterfly from Colorado.

Dawson, J. IV. The oldest-known insects. Nature, $24: 483-484,4^{\circ}$. London. I $83 \mathrm{r}$.

Shows the devonian age of the cordaite shales of New Bruns. wick, in which the oldest known insects occur, from stratigraphical and botanical evidence, in opposition to the assumption of Hagen.

Debray, Henri. Tourbières du littoral flamand et du département de la Somme. Bull. soc. géol. France, (3), 2: 46-49. 80. Paris. IS74.

Records the discovery, p. 48 , of brilliant elytra of Donacia in peat along the Flemish coast.

Debray, H. Communications diverses au sujet des tourbières : castors; ossements de baleines; élytres de donacies; squelette humain des tourbières d'Aveluy; cranes; bois. Ann. soc. géol. nord, 5: 125-135. $8^{\circ}$. Lille. 1878 .

Under the heading Insectes, refers to the discovery in peat of Ardres of Donacia sericea, determined by J. Barrois, pp. $127-128$. Separately issued, without change of pagination but with a titlepage. 80 . Lille 1878 .

Debray, L. Êtude géologique et archéologique de quelques tourbières du littoral flamand et du département de la Somme. Mém. soc. sc. agric. arts Lille, (3), I I : 433-487, pl. I3. 80. Lille. 1873 .

Contains a brief paragraph, p. $45 \mathrm{r}$, on the few beetles fnund.

Deichmüller, J. V. Fossile insecten aus dem diatomeenschiefer von Kutschlin bei Bilin, Böhmen. $4^{\circ}$. Halle I88I. pp. 39, pl. Nova acta Leop.Carol.-deutsch. akad. naturf., 42 : 293-33I, tab. 2 I. $4^{\circ}$. Halle. IS8I.

Describes and figures thirteen species, all but one of them new, and mostly Coleoptera. They indicate a warmer climate at the time.

Demole, Isaac. See Heer, O.

Dohrn, Carl August. Zur literatur uiber fossile 
insecten. Stcit. entoin. zeit, $42: 338-359$. 8\%. Stettin. $188 \mathrm{r}$.

Gives a résumé of Hagen's criticism ct Scudder's Devonian insects.

Douglas, I. IV. et al. A species of stylopidae fossil in amber. Entom. monthl. may., It: is-I9. 8. London. I87i.

A notice by the editors of the magazine of Menge's Triaena.

Dupont, Edouard Sur la découverte d'ossements d iguanodon, de poissons et je végetaux dans la fosse Sainte-Barbe du charbonnage de Bernissart. Bull. acad. sc. Belg., (2),46:3\$7-408. So. Bruxelles. I 878 .

Mentions, p. 395, the occurrence of insect larvae in this wealdian deposit.

Eaton, A. E. The oldest fossil insects. Nature, 23: 507. $4^{\circ}$. London. I88r.

Rep'y to Scudder's criticisms (in Devonian insects) of remarks on fossil Ephemeridae in Ealon's Monograph.

Eaton, A. E. See Scudder, S. H.

Erichson, W. F. See Maravigna, C.

Fliche, P. Sur les lignites quaternaires (supra). The insects were determined by Matthieu of the Ecole forestére.

Francius, Johannis, Prodromus arachnolithographiae. Misc. cur. acad. nat cur., (2), 5: 462-464. $4^{\circ}$. Norimbergae. 1687.

Refers oniy to the use to which lapides aranearum are put in medicine.

Fritsch, A. Fossile anthropoden aus der-stein. kohlen und kreideformation Böhmens. $4^{\circ}$. WVien. 1882 pp. 7, pl. 2. Mojs, u. Neum., Beitr. paläont. österr.-ung., 2: $\mathrm{r}-7$, taf. 1-2. $4^{\circ}$. Wien. I882.

Describes and figures a carboniferous ephemerid, Palingenia Feistmanteli, and three beetles, mines of a Tinea, eggs of a saw fly, and cases of a phryganid from the cretacenus beds of Bohemia: a résumé of the very few known cretaceous insecrs is added from Goss. Brauer and Fritsch both compared the may tyy, p. 3, to the living Palingenia longicauda.

Geikie, Archibald. A recent find in British palaeontology. Nature. $25: \mathrm{r}-3 \cdot 4^{\circ}$. London. I88r.

Contains an announcement of the discovery of remarkably perfect scorpions in the coal measures of Scotland, with some results of their study by Mr. B. N. Peach. An abstract entitled New carboniferous fossils in Scotland, extracted from the London Times will be found in Amer. nat., r5: 1021-1022. $8^{\circ}$. Philadelphia. r88r. See also Primeval Scottish scorpions.

Germar, E. F. See Assmann, A.

Goebel, Severinus. De succino libr. II. quorum prior theologicus, posterior de succini origine agit. 8. Francfurt. I $55^{\circ}$.

Not seen; Dr. Hagen informs me that it contains references to insects in amber, among the earliest known.

Goeppert, H. R. Sull' ambra di Sicilia e sugli oggetti in essa rinchiusi. $4^{\circ}$. Roma. I879. pp. 9 , figs. Mem. acad linc., (3), mem. sc. fis., 3:56-62. $4^{\circ}$. Roma. I 879.

On p. $4(58)$, he reviews the literature of the insects of Sicilian amber.

Goldenberg, F. Beitrag zur insectenfauna der kohlenformation von Saarbrücken. Zeitschr. ges. naturw., (3), 6: 184-187, figs. So. Berlin. I881.

Describes Anthracoblattina Scudderi.

Goss, H. See Scudder, S. H.
Haeckel, Ernst (Heinticht-Allgemeine entwickelungsgeschichte der organismen. Kritische grundziige der mechanischen wissenschaft von den entstehenden formen der organismen, begründet durch die descendenz-theorie. Also entitled: Generelle morphologie der organismen. Allgemeine grundzüge der organischen formen-wissenschaft, mechanish begrundet durch die von Charles Darwin reformirte descendenz-theorie. Zweiter band. 80 . Berlin. I 866. pp. I60, 462 , pl. 8.

Is the introduction insects are treated on pp. 94-102, and the views entertained of the primeval forms of the different groups sipported in part by paleontological evijence.

Haeckel, E. (H.) Natürliche schöpfungsgeschichte. Gemeinverstandliche wissenschaftliche vorträge uiber die entwickelungsiehre im allgemeinen und diejenige von Darwin, Goethe und Lamarck im besonderen. Vierte verbesserte autlage. So. Berlin. 1873. pp. 46. 6S8, pl. (I), I 5.

TRANSLATION: 'The history of creation: or the development of the earth and its inhabitants by the action of natural causes. A popular exposition of the doctrine of evolution in general, and of that of Darwin, Goethe, and Lamarck in particular. The translation revised by E. Ray Lankaster. 2 vois. I ${ }^{\circ}$. New York. i\$76. - i, pp. 20, 374, pl. (1), 1-3; ii, pp. 8, 408. pl. 4-I 5 .

Insects are treated on pp. 490-50r (transl., 2 : $178-191$ ) and their pedigrees considered, partly from seological considerations.

Haesbert, M. J. De conchylio et ape petrifactis (supra).

Reports a fossil bee in the collection of Scheidius, figured tab. 2, fig. 4 .

Hagen, H. A. Ueber .. Heterophlebia dislocata (sitpra).

1)r. Hagen informs me that the most important vein is given in the wrong place $t v$ the lithographer.

Hagen, 11. A. Notes on Tarsophlebia Westwoodii Giebel, a fossil dragon fly. Entom. monthl. mag., i: 160-16r. 8\%. London. IS64.

Hagen, H. A. Synopsis of the Psocina without ocelii. Entom. monthl, mag., ii : $221-$ I24. 80. London. I 865.

Atropos resinata from copal is described on p. $12 \mathrm{r}$.

Hagen, H. A. The oldest fossil insects. Nature, 24: $356-357.4^{\circ}$. London. I $88 \mathrm{I}$.

Is chiefly concerned with the determination of a species of Pecopteris found in the Devonian insect beds, and the conclusion is drawn that "those oldest insects will have to be considered as belonging to the lower carboniferous."

Hagen, H. A. Fossil insects of the Dacota group. Nature, 25:265-266. $4^{\circ}$. London. 1882.

A brief note recording the discovery of galls and mines in fossil leaves from Kansas and Nebraska.

Hagen, H. A. On amber Psocina from Prussia. Psyche, 3: 279. 4\%. Cambridge. ISS2.

Concludes from them that before tertiary times a great development of genera and species had occurred.

Hagen, H. A. See Dohrn, C. A.; Krantz, A.; and Scudder, S. H.

Hartmann, P. J. Succincta succini prussici historia et demonstratio (supra). An abstract will be found in Acta erud, r700: 332-336. $4^{\circ}$.
Lipsiae. 1700 .

van Hasselt, A. W. M. See Wyenbergh, H.

Haughton, Samuel. Description of a fossil spider, Architarbus subovalis, from the middle coal measures, Burnley, Lancaster. Fourn. geol. soc. Ireland, n.s., 4: 222-223, figs. 80. Dublin, etc. I 877 .

Gives a figure, without description, both of the original and of the new and better specimen. 
Heer, O. Fossile flora der Bären insel. $4^{\circ}$. Stockholm. IS7 r. pp. 5I, pl. I 5. Kongl. svensk vetenskakad. handl., 9, no. 5 .

In a section on the equivalents of the Bear island beds in America, he refers the Devonian of St. John to the lower carboniferons and mentions four species of insects described from there by Scudder.

Heer, O. New orthopterous insect in the coal measures of Scotland. Geol. mag., (2), $3: 520$. 8 . London. 1876 .

Notes some omissions of fossil cockroaches in the list of carboniferous insects attaached to Woodward's paper with a similar title.

Heer, O. See also de La Harpe, P.

Heller. See Berendt, G. C.

Henkel, Johannes Fridericus. De succino fossili in Saxonia electorali. Acta pliys. med. acad. Leop-Carol., 4:313-316. $4^{\circ}$. Norimbergae. 1737 .

Contains reference to insect inclusions on p. 316. Also said to be given $\mathrm{m}$ his Kleine miner. chym. stud., p. 539. $8^{\circ}$. Dresden und Leipzig. 1744.

Henwood, William Jory. Observations on the detrital tin-ore of Cornwall. Fourn. roy. inst. Cornwall, $4: 191-254.8^{\circ}$. Truro. 1873.

Refers to the discovery of elytra of beetles in alluvium at Perranwell, Cornwall.

Translation: Remarques sur le mineral d'étain détritique du Cornwall. Traduction, par extraits, par Zeiller. Ann. des mines, (7), 6: i I4-130. $8^{\circ}$. Paris. 1874 .

The translation omits all references to animal remains.

von Heyden, C. See von Meyer, C. E. H.

von Heyđen, C. und L. See Krantz, A.

von Heyden, L. See Capellini, G.

Heywood, James. See Heer, O.

Hislop, S. See Murray, A.

Hollingworth, George H. Description of a peatbed interstratified with the boulder drift at Oldham. Quart. journ. geol. soc. Lond., 37: 713-7I4, fig. $8^{\circ}$. London. I88I.

Reports beetles in the main bed of peat, p. 713 .

Ittiologia veronese del museo Bozziano ora annesso a quello del conte Giovambattista Gazola e di altri gabinetti di fossili veronesi con la verzione latina. fo. Verona. I796. pp. 52, 323, pl. 76.

Part I. \$27, p. 31, records in the Boza museum, "duo Asili, Cimex unus Americanus, omnes inde effosi."

\section{Jobert (ainé). See Croizet et Jobert.}

Jokély, Johann. Die tertiären süsswassergebilde des Egerlandes und der Falkenauer gegend in Böhmen. Fahrb. k.k. geol. reichsanst., $8:$ 466-515. 8\%. IVien. 1857.

Remains of insects are recorded from Eger (p. 477), Krottensee (p. $4^{82}$ ), Grasseth (p. 502).

Kawall, H. Der bernsteinsee in Kurland. Correspondenzbl. naturf. ver. Riga, 6:69-71. 80. Riga. I853.

Not seen ; said to contain something on amber insects.

Kerr, Washington Carothurs. Report of the geological survey of North Carolina. Vol. i. Physical geography, résumé, economical geology. 1875. $8^{\circ}$. Raleigh. 1875. pp. I8, 325, I 20, map, pl. (I), 8.

Reports on p. 157 the occurrence of " numerous shining wingcovers of beetles" in peat near Morganton, N. C.
Kollar, Vincent. See Reuss, A. E.

Krause, Ernst. See Scudder, S. H.

Kundmann, Johann Christian. Rariora naturae et artis, item in re medica, oder Seltenheiten der natur und kunst des kundmannischen naturaliencabinets, wie auch in der arzneywissenschaft. fo. Breslau und Leipzig. 1737. 2 t. p., ff. (8), col. 1312 (=ff. 328), ff. (I7), portr., figs., pl. I7.

Contains, col. 229-236, tab. 12, figs. 13-14, art. 28 : Vom einem geglaubten und wahren spinnen-steine, in which spiders from the jurassic rocks of Eichstädt are figured.

de Ia Harpe, Philippe. Sur un gisement de tourbe glaciaire trouvé à Lausanne. Bull. soc. vand. sc. nat., I4 : 456-458. 8o. Lausanne. I 876 .

Contains a letter from Heer who examined the organic remains in the peat and found the elytra of a Donacia.

Lankester, Edwin Ray. Limulus an arachnid. Ouart. journ. micr. sc., 21 : 504-548, 609-649, pl. 2829, figs. $8^{\circ}$. London. I88I.

An extended argument to show, mainly on anatomical and morphological grounds, that the king crabs are not Crustacea but Arachnida. With the Trilobita and Eurypterina he considers the Xiphosura as the precursors of the higher Arachnida.

Lankester, E. R. Studies in Apus, Limulus and Scorpio. $8^{\circ}$. London. I 882.

Not seen; contains the same as the preceding.

Iankester, E. R. See Haeckel, E. (H.)

Lecoq, Henri. Les époques géologiques de l'Auvergne. $8^{\circ} .5$ vol. Paris. 1867 .

Not seen ; according to Oustalet, he discusses Indusia in vol. 2 , pp. 335 and 374 .

Lochnerus, Johannes Henricus et Michael Fridericus. Rariora mvsei besleriani quae olim Basilius \& Michael Ropertvs Besleri collegerunt aeneisque tabvlis ad vivvn incisa evvlgarvnt: nunc commentariolo illustrata a Johanne Henrico Lochnero, vt virtvti toy makaritoy exstaret monvmentvm, denvo lvci pvblicae commisit \& laudationem ejvs fvnebrem adjecit maestissimvs parens Michael Fridericvs Lochnervs. fo. N. P. I7I6. pp. (22), II2, pl. 40, portr. 2.

According to Kundmann, contains references to fossil insects on pp. $34,100$.

Loew, H. Beschreibung einiger neuen Tipularia terricola. Linn. entom., 5: $3^{8} 5-406$, tab. 2. $8^{\circ}$. Berlin. I851.

Treats, pp. 400-401, pl. $z$, figs. 16-23, of the genus Toxorhina and figures three amber species.

Ioew, H. Monographs of the Diptera of North Anerica. Part 2. On the North American Dolichopodidae. 80. Washington. 1864. pp. I I, 360, pl. 3-7.

A paragraph in his Supplement, pp. 321-322, points out that A analogy to the remains of the fossil fauna of the same family analogy to the remains

Iubbock, I. Monograph of the Collembola and Thysanura. $8^{\circ}$. London. 1873. pp. 10, 276, pl. 78 .

His second chapter, miscalled Chapter III. is On the imporHis second chapter, miscalled Chanura in relation to the evolutance of the Collembola and Thysanura in relation to the evolution of the Insecta, pp. $40-54$, and takes into consideration the
facts then known of the gological history of the latter; it will be found suggestive.

McLachlan, R. Insects. Encycl. brit., ed. 9, vol. I 3 , pp. I 4I-I 54. 4\%. Edinburgh [and Boston]. I88I.

Contains a paragraph, p. ${ }_{141}$, on the Antiquity of insects. 
McLachlan, R. See Woodward, H.

Malfatti, G. Bibliografia degli insetti fossili italiani finora conosciuti. So. Milano. I8SI. t. p., pp. 12. Atti soc. ital. sc. nat., 24: - 80. Milano. ISSI.

A valuable résumé of what has beeo published concerning the fossil insects of Italy, arranged by deposits. None are older than the tertiaries. Mention is made of three or tour specimens in Italian museums, not before published.

Maravigna, C. Insectes dans l'ambre (supra).

Reviewed by Erichson with original notes in Ber. wiss. leist. entom., I 38 : 29. $8^{\circ}$. Berlin. IS ${ }^{\circ}$. Arch.f. naturg., 5, ii, 309. 8\%. Berlin. 1839. [1840.]

Maravigna, C. See Rondani, C.

Martialis, Marcus Valerius. Epigrammata. Liber 4 , section 32 .

$$
\begin{aligned}
& \text { Et latet et lucet Phaethontide condita gutta, } \\
& \text { Ut videatur apis nectare clausa suo. } \\
& \text { Dignum tantorum pretium tulit illa laborum ; } \\
& \text { Credibile est ipsam sic voluisse mori. }
\end{aligned}
$$

Some writers have thought that Martial here referred to amberinclusa.

Massalongo, A. B. P. Sopra un nuovo genere di pandanee fossili della provincia veronese. $8^{\circ}$. Verona. I853. pp. I6 (7, [20I-207]), tav. 4. Mem. accad. agric. Ver., 29: 10 7-207, pl. 1-4. 8०. Verona. I854.

Refers on p. 12 (196) to the occurrence of Neuroptera, similar in form and size to the living Libellula, with "alcune piccole api" at Monte Bolca. The only copy I have seen is that of the separate paper, in which pp. 17-end are replaced by those of the academy's memoir.

Massalongo, A. B. P. Compendium faunae et florae fossilis bolcensis (supra).

Not mentioned in Sordello's Bibl. paleont. veget. ital. (1381).

Matheron, Philippe. Compte-rendu de la visite du terrain à gypse à Aix et du volcan de Beaulieu. Bull. soc. géol. France, $13: 45$ I-465. 80. Paris. I842.

The insects of the beds at Aix are referred to in general terms on p. 454 aud their relative position pointed out.

Matheron, P. Recherches comparatives sur les dépots fluvio-lacustres tertiaires des environs de Montpellier, de l'Aude et de la Provence. $8^{\circ}$. Marseille. I862. pp. I08 (?). MTém. soc. émul. Marseille, I: 173-280. 80. Marseille. 186r.

Not seen ; gives, according to Oustalet, some notice of Aix insects.

Matthieu. See Fliche, P.

Menge, A. See Douglas, J. W. et al.

Millar, George Henry, editor. A new, complete, and universal body or system of natural history; being a grand, accurate and extensive display of animated nature ... written by a society of gentlemen. fo. London. N. D.

Not seen; according to Dr. Hagen the work mentions, p. 42x, the presence of insects in amber.

Mourlon, M. Géologie de la Belgique (supra). 2 vol. $8^{\circ}$. Bruxelles. I880-i881. i (1880), pp. 4, $3 \mathrm{I} 7$; - ii (r88I), pp. 4, I6, 392.

Refers in three brief paragraphs (i. 125, 144) to the insects reported from the coal by van Beneden and de Borre, and from the oolite by the latter; the carboniferous species are also catalogued (ii. 57) as well as larvae of insects from the wealden of Hainaut (ii. 82 ).

Müller, Fritz. Facts and arguments for Darwin; with additions by the author; translated by W. S. Dallas. I6\%. London. I869. pp. (8), I44.

Argues in favor of the late acquisition of "complete" metamorphoses in insects partly from paleontological data, in a footnote to pp. I rg-12r; it does not occur in the original, entitled note to pp. 1 r
Fïr Darwin.
Münster, G. Nachtrag zu dem Aufsatze des professor Germar in theil 4 heft 2 dieser zeitschrift über die versteinerungen von Solnhofen. Teutschl. geogn. geol. dargest., 5:578-581. I60. IVeimar. I828.

Gives a list of the fossils known to him, among which, on p. 579, occurs ro arten insecten darunter 2 arten libellen. Germar's paper has nothing on insects.

Münster, Sebastian. Cosmographiae uniuersalis Lib. VI. in quibus, iuxta certioris fidei scriptorum traditionem describuntur, Omniü habitabilis orbis partiū situs, propriaeq ${ }^{\ni}$ dotes. Regionum Topographicæ effigies. Terræ ingenia, quibus sit ut tam differentes \& uarias specie res, \& animatas \& inanimatas, ferat. Animalium perigrinorum natura \& picturæ. Nobiliorum ciuitatum icones \& descriptiones. Regnorum initia, incrementa \& translationes. Omnium gentium mores, leges, religio, res gestæ, mutationes: Item regum \& principum genealogix. Autore Sebast. Munstero. fo. Basilex. I 554. ff. (12), pl. ( I4), pp. II $6_{3}$, +1 folding plate not paged.

Liber III contains, pp. $7 S_{3}-78_{4}$, a section De succino quod in Prusia legitur, in which, p. 754 , amber is said to contain "bestiolae, ut muscae, culices, apes, formicae, lacertae, \&c."

The German edition of 1598 contains this reference on pp. $1145-1146$, and that of 1628 (?) on p. 1297 .

Dr. Hagen has called my attention to this reference as perhaps the earliest mention of insects in amber. The same reference is doubtless contained in the latin edition of 1550 , perhaps in the German edition of 1544 . See Harv. Univ. Bull., ii : 285 .

Noeggerath, Jacob. Die insecten der steinkohlenflora. Frankf. convers.-blatt, I8 54:21 5-216, 223. $4^{\circ}$. Frankfurt a. M. 1854 .

Kölnische zeitung, 1854 .

Not seen; quoted from Hagen's Bibliography.

Oken, Lorenz. Einige wörter über den Oeningensteinbruch. Oken's Isis, I $840: 282-28_{3} \cdot 4^{\circ}$. Leipzig. 1840.

Refers to its fossil insects and particularly the larvae of Odonata.

von Osten Sacken, C. R. R. New genera and species of North American Tipulidae with short palpi, with an attempt at a new classification of the tribe. Proc. acad. nat. sc. Philad., I859: I97-256, pl. 3-4. 80. Philadelphia. I859.

Refers, pp. 200, 221, 251, to the relationship of Protoplasa, Elephantomyia and Rhamphidia to the species of the Baltic amber, and the identity of Toxorhina and Limnobiorhynchus.

von Osten Sacken, C. R. R. Appendix to the paper enitled New genera and species of North American Tipulidae with short palpi, \&c. Proc. acad. nat. sc. Philad., I860: I 5-1 7. 80. Philadelphia. I860.

Brief remarks on the amber genera Toxorhina and Macrochile, p. 17 .

von Osten Sacken, C. R. R. Monographs of the Diptera of North America. Part 4. On the North American Tipulidae. $8^{\circ}$. Washington. I869. pp. I I , 345, pl. 4 .

Compares the American fauna to that of the European amber fauna, pp. 37-38; devotes a couple of paragraphs, pp. 107-109, 112-114, to show that the amber species referred by Loew to Toxorrhina belong to Elephantomyia; and another to the Eriocerae of the amber, pp, 251-252.

von Osten Sacken, C. R. R. Ueber einige merkwürdigen fälle der geographischen verbreitung von Tipuliden. Entom. nachr., 6: 67-68. 80. Putbus. I 880 .

Abstract of a paper published in the Tageblatt of the ${ }_{52} \mathrm{er}$ Versammluag deutscher naturforscher, pp. 232-233. Contains a few words about the Tipulidae of amber as compared with those living in N. A merica. 
Packard, A. S. Is Limulus an arachnid? Amer. nat., I6: 2S7-292. So. Philadelphia. IS82.

In answer to Lankester, attempts to prove that Limulus is a crustacean, chiefly from the discovery by Willemoes of a nauplius-stage in the development of an East Indian species; a discovery which he atterwards acknowledges to be false, p. $43^{6}$. See also Moseley in Vature, $25: 582$.

Peach, Benjamin N. See Geikie, A.

Pike, J. W. Preservation of fossil insects and plants on Mazon Creek. So. Salem. IS8I. pp. 5 . Proc. Amer. assoc. adv. sc., 29 : 520-524. So. Salent. I 88 I.

A sketch of the history of the formations at Mazon Creek, with a mention in most general terms of the animals and plants.

Planchon, Gustave. Étude des tufs de Montpellier au point de vue géologique et paléontologique. 4. [Montpellier.] I 364 .

Liot seen; according to Oustalet mention is made of Indusia.

Ponzi, Giuseppi. I fossile del Monte Vaticano. 4. Roma. I S76. pp. 37, tav. 3. Atti. r. accad. linc., (2), 3: 925-959, tav. 1-3. 4. Roma. 1876 .

Under the name of Hylobium tortonianum describes, $p$. to (932), and figurcs, pl. 1 , fig. 9 , borings in fossil pine from pliocene deposits.

Primaeval Scottish scorpions. The scotsman, no. I $1960, p .3$. fo. Edinburgh. I 881 .

An anonymous communication, of more than a column in length, based on Geikie's article in Nature, with special refereace to Mr. Peacli's discoveries.

Procaccini-Ricci, V. Lettera prima . . . sull'anatomia delle filliti sinigalliesi. Nuov. ann. sc. nat., I : 190-213, pl. 4.5. So. Bologna. $183^{8}$.

Refers, p. 210 , to a fossil insect which is figured with a leaf, pl. 5, fig. $\mathrm{t}$; no details are given, and the figure is unrecognizable.

Reuss, A. E. Geognostische skizzen aus Böhmen. I er theil: Die umgebungen von Teplitz und Bilin in beziehung auf ihre geognostischen verhältnisse; ein beitrag zur physiographie des böhmischen mittelgebirges; mit I karte und 9 tafeln. $8^{\circ}$. Leitmeritz. I840.

Not seen; according to Deichmuller this work contains reference on p. 143 to the occurrence of fossil insects at Bilin.

Reuss, A. E. Die geognostischen verhältnisse des Egerer bezirkes und des Ascher gebietes in Böhmen. Abhundl. k.k. geol. reichsanst., I : I-72, map. $4^{\circ}$. Wien. 1852 .

Mentions, p. 59, the occurrence of impressions of Coleoptera and Diptera, generally very indistinct, in the cyprismergel of Krottensee. An exception is noted in a single Dipteron, which is figured and which Kollar places near Penthetria.

Reuss, A. E. Die gegend zwischen Kommotau, Saaz, Raudnitz und Tetschen. Löschn., Beitr. balneol., 2. So. Prag. 1847.

Not seen ; according to Deichmïller, this article contains some reference on p. 46 to the occurrence of fossil insects in certain Bohemian localities.

Reuss, A. E., und von Meyer, C. E. H. Die tertiären süss wassergebilde des nördlichen Böhmen's und ihre fossilen thierreste. Palaeontogr., $2: 1-73, p l$. I-I 2. $4^{\circ}$. Cassel. I849-5I.

Contains Geognostische skizze der tertiären süsswasserschichten des nördlichien Böhmens, pp. $\mathrm{t}-\mathrm{\tau}$, by Reuss alone, in which are recorded the discovery of Coleoptera at Kutschen (p. 6), and of insects, principally Coleoptera, at Luschitz (p. 7).

Richter, Georg Gottfried. Gazophylacium mineralium oder Mineralienkabinet. 8\%. Leipzig. I 7 I9.

Not seen; said to corstain something on Oeningen insects. de Rouville, Paul. Géologie des environs de Montpellier. 1855 .

Not seen : gives, according to Oustalet, some notice of the remains in the incusial limestone.

van Roy, C. IV. Ansichten über entstehung und vorkommen des bernsteins, so wie praktische mittheilungen uber den werth und die behandlung desselben als handelswaare. $8^{\circ}$. Danzig. 1840 .

Not seen.

S. Fossil coleoptera. Hardw. sc. gossip, 1867: 233. So. London. IS67.

Describes finding four Coleoptera in a stratum of debituminised peat in a freestone quarry near Fifeness.

Samouelle, George. See Murchison, R. I.

Scheuchzer, J. J. Meteorologia et oryctographia helvetica; oder Beschreibung der lufft-geschichten, steinen, metallen, und anderen mineralien des Schweitzerlands, absonderlich auch der uberbliebselen der sündfluth. Ist der dritte oder eigentlich der sechste theil der Natur-geschichten des Schweizerlands. $4^{\circ}$. Zürich. I7Is. t. p., ff. 7 , pp. 336 , pl. (I9).

Insecta diluviana on p. 336 is a paragraph saying that while the author is acquainted with fossil insects he has seen none from Switzerland; quotes Langius.

Scheuchzer, J. J. Physique sacrée, ou histoire naturelle de la bible. Traduite du latin; enrichie de figures en taille douce, gravées par les soins de Jean-André Pfeffel. 8 vol. fo. Amsterdam. 1732I 737 .

Vol. i, tab. 53. figs. 23-25, p. 68, gives figures of a beetle and odonate larva from Oeningen. and an odonate from Verona, which Heer afterwards determines. Original edition not seen.

Scudder, S. H. The devonian insects of New Brunswick (supra).

Extended abstract (by H. A. Hagen) in Zoöl. jahresb., r880, ii : $183-$ r92. $8^{\circ}$. Leipzig. $188 \mathrm{r}$.

Translation: Die devonischen insekten von Neu-Braunschweig und ihre beziehungen zu den spätern und noch lebenden insekten. .Kosmos, 5: 217-223. $8^{\circ}$. Stuttgart. I 881.

A translation of the general conclusions, with an abstract of the other portions, and comments by the editor, Erust Krause.

Scudder, S. H. The tertiary lake basin of Florissant (supra).

EXTRACT: Insects of the amyzon shales of Colorado. Amer. nat., I6: I 59-160. $8^{\circ}$. Philadelphia. I882.

Quotes some of the general results obtained

REPRINT: with same title as original. Rep.U.S. geol. geogr. surv. terr., 1878: 271-293, map. 80. Washington. 1882 .

Contains considerable additions, especially in the Arachnida and Neuroptera, where comparisons are instituted with European and other American fossils.

Scudder, S. H. [Minor notices of fossil insects.] Psyche, 3:277-279. 40. Cambridge. 1882.

Exhibition at meetings of the Cambridge entomological club of a cast of the first paleozic insect ever found (p. 277), and of illustrations of the tertiary insects of North America (p. 278); as well as remarks on fossil species of Termes ( $p 278$ ); on some carboniferous insects, and on tertiary spiders from Florissant (p. 279).

Scudder, S. H. Archipolypoda, a subordinal type of spined myriapods from the carboniferous formation. Mem. Bost. soc. nat. hist., 3: 143-182, pl. 10-1 3, $4^{\circ}$. Boston. I882.

Discusses their relation to modern diplopods and monographs the known species, adding several new ones; tweive species are recognized, divided into four genera. The first plate contains a restoration of the largest species with ot'ler animais and plants of Mazon Creek. 
Scudder, S. H. A new carboniferous cockroach from Mazon Creek, Illinois. Proc. Bost. soc. nat. hist., 21 : $-8^{\circ}$. Boston. ISS2.

Describes Etoblattina mazona, the neuration of the wings of the two sides differing.

Smith, Frederick. See Zaddach, E. G.

Tournal. Tertiary of Arnissan.

Is said to bave published some reference to fossil insects in a work on the above subject. I have been unable to verify it.

Troost, G. See Ballenstedt, J. G. J.

Turpin, Pierre Jean François. Note sur le terrain qui contient le tripoli de Bilin, en Bohême, par M. Elie de Beaumont; suivie de l'examen des débris organiques que renferme une des couches de ce terrain, par M. Turpin. Comptes rendus acad. sc., 7 : 501-503. $4^{\circ}$. Paris. 1838 .

The Note de M. Turpin occupies pp. 502-503. Mention is made, $\mathrm{p}$ 502. of the leg of an insect "très probablement $d$ 'un Acarus," as found in the earth.

Walchner, Friedrich August. Darstellung der geologischen verhältnisse des süsswasser-mergels von Oeningen im badischen seekreis und seiner fossilen flora und fauna. $8^{\circ}$. Karlsruhe. 1850 .

Separately printed from his Handbuch der geognosie zum gebrauche bei seinen vorlesungen, und zum selbststudium, mit besonderer berücksichtigung der geognostischen verhältnisse des grossherzogthum Baden. $2^{\circ}$ auf. $8^{\circ}$. Karlsuhe. $1847^{-18} 5^{1}$. (pp. 956 et seq.) Neither seen.

Walchner, F. A. Darstellung der geologischen verhältnisse des mainzer tertiärbeckens und seiner fossilen fauna und flora. $8^{\circ}$. Carlsruhe. 1850 . pp. 75

Contains, p. 57, a list of insects referred to twelve genera, only two of the species receiving names, - Pbryganea mombachiana and $P$. Blumi.

Separately printed from his Handbuch der geognosie, etc., as above. $2^{\circ}$ auf. $8^{\circ}$. Karlsruhe. $1847^{-51}$
Walckenaer, Charles Athanase, baron et Gervais, Paul. Histoire naturelle des insectes. Aptères. 4 vol. and atlas of 52 plates. So. Paris. IS $37-$ I $S_{47}$. Tom. 3 ( I 844 ), 2 t. p., pp. S, 476 ; - tom. 4 (I847), 2 t. p., pp. I6, 623.

References to fossils, all at second hand, will be found in vol. 3 , pp. $6,70-72,84,128,288,449$; and vol. 4 , pp. $329-330$, $345,356,360$.

Waterhouse, C. O. See Owen, R.

Westwood, J. O. [Exhibition of a fossil beetle from Stonesfield.] Trans. ent. soc. Lond., 4, journ. of proc., $40.8^{\circ}$. London. I $\$_{41}$.

Regards the elytra figured by Buckland (pl. $4^{\prime \prime}$, figs. 4-9) as prionideous, not buprestideous.

Weyenbergh, H. Sur les chenilles fossiles. Pet. nouv. entom., no. 202, p. 253. 4\%. Paris. 1878 .

A note calling attention to the caterpillar of the jurassic Sphinx Suelleni previously described by lim.

** Ami Boué is said to have been the first (Fourn. geol., 3: 105) to have referred to the insects of Radoboj, but I have been unable to verify the reference; and John Ray is stated to have made some references to fossil insects on ${ }^{2}, 8$ and 92 of his Historia insectorum; but $\mathrm{I}$ have examined the work for such references unsuccessfully.

* Among the papers on fossil insects known to me to be shortly forthcoming are the following: By Dr. H. A. Hagen upon the Psocina of the amber, with a folding plate, in the Stett. entom. zeit.; by Mr. B. N. Peach, an illustrated memoir on the recently-discovered scorpions of the carboniferous rocks of Scotland, in the Trans. royal. soc. Edinb.; and bv myself illustrated papers on the carboniferous hexapods of Great Britain, and on two new types of carboniferous myriapods from Mazon Creek, in the Menioirs Bost. soc. Mat. hist.; an extract from the last, discussing the affinities of Palaeocampa, will appear in the Amer. journ. sc.

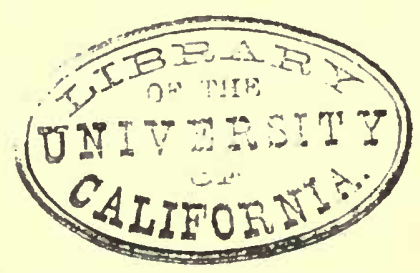






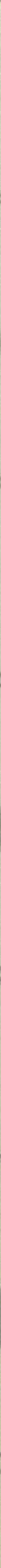


